OPEN ACCESS

Edited by: Robin Mesnage, King's College London, United Kingdom

Reviewed by:

Michael Nicolas Antoniou,

King's College London,

United Kingdom

Sofia Kottou,

National and Kapodistrian University

of Athens, Greece

Charles Benbrook

Benbrook Consulting Services,

United States

*Correspondence:

András Székács

a.szekacs@cfri.hu

Specialty section:

This article was submitted to

Environmental Health,

a section of the journal

Frontiers in Environmental Science

Received: 25 September 2017

Accepted: 26 June 2018

Published: 31 July 2018

Citation:

Székács A and Darvas B (2018)

Re-registration Challenges of Glyphosate in the European Union.

Front. Environ. Sci. 6:78.

doi: 10.3389/fenvs.2018.00078

\section{Re-registration Challenges of Glyphosate in the European Union}

\author{
András Székács ${ }^{1 \star}$ and Béla Darvas ${ }^{2}$ \\ ${ }^{1}$ Agro-Environmental Research Institute, National Agricultural Research and Innovation Centre, Budapest, Hungary, \\ ${ }^{2}$ Hungarian Society of Ecotoxicology, Budapest, Hungary
}

One of the most controversial societal issues today, regarding pesticide registration in the European Union (EU) may be the case surrounding re-registration of the active herbicide ingredient glyphosate. Shortly before the announcement of the conflicting views regarding the carcinogenicity status of this regulated agrochemical by EU Agencies, the European Food Safety Authority (EFSA) and the European Chemicals Agency (ECHA) on the one hand, and the International Agency for Research on Cancer (IARC) on the other hand, the Cancer Assessment Review Committee of the US Environmental Protection Agency (US EPA) also published re-evaluations. The US EPA assessment classified glyphosate into Group E, "not likely to be carcinogenic to humans." Similar positions were reached by EFSA and ECHA, assessing glyphosate as "unlikely to pose a carcinogenic hazard to humans" and "not classified as a carcinogen," respectively. A strongly opposing evaluation has previously been reached by IARC by classifying glyphosate into Group 2A, "probably carcinogenic to humans." IARC identified potential cancer hazards in this case, but did not estimate the level of risk it may present, which was taken into consideration by opposing agencies. Multiple effects of glyphosate have been reported, of which carcinogenic effects are only one component. Formulated glyphosate products-especially with polyethoxylated tallowamine and related compounds-have been shown to cause stronger cytotoxic or endocrine disrupting effects than the active ingredient glyphosate alone. Questions related to hazards and corresponding risks identified in relation to this active ingredient and its formulated herbicide preparations divide scientific circles and official health and environmental authorities and organizations, and touch upon fundamental aspects of risk assessment and product regulation. The decision has to consider both hazard-based (IARC) and risk-based analysis (EFSA); the former may not be suitable to calculate practical significances, and the latter being challenged if exposure estimations are uncertain in light of new data on residue levels. The results of current analytical surveys on surface water are particularly worrisome. In turn, the precautionary principle appears to be the optimal approach in this case for regulation in the EU.

Keywords: glyphosate, plant protection products, formulating agents, polyethoxylated tallowamine, hazard identification, risk assessment 


\section{INTRODUCTION}

Since its introduction as an herbicide active ingredient in 1971 (Baird et al., 1971), glyphosate [ $N$-(phosphonomethyl)glycine] became and remains the market leading herbicide active ingredient worldwide (Dill et al., 2010; Székács and Darvas, 2012; Benbrook, 2016). Its initial patent protection commenced in 1971 (Franz, 1974), and was renewed in the eighties on the basis of novel composition-through a process that involved property acquisitions among major pesticide companies. However, even this extended patent protection eventually expired, and glyphosate became a generic compound in 1991 in many parts of the world outside the United States (US), and even the US patent expired in 2000. The introduction of glyphosate-tolerant (GT), genetically modified (GM) crops, began in the US in 1996 and gave a further protected status and market boost to glyphosate, securing its market leading position ever since.

Nonetheless, not only the intellectual property rights, but also the legal authorization of any given pesticide active ingredient has to be periodically renewed by national or international authorities in different parts of the world, when the substance is intended to be applied in agriculture. In the European Union (EU), the re-registration of glyphosate was scheduled for 2013, and Germany was chosen as Rapporteur country, with Slovakia as co-Rapporteur. Re-registration of the compound received prominent attention, due to significant commercial interests and also environmental and health concerns.

The applied formulations may contain various additives (e.g., surfactants), besides the active ingredients, and these additives have long been classified as being inert or inactive components in relation to the main biological effects of the formulation. Such "inertness" is consequent by definition, as any component exerting the main biological effect would be considered an active ingredient, not an additive. However, these inert ingredients may be biologically or chemically active in their side-effect profile,

Abbreviations: AChE, acetylcholinesterase; ACS, American Chemical Society; ADI, acceptable daily intake; AMPA, aminomethyl phosphonic acid; ARfD, acute reference dose; BfR, German Federal Risk Assessment Institute, BVL, German Federal Office for Consumer Protection and Food Safety; CRP, Co-operative Research Programmes; DNA, desoxyribonucleic acid; EC, European Commission; ECHA, European Chemicals Agency; EEC, European Economic Community; EFSA, European Food Safety Authority; ELISA, enzyme-linked immunosorbent assay; ERD, enforcement residue definition; EU, European Union; FAO, Food and Agriculture Organization; GAT, glyphosate acetyltransferase; GM, genetically modified; GM38, human fibroblast cell line; GOX, glyphosate oxidoreductase; GT, glyphosate-tolerant; HEK293, human embryonic kidney cell line; HeLa, human cervical cancer cell line; HepG2, human hepatoma cell line; HT, herbicidetolerant; HT1080, human fibrosarcoma cell line; HUVEC, primary neonate human umbilical vein endothelial cell line; IARC, International Agency for Research on Cancer; IPA salt, isopropylamine salt; IPA, isopropylamine, isopropylammonium; JEG3, human choriocarcinoma cell line; JAr, human chorioplacental cell line; JMPR, Joint Meeting on Pesticide Residues; LC-MS/MS, liquid chromatography coupled to tandem mass spectrometry; MS, Member State; NE-4C, murine neuroectodermal stem cell-like cell line; NOAEL, no observable adverse effect level; OECD, Organisation for Economic Co-operation and Development; PAN, Pesticide Action Network; POEA, polyethoxylated tallowamine; PPP, plant protection product; RR, Roundup Ready ${ }^{\circledR}$; T47D-KBluc, human transfected estrogen-dependent breast adenocarcinoma cell line; UF, uncertainty factor; US EPA, US Environmental Protection Agency; US, United States (of America); WHO, World Health Organization. which also has to be considered in risk assessment and policymaking.

This survey attempts to summarize relevant data and information regarding decision-making in the re-registration process of glyphosate and its formulated herbicides, as well as main statements and events in evidence-based risk assessment that impacted it. It does not aim to justify or deny legislatory steps, but intends to reveal scientific data that had to be or should be considered in the corresponding decisions, with particular emphasis on results that have come to light since 2013, the preparation of the main risk assessment document on glyphosate, and with special attention to hazards identified in (eco)toxicity studies and to increased potential exposure levels corroborated by environmental monitoring of glyphosate residues.

\section{THE WORLDWIDE MARKET OF GLYPHOSATE}

Due to its patent protection, the market for glyphosate has been very favorable for the patent holder Monsanto Corporation for almost three decades. The leading glyphosate-based herbicide of Monsanto has been the Roundup group (Roundup Original ${ }^{\circledR}$, Roundup Classic ${ }^{\circledR}$ Roundup UltraMAX ${ }^{\circledR}$, Roundup WeatherMAX $\left.{ }^{\circledR}\right)$, containing mostly isopropylammonium (IPA) or potassium salts of glyphosate having excellent water solubility. Other salts are also used, of which ammonium and sodium salts have less water solubility, while the trimesium (trimethylsulfonium) or IPA salts are almost twice as water soluble as the already highly soluble potassium salt-in fact this physicochemical feature has been used in formulations and claimed as an innovative novelty during patenting. Expiration of the patent protection outside the US in 1991 caused a 30, 40, and $50 \%$ drop in the market sales of Roundup within 1, 2, and 5 years, respectively. However, the introduction of GT GM crops has more than compensated Monsanto for initial market losses, as Roundup could then continue to be exclusively marketed as a product linked to Roundup Ready ${ }^{\circledR}$ (RR) crops, the first GT crop being RR soybean in 1996, followed by GT cotton, GT maize, GT canola, GT alfalfa, and GT sugar beet (Dill et al., 2010).

Regardless of the position of Monsanto in patenting and marketing glyphosate, the worldwide market for the active ingredient is continuously increasing as depicted in Figure 1 on the basis of data reported (Bonny, 2011; Swanson et al., 2014; Benbrook, 2016). After average annual increases of $8 \%$ between 1982 and 1990, sales rose 16-fold in the 14 years between 1974 and 1990 (31\% annual growth) and 26-fold in the 15 years between 1990 and 2005 (44\% annual growth), and then maintained $8 \%$ annual growth between 2005 and 2014. The increasing boost after 1990 was clearly due to the worldwide introduction of GT crops, and this growth in consumption was further intensified with the expansion of the use of multiple trait (stacked genetic events) GM crops. Nonetheless, the use of glyphosate increased in regions without GM crop cultivation (due to pre-harvest or post-harvest chemical desiccation) as well: the overall consumption of glyphosate in Germany was boosted 5.7-fold between 1992 and 2012 (Berger et al., 2018). Thus, since 
2012 glyphosate alone represented globally a stable $12 \%$ of the overall pesticide market and $13 \%$ of the market for synthetic pesticides (BCC Research, 2012; Transparency Market Research, 2014, 2016).

In 2014-2015, glyphosate accounted for $26 \%$ of maize, $43 \%$ of soybean and $45 \%$ of cotton herbicide applications. Considering oral rat $\mathrm{LD}_{50}$ or 24 -month oral rat no observable adverse effect level (NOAEL) values for acute or chronic toxicity for all herbicide active ingredients used, glyphosate was estimated in a study (Kniss, 2017) to contribute only $0.1,0.3$, and $3.5 \%$ of the chronic toxicity hazard in those crops, respectively, on the basis of the hazard quotient approach weighting the hazard (toxicity) with the areas and dosages applied. Nonetheless, this estimation considered a factor termed "area-treatment" (instead of the absolute amounts applied), solely the average exposure (vs. exposure dynamics), and only of the active ingredients. Therefore, it did not take environmental fate, leaching toward drinking water supplies, ubiquitous exposures, side-effects by specific modes of action (genotoxic, hormonal, immunomodulant), as well as effects of the co-formulants into consideration. The study claims that increases in herbicide usage increased more rapidly on non-GM crops than on GM crops, and concludes that the replacement of glyphosate with other herbicides would be likely to result in increased chronic health risks to pesticide applicators. This strongly contradicts to earlier surveys (Heinemann et al., 2014; Benbrook, 2016; Perry et al., 2016), and is likely to be related to the fact that Kniss' study considered 159 herbicide formulations of 118 herbicide active ingredients, while herbicide-tolerant (HT) crops are designed against 8 herbicide active ingredients or active ingredient types (2,4-D, dicamba, glufosinate, glyphosate, oxynil type, sulfonylureas, imidazolinones, isoxaflutole), of which glyphosate by far is used most substantially in cultivation. Therefore, such an "overall" trend of all active ingredients considered, the vast majority of which not being related to HT crops is biased particularly for glyphosate, concealing the immense increases in glyphosate use in the grand average.

Overall production capacities have also risen over the decades. In 2012, the overall production capacity was 1.1 million tons/year which far exceeded the actual worldwide demand. Of the overall production, the Republic of China represents a substantial portion, and has increased its production capacity. Chinese production capacity was 323 thousand tons/year in 2007, but increased by 2.6-fold to 826 thousand tons/year in 2010, corresponding to a $37 \%$ annual increase rate. Statistics indicate that China alone is capable to meet the entire global glyphosate demand to date.

The success of glyphosate started with a predominant use of the active ingredient in the US in the seventies. Subsequently, the share of the US in the global annual turnover of glyphosate gradually decreased from $47 \%$ in 1974 to $15 \%$ in 2014 , as seen in Figure 2 on the basis of literature data (Benbrook, 2016). The decline of the US share has taken place more or less at a constant rate of $-0.6 \%$ /year, except for the period of $1990-$ 1995 , when a steep decline of $\sim-2.0 \%$ /year occurred, attributed to large increases in cultivation of GT crops in South America. The steep drop in 1991 also correlates with the expiration of the patent protection of glyphosate in different regions of the world (except for the US). The share of the US consumption may continue to decrease more rapidly as US consumption appeared to have leveled out after 2010 (reflected in a continuing decrease in the US share on the global consumption), while worldwide glyphosate consumption appeared to grow at an unchanged rate, partially due to GT crops gaining acreage in regions other than the US, and partially due to expanding glyphosate use in preor post-harvest crop desiccation. Globally, usage in GT crop cultivation and non-GT crop desiccation boosted the commercial success of glyphosate, while its manufacturing has shifted to Asia, resulting in a leading production role currently played by China.

\section{REGISTRATION OF GLYPHOSATE IN THE EUROPEAN UNION}

At the time of its introduction and following its approval in 1974, registration in 1983 and subsequent re-registration for use in cropland, forests, residential, and aquatic areas in 1993 by the US EPA (United States Environmental Protection Agency, 2016a), glyphosate had to be registered in Europe in each country, where it was intended to be marketed, and registration conditions and requirements varied by country. According to current patent laws, it was subjected to full product patent protection in Germany and other Common Market countries, while in the Soviet Bloc countries, where so-called "process patents" were in power, anyone could patent and register the active ingredient, who demonstrated by patent protection the invention of a novel chemical means for its synthesis.

A detailed and harmonized two-level registration system for plant protection products (PPPs) was introduced in the EU in 1991 with Council Directive 91/414/EEC (European Commission, 1991), specifying that pesticide active ingredients are regulated at EU level, managed by the European Commission (EC), while formulated pesticides are registered at Member State (MS) level. In addition, the new legal framework also requested re-registration of "old" active ingredients (already in use in the EU before 1991) (Klátyik et al., 2017a). Active ingredients subject to re-registration were specified in Annex I of the Directive, and the re-registration process was carried out in a four-stage work program completed by the end of 2010 (Anton et al., 2014). The first evaluation of glyphosate under Council Directive 91/414/EEC took place in 1995 within the first stage of the work program for existing active substances referred to in Article 8 (Dill et al., 2010). The basis of the evaluation was a joint dossier submitted by three industrial task forces, and Germany was designated as Rapporteur MS. Upon peer review of the documentation submitted, glyphosate was included in Annex I of Council Directive 91/414/EEC with Commission Directive 2001/99/EC (European Commission, 2001) coming into force in 2002. This authorization expired in 2012, when PPPs were already subject to Regulation 1107/2009 (European Commission, 2009) which came into force in 2011, and renewal of authorization of glyphosate under Regulation 540/2011 (European Commission, 2011b) was ordered. 


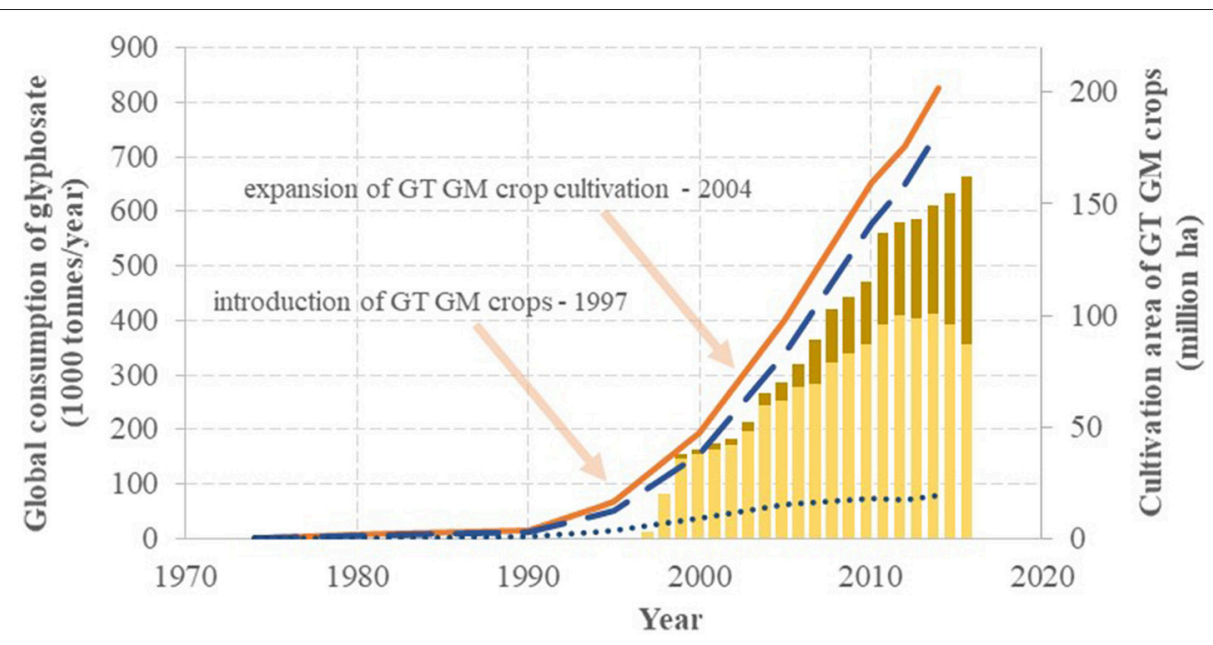

FIGURE 1 | The global annual turnover of glyphosate and the intensity of the cultivation of glyphosate-tolerant (GT) genetically modified (GM) crops: agricultural (slashed line), non-agricultural (dotted line) and overall (solid line) use of glyphosate, along with cultivation of single trait (light columns) and multiple traits (dark columns) GT GM crops. On the basis of Székács and Darvas (2012), Benbrook (2016), Cuhra et al. (2016), Myers et al. (2016) and the updated dataset of the International Service for the Acquisition of Agri-biotech Applications (James, 2015).

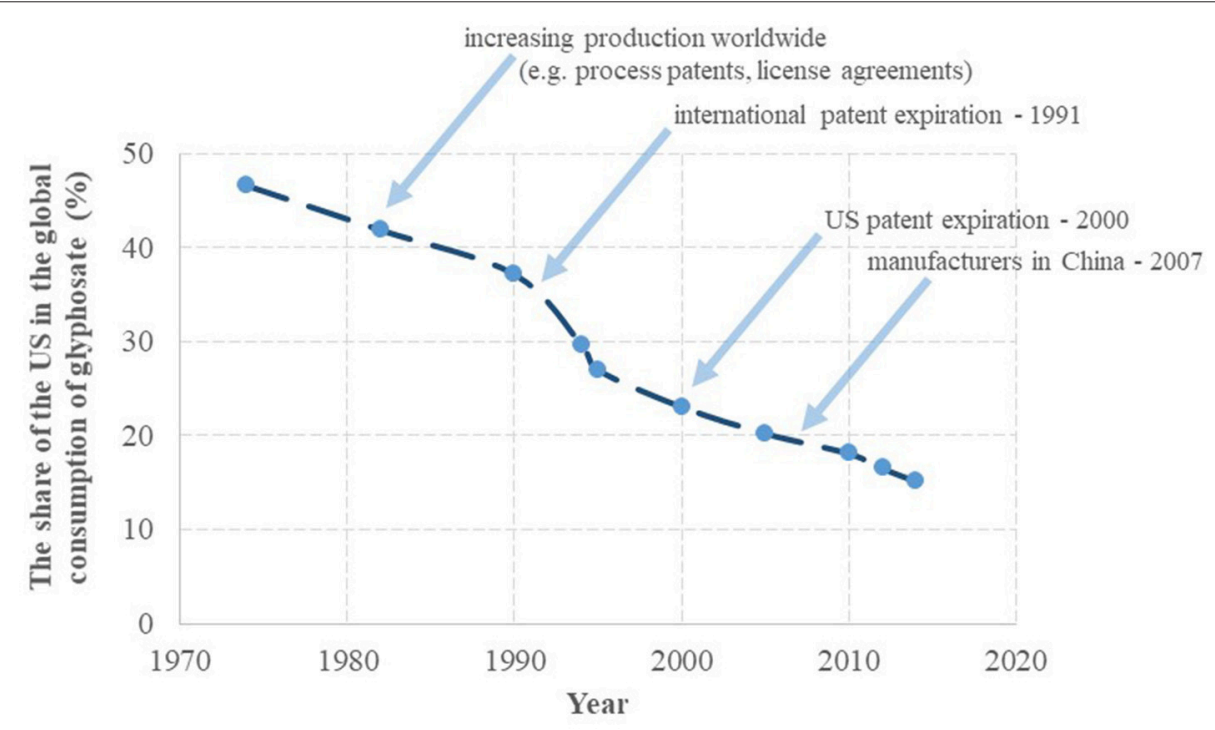

FIGURE 2 | The share of glyphosate uses in the United States from the global annual turnover. On the basis of Benbrook (2016).

The re-registration process took an unexpected turn that triggered wide public responses, when the renewal of the authorization of glyphosate, along with 38 other pesticide active ingredients, was postponed until 2015 (European Commission, 2010) and to be completed only in 2016. The reasoning for the postponement was related to delays in the overburdening task of pesticide authorization renewals. However, then more recent studies have indicated a range of potential harmful effects, including hepatotoxicity or hepatorenal effects on rats (Benedetti et al., 2004; Larsen et al., 2012), and the number of published studies increased by orders of magnitude e.g., publications related to glyphosate intoxication rose from 44 in
1978-1987 to 152 in 1996-2005 and to 875 in 2006-2015 (Zyoud et al., 2017). Although reviews of genotoxicity studies deemed DNA damage by glyphosate and glyphosate-based formulations secondary to cytotoxic effects (Kier and Kirkland, 2013; Kier, 2015), DNA-damaging effects and genotoxicity of glyphosate and particularly of its formulations (Roundup ${ }^{\circledR}$, Glyfos ${ }^{\circledR}$, Glyphogan ${ }^{\circledR}$, Glyphosate-Biocarb ${ }^{\circledR}$, etc.) on vertebrates (murine and human cells) (Bolognesi et al., 1997; Koller et al., 2012; Young et al., 2015; Townsend et al., 2017), cytotoxic effects of glyphosate-based herbicides on human embryonic and placental cells (Benachour et al., 2007; Benachour and Séralini, 2009; Gasnier et al., 2009, 2010; Mesnage et al., 2013a,b), indication 
of endocrine disrupting effects by showing activity on estrogen receptors in human hormone-dependent breast cancer cells (Thongprakaisang et al., 2013; Mesnage et al., 2017a), inhibition of the biosynthesis of testosterone and estradiol (Romano et al., 2010) and progesterone (Young et al., 2015) or inhibitory effects on aromatase, a key enzyme in steroid hormone biosynthesis (Cassault-Meyer et al., 2014; Defarge et al., 2016), teratogenic effects on vertebrates by inhibiting the retinoic acid signaling pathway (Lajmanovich et al., 2003; Paganelli et al., 2010; Carrasco, 2013), birth defects in rats (Guerrero Schimpf et al., 2017), and nephrotoxic and hepatotoxic effects of Roundup ${ }^{\circledR}$ have been demonstrated in rats in connection to RR GM maize (originally published in the journal Food and Chemical Toxicology in September 2012, but retracted by the journal in November 2013 following an alleged intervention from the industry stakeholder (Foucart, 2016), and subsequently republished in another journal a year later) (Séralini et al., 2014). The analysis of kidney and liver tissues from the same rats by molecular profiling (transcriptomics, proteomics, metabolomics) confirmed pathology of these organs in the lowest dose Roundup ${ }^{\circledR}$ treatment group culminating in non-alcoholic fatty liver disease (Mesnage et al., 2015a,b, 2017a,b).

The in vitro data on the cytotoxicity of glyphosate on various cell lines, as determined in the corresponding effective concentration values causing $50 \%$ mortality $\left(\mathrm{EC}_{50}\right)$, are shown in Figure 3, and range over two orders of magnitude (between 0.1 and $10 \mathrm{mg} / \mathrm{ml}$, corresponding to $\sim 0.5-50 \%$ of the dilution used in agricultural applications $\sim 2 \%$ ), with a very broad range in sensitivity among various cell lines tested. In general, the most sensitive cell lines appeared to be the human hematopoietic Epstein-Barr virus transformed lymphocyte Raji cells (Townsend et al., 2017), regenerative fin cell lines of fish origin (Qin et al., 2017), human epithelial HaCaT keratinocyte cells (ElieCaille et al., 2010; Heu et al., 2012a,b; Qin et al., 2017) and a murine neuroectodermal stem cell-like line, NE-4C (Székács et al., 2014). In contrast, cell types with the lowest apparent sensitivity were human choriocarcinoma cells (JEG3) (Benachour et al., 2007; Benachour and Séralini, 2009; Gasnier et al., 2009; Romano et al., 2010; Mesnage et al., 2013a), human chorioplacental cells (JAr) (Young et al., 2015), human hepatoma cells (HepG2) (Benachour et al., 2007; Benachour and Séralini, 2009; Gasnier et al., 2009, 2010), murine osteoblast precursor cells (MC3T3-E1) (Farkas et al., 2018), human embryonic kidney cells (HEK293) (Benachour et al., 2007; Benachour and Séralini, 2009; Gasnier et al., 2009; Mesnage et al., 2013a), and human primary neonate umbilical vein endothelial cells (HUVEC) (Benachour et al., 2007; Benachour and Séralini, 2009; Gasnier et al., 2009). Cytotoxicity has also been detected by other biochemical markers e.g., mitochondrial functions, release of lactate dehydrogenase, cell proliferation determined by the use of sulforhodamine B, or membrane integrity and lysosomal activities indicated by the uptake of neutral red dye (Koller et al., 2012; Defarge et al., 2016). The interaction of between glyphosate and mitochondrial succinate dehydrogenase has been verified by molecular modeling (Ugarte, 2014). The IPA salt of glyphosate was indicated to be genotoxic at concentrations of $0.16-1.6 \mu \mathrm{g} / \mathrm{ml}$ on human lymphocytes, fish erythrocytes and plant staminal nuclei in vitro and in vivo (Alvarez-Moya et al., 2014). Glyphosate has also been shown to be able to disrupt regenerative diploid (DIMF) and triploid fin cell lines from the Oriental weather loach (Misgurnus anguillicaudatus) with cytotoxicity of $\mathrm{LC}_{50}$ $=0.315$ and $0.372 \mathrm{mg} / \mathrm{ml}$, respectively. It also was found to induce DNA damage (micronucleus formation), cell damages (chromatin condensation, nucleus distortion, broken, and reduced endoplasmic reticulum, mitochondria and ribosomes) and apoptosis (Qin et al., 2017), intracellular oxidative cascade, morphological modifications, and apoptosis (Elie-Caille et al., 2010) caused by oxidative stress due to mitochondrial membrane potential disruption (Heu et al., 2012b) and cell morphological changes (Heu et al., 2012a). In addition to detection of decreased cell viability (tested in the above examples), cytotoxicity has been tested on other end points as well, including mutagenicity within the same range of toxicity $\left(\mathrm{EC}_{50}=0.6-0.9 \mathrm{mg} / \mathrm{ml}\right)$ for human epithelial type 2 cells (Hep-2) as occurs for human cervical cancer cell (HeLa) contaminant (Mañas et al., 2009), human fibroblast cells (GM38) (Monroy et al., 2005), and human fibrosarcoma cells (HT1080) (Monroy et al., 2005). Exposure of hippocampal pyramidal cells from rats to glyphosate at $2-6 \mathrm{mg} / \mathrm{ml}$ caused impaired neuronal differentiation and development and axon growth (Coullery et al., 2016), and a glyphosate absorption study across epithelial tissues e.g., across Caco-2 cells revealed saturable glyphosate uptake through epithelial transporter enzyme activity in an ATP- and $\mathrm{Na}^{+}$independent manner, not competed by specific amino acids or transporter inhibitors. Enhanced uptake into the epithelial cells at barrier mucosae has been pointed out to potentially result in more significant local and systemic effects than predicted from the passive permeability of glyphosate, and may lead to neural disposition and risk for brain-related toxicities (Xu et al., 2016). It has been indicated that glyphosate at concentrations of $0.09-1.69 \mathrm{mg} / \mathrm{ml}$ may induce DNA damage in leucocytes such as human peripheral blood mononuclear cells, cause DNA damage (single and double strand-breaks by the comet assay) and DNA methylation (global DNA methylation and methylation of p16 (CDKN2A) and p53 (TP53) promoter regions), and trigger DNA methylation in human cells (Kwiatkowska et al., 2017). Correlations were less apparent for other biochemical end points e.g., endocrine disrupting effects. Glyphosate was found to inhibit aromatases in JEG3 cells with $\mathrm{EC}_{50}$ values of $7 \mathrm{mg} / \mathrm{ml}$ (Richard et al., 2005), but causing $\sim 10 \%$ inhibition only at $0.024 \mathrm{mg} / \mathrm{ml}$ (Defarge et al., 2016). It has not been reported to exert estrogen agonist effects in the estrogen receptor activation-reporter assay on JEG3 cells, but was proven to be anti-androgenic at subagricultural and non-cytotoxic dilutions (Gasnier et al., 2009). In contrast, it has been indicated to exert estrogen receptor activation on human transfected estrogen-dependent breast adenocarcinoma cells (T47D-KBluc) with an $\mathrm{EC}_{50}$ value of $0.005 \mathrm{ng} / \mathrm{ml}$ (Thongprakaisang et al., 2013) or in a later study $0.002 \mathrm{mg} / \mathrm{ml}$ (Mesnage et al., 2017a), i.e., two orders of magnitude below concentrations causing cell mortality. Glyphosate-based herbicide preparations, containing polyethoxylated tallowamine (POEA) as formulating surfactant, showed a somewhat similar pattern at dilutions corresponding to two orders of magnitude lower glyphosate concentrations, (between 0.001 and $0.1 \mathrm{mg} / \mathrm{ml}$, 
corresponding to $\sim 0.005-5 \%$ of the dilution used in agricultural applications), with notable outstanding sensitivities for cell lines NE-4C and JAr. A study of exposure to glyphosate on human HepG2 cells using biomarkers of oxidative stress found prompt (upon $4 \mathrm{~h}$ ) elevated levels of permanent DNA damage (micronucleus formation) in cytokinesis-block micronucleus cytome assay and in alkaline comet assay (indicating a possible aneugenic effect), as well as decreases in lipid peroxidation, glutathione peroxidase activity and total antioxidant capacity at occupational exposure level $(0.0035 \mathrm{mg} / \mathrm{ml})$ revealing oxidative damage. In contrast, no significant effects remained upon $24 \mathrm{~h}$ of exposure in the levels of reactive oxygen species, glutathione and lipid peroxidation, indicating a certain ability of the cells to cope with prolonged exposure (Kašuba et al., 2017). Supported by an optical biosensor method and holographic microscopy, Roundup Classic ${ }^{\circledR}$ and glyphosate have recently been shown to inhibit normal cell adhesion of MC3T3-E1cells with $\mathrm{IC}_{50}$ values upon $1 \mathrm{~h}$ of exposure of 0.086 and $0.59 \mathrm{mg} / \mathrm{ml}$ in serum-containing medium and 0.10 and $1.97 \mathrm{mg} / \mathrm{ml}$ in serum-free conditions, respectively; and the approximately one order of magnitude higher inhibitory potency of Roundup Classic ${ }^{\circledR}$ was proven to be attributed to POEA (Farkas et al., 2018).

Substantially higher cytotoxicities recorded for glyphosatebased herbicide preparations at given dilutions than those seen for the corresponding glyphosate concentrations indicate that the excessive toxicity is clearly due either to component(s) in the formulation, or to their interaction with the active ingredient (see below). A problem occurring frequently in the scientific literature is, however, that reports do not always accurately specify the actual glyphosate formulation used, and often attribute the observed effect to the active ingredient, glyphosate. This is, in several cases, a wrong assumption, which can be verified only with the use of pure glyphosate. For this reason, comparative studies with glyphosate, co-formulants and formulations involved are of increasing significance (Klátyik et al., 2017a; Székács, 2017; Defarge et al., 2018; Mesnage and Antoniou, 2018).

Three glyphosate-based formulations, Roundup Express ${ }^{\circledR}$, Roundup Bioforce ${ }^{\circledR}$, Roundup GT ${ }^{\circledR}$ and Roundup GT Plus ${ }^{\circledR}$ at $5 \%$ dilutions corresponding to $0.04-2.3 \mathrm{mg} / \mathrm{ml}$ concentrations of glyphosate showed $22-97 \%$ inhibition of the mitochondial activity and activation of caspase 3/7 enzymes of HepG2 cells, while such levels of inhibition with glyphosate alone could be achieved only at or above $20 \mathrm{mg} / \mathrm{ml}$ concentration (Benachour et al., 2007; Benachour and Séralini, 2009; Gasnier et al., 2009; Mesnage et al., 2013a). Effects were similar, but even somewhat stronger on the more sensitive human Hep3G hepatic cell line (Gasnier et al., 2010). Roundup Bioforce ${ }^{\circledR}$, but not glyphosate, caused cytotoxicity through caspase 3/7 inhibition on testicular Leydig, Sertoli, and germ cells from rat and through adenylate cyclase activation on Leydig cells $\left(\mathrm{IC}_{50}\right.$ $=0.36-0.9 \mathrm{mg} / \mathrm{ml} ; 0.1-0.25 \%$ ) (Clair et al., 2012). Roundup Original ${ }^{\circledR}$ similarly induced calcium-mediated cell death in rat testis and Sertoli cells (de Liz Oliveira Cavalli et al., 2013). A study using a glyphosate-based herbicide formulation Glifosato Atanor ${ }^{\circledR}$ and spray adjuvant alkylphenol ethoxylate (Impacto ${ }^{\circledR}$ ) on the human Hep-2 cell line after $24 \mathrm{~h}$ of exposure indicated cytotoxicity due to oxidative damage by increased levels of reactive oxygen species with an $\mathrm{IC}_{50}$ value of 0.38 $\mathrm{mg} / \mathrm{ml}$ (corresponding to glyphosate concentration of 0.14 $\mathrm{mg} / \mathrm{ml}$ ) (Coalova et al., 2014), while glyphosate or its primary metabolite did not exert observable cytotoxicity in the test at concentrations up to $1 \mathrm{mg} / \mathrm{ml}$ (Chaufan et al., 2014). Addition of the spray adjuvant further reduced the $\mathrm{IC}_{50}$ value to 0.18 $\mathrm{mg} / \mathrm{ml}$ (corresponding to glyphosate concentration of 0.064 $\mathrm{mg} / \mathrm{ml}$ ). Vice versa, the glyphosate formulation also increased the toxicity of the spray formulant; i.e., the two substances showed synergistic cytotoxicity. The same formulation was shown to inhibit proliferation and differentiation of adipocyte 3T3-L1 fibroblasts (Martini et al., 2012) and to increase lipid peroxidation and antioxidant enzyme activity by oxidative stress, and to inhibit the expression of genes normally up-regulated during adipogenesis, e.g., master gene PPAR gamma (Martini et al., 2016a). Three glyphosate-based formulations showed cytotoxicity on adipocyte 3T3-L1 fibroblasts in the order of Roundup $\mathrm{FG}^{\circledR}>$ Glifosato Atanor ${ }^{\circledR}>$ Glifogran ${ }^{\circledR}$ in the range of $\mathrm{IC}_{50}$ values corresponding to glyphosate concentrations of $2.5-63 \mu \mathrm{g} / \mathrm{ml}$, while glyphosate itself exerted an $\mathrm{IC}_{50}$ value of $3.5 \mathrm{mg} / \mathrm{ml}$ (Martini et al., 2016b). In addition, Glifosato Atanor ${ }^{\circledR}$ was found genotoxic, correlated with lipid peroxidation and DNA fragmentation effects, at concentrations of 9-26\% (corresponding to glyphosate concentrations of $0.038-0.113$ $\mathrm{mg} / \mathrm{ml}$ ) on human peripheral blood leukocyte cells (Barbosa et al., 2017). Roundup Original ${ }^{\circledR}$ was found cytotoxic to human adipose-derived mesenchymal stem cells with an $\mathrm{IC}_{50}$ value corresponding to glyphosate concentration of $43.0 \pm$ $1.7 \mu \mathrm{g} / \mathrm{ml}$, induced death by apoptosis and necrosis upon $24 \mathrm{~h}$ of exposure, and caused reduced alkaline phosphatase activity in cells induced to osteogenic differentiation (de Melo et al., 2018). Formulations containing glyphosate IPA salt, Roundup 3 Plus ${ }^{\circledR}$, Roundup Biovert ${ }^{\circledR}$, Amega ${ }^{\circledR}$, Cargly ${ }^{\circledR}$ and Cosmic ${ }^{\circledR}$, unlike glyphosate alone, were shown to affect cell proliferation in embryonic cells $360 \mathrm{~min}$ upon fertilization of the sea urchin Sphaerechinus granularis inducing a delay in entry into the Mphase in the cell cycle (Marc et al., 2002, 2004). A Roundup ${ }^{\circledR}$ formulation, but again not glyphosate, was shown to affect cell proliferation and steroid production, as dramatically decreased cell numbers, as well as estradiol and progesterone production were recorded in granulosa cells from beef heifer ovaries upon exposure to Roundup ${ }^{\circledR}$ at $0.01-0.30 \mathrm{mg} / \mathrm{ml}$ (corresponding to glyphosate concentrations of $0.0018-0.054 \mathrm{mg} / \mathrm{ml}$ ) (Perego et al., 2017). Roundup ${ }^{\circledR}$ inhibited the survival of human L-02 hepatocytes $\left(\mathrm{IC}_{50}=0.15 \mathrm{mg} / \mathrm{ml}\right.$, corresponding to glyphosate concentration of $0.062 \mathrm{mg} / \mathrm{ml}$ ) by inducing mitochondrial and DNA damage, changes in membrane integrity and permeability, inhibition of the antioxidant system, and thus, apoptosis (Luo et al., 2017). Roundup Transorb ${ }^{\circledR}$ exerted cytotoxicity on a zebrafish (Danio rerio) hepatocyte cell line ZF-L at concentrations as low as $0.068-0.27 \mu \mathrm{g} / \mathrm{ml}$ (corresponding to glyphosate concentrations of $0.033-0.13 \mu \mathrm{g} / \mathrm{ml}$ ), due mostly to lysosomal instability and inhibition of mitochondrial function, and slightly to impaired cell membrane integrity. Synergistic detrimental effects were observed when Roundup Transorb ${ }^{\circledR}$ was applied with an insecticide formulation (Furadan 350 


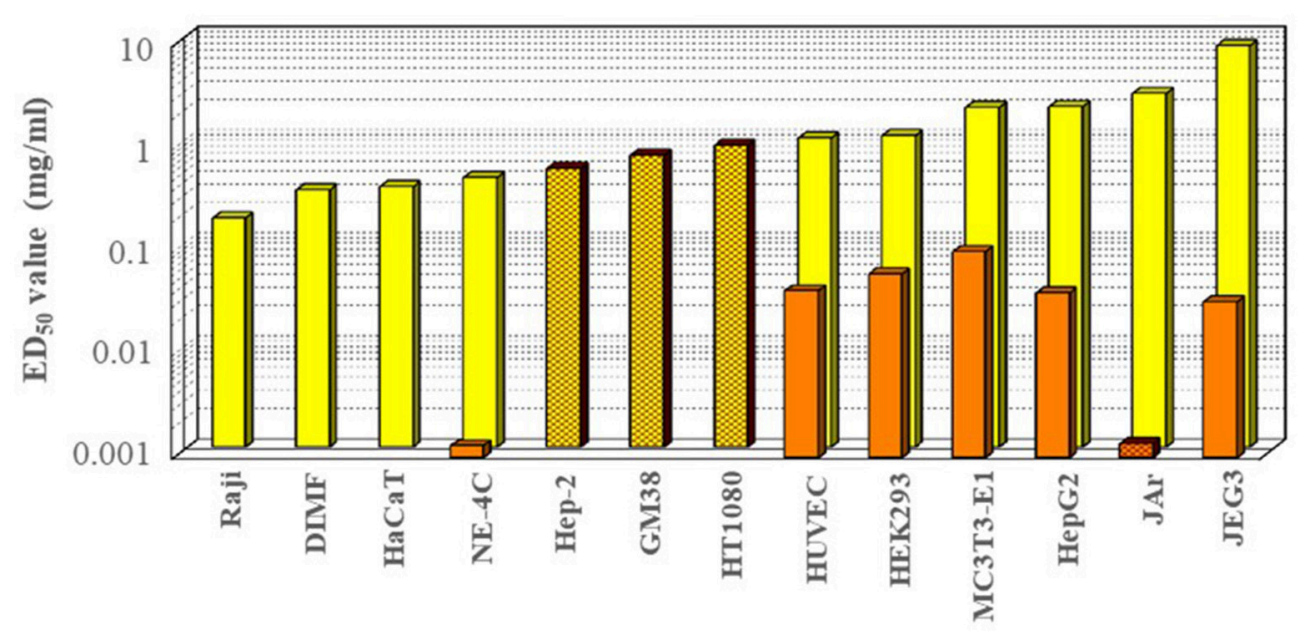

FIGURE 3 | In vitro cytotoxicity of glyphosate (light columns) and its formulated preparation Roundup ${ }^{\circledR}$ (dark columns) on various cell lines Raji: human hematopoietic Raji (Epstein-Barr virus transformed human lymphocyte) cells (Townsend et al., 2017), DIMF, diploid fin cell line from the Oriental weather loach Misgurnus anguillicaudatus (Qin et al., 2017); HaCaT, human epithelial keratinocyte cells (Elie-Caille et al., 2010); NE-4C, murine stem cell-like neuroectodermal cells (Székács et al., 2014); Hep-2, human epithelial type 2 (HeLa contaminant) cells (Mañas et al., 2009); GM38, human fibroblast cells (Monroy et al., 2005); HT1080, human fibrosarcoma cells (Monroy et al., 2005); HUVEC, primary neonate human umbilical vein endothelial cells (Benachour et al., 2007; Benachour and Séralini, 2009; Gasnier et al., 2009); HEK293, embryonic kidney cells (Benachour et al., 2007; Benachour and Séralini, 2009; Gasnier et al., 2009; Mesnage et al., 2013a); MC3T3-E1, murine osteoblast precursor cells (Farkas et al., 2018); HepG2, human hepatoma cells (Benachour et al., 2007; Benachour and Séralini, 2009; Gasnier et al., 2009); JAr, human chorioplacental cells (Young et al., 2015); JEG3, human choriocarcinoma cells (Benachour et al., 2007; Benachour and Séralini, 2009; Gasnier et al., 2009; Mesnage et al., 2013a, 2017a). Plain and grid column patterns indicate cytotoxicity detected by MTT test and mutagenicity tests, respectively.

$\left.S C^{\circledR}\right)$ of no known interaction between the active ingredients, indicating that toxicity was likely to be due to the surfactants in the commercial formulations (Goulart et al., 2015). Moreover, Roundup Full II ${ }^{\circledR}$ exerted acute toxicity $\left(\mathrm{LC}_{50}=0.009 \mathrm{mg} / \mathrm{ml}\right.$ upon $96 \mathrm{~h}$ of exposure) and genotoxic effects in blood, gill, and liver cells of the pacu fish (Piaractus mesopotamicus) determined in comet micronucleus and nuclear abnormalities assays (Leveroni et al., 2017). Roundup Transorb ${ }^{\circledR}$ was found mutagenic and genotoxic on gill erythrocyte cells of the guppy Poecilia reticulata (De Souza Filho et al., 2013), and a glyphosate-based herbicide at dilutions corresponding to glyphosate concentrations above $1.7 \mathrm{ng} / \mathrm{ml}$ caused significant decreases in the numbers of differentiated neuronal clusters and myotubes on primary embryonic stem cells from Drosophila melanogaster, being indicative of potential teratogenic effects (Argueta and Torres, 2017).

Upon clinical observations that surfactants used in glyphosate-based formulations substantially contributed to development of symptoms e.g., hypotension, mental deterioration, respiratory failure, acute kidney injury, and arrhythmia in intoxication cases by those formulations (Seok et al., 2011), targeted studies on surfactant-induced cellular effects found that cytotoxicity via apoptosis and necrosis caused by mitochondrial damage by surfactant POEA (TN-20) on mouse alveolar epithelial, fibroblast-like, and heart cell lines was reduced in the presence of glyphosate, while that of a corresponding polyoxyethylene lauryl amine ether (LN-10) surfactant was unaffected on alveolar cells, but increased on fibroblast-like and heart cell lines in the presence of glyphosate.
Glyphosate alone did not exert cytotoxicity at up to $0.17 \mathrm{mg} / \mathrm{ml}$ $(100 \mu \mathrm{M})$ (Song et al., 2012; Kim et al., 2013).

Moreover, the primary metabolite of glyphosate, aminomethyl phosphonic acid (AMPA) was found to be genotoxic on human and murine cell lines using the comet assay, the chromosome aberration test and the micronucleus test (Mañas et al., 2009). Assessing cytotoxicity of glyphosate, its metabolite AMPA and impurities ( $\mathrm{N}$-(phosphonomethyl) iminodiacetic acid, N-methylglyphosate, hydroxymethylphosphonic acid and bis-(phosphonomethyl)amine) on human peripheral blood mononuclear cells, found statistically significant decreases in their viability and ATP levels. Thus, N-methylglyphosate and bis-(phosphonomethyl)amine exerted cytotoxicity upon $24 \mathrm{~h}$ of exposure with $\mathrm{IC}_{50}$ values of $1.8 \mathrm{mg} / \mathrm{ml}$, AMPA showed significant but minor inhibitory effects at concentrations of $0.06-1.1 \mathrm{mg} / \mathrm{ml}$, while the others affected viability only slightly at concentrations of $0.48-1.7 \mathrm{mg} / \mathrm{ml}$, glyphosate itself being the least cytotoxic (Kwiatkowska et al., 2014, 2016). AMPA as photodegradation product of glyphosate was shown to cause high genotoxicity on Chinese hamster ovary cells (CHO-K1) (Roustan et al., 2014). In addition, the side-product of AMPA formation, glyoxylate was shown by activity-based protein profiling to be capable to react with cysteines across many proteins in mouse liver, inhibiting fatty acid oxidation and thus, increasing liver fat (Ford et al., 2017).

Consequently, reported in vivo effects of glyphosate and its formulated herbicide preparations are far more scattered than data from in vitro assays (Mesnage et al., 2015b). In vivo toxicity has been reported for a wide range of organisms of 
various phylogeny and with diverse symptoms (Gill et al., 2018). Glyphosate and even more its commercial formulations were indicated to induce DNA damage (micronucleus formation) in a wide range of animal species by numerous studies and a meta-analysis (Ghisi et al., 2016), moreover, the active ingredient was found to be genotoxic also in plants (Nardemir et al., 2015) and to induce oxidative stress and catalase activity in submerged macrophytes (Zhong et al., 2018). It has also been shown to serve as a source of phosphorous for algae at low concentrations (Klátyik et al., 2017b; Wang et al., 2017), and therefore, to potentially induce algal bloom (Drzyzga and Lipok, 2017). Formulated glyphosate-based herbicides, Touchdown ${ }^{\circledR}$ and Roundup ${ }^{\circledR}$ caused neurotoxicity (McVey et al., 2016) as well as locomotion and fertility inhibition (García-Espiñeira et al., 2018) on the nematode Caenorhabditis elegans. Following the results of the late Andrés Carrasco and his research group (Paganelli et al., 2010; Carrasco, 2013), recent findings in environmental toxicology of glyphosate and its formulated products include its revealed toxicity on amphibian species (Mann et al., 2009; Relyea and Jones, 2009; Meza-Joya et al., 2013; Wagner et al., 2013; Henao Muñoz et al., 2015; Baier et al., 2016a,b), on mollusks (Conners and Black, 2004) and on earthworms (Zaller et al., 2014; Gaupp-Berghausen et al., 2015). It affected hemocyte parameters and acetylcholinesterase (AChE) activity, but not antioxidant enzyme activities in mussel Mytilus galloprovincialis (Matozzo et al., 2018) with disruption of key biological processes including energy metabolism, $\mathrm{Ca}^{2+}$ homeostasis and endoplasmic reticulum stress response, as well as cell signaling identified by transcriptome analysis (Milan et al., 2018). Glyphosate exerted acute toxicity on the invasive snail Pomacea canaliculata with a $96-\mathrm{h} \mathrm{LC}_{50}$ value of $175 \mathrm{mg} / \mathrm{l}$, overly high for control purposes, but indicating oxidative stress, enhanced overall metabolic rate and altered catabolism from protein to carbohydrate/lipid mode (Xu et al., 2017).

Among organisms with life cycle related to water bodies, a glyphosate-based herbicide Factor $540^{\circledR}$ at exposures corresponding to glyphosate concentrations of $1-1000 \mu \mathrm{g} / \mathrm{l}$ modified structural and functional properties of freshwater phytoplankton communities (6 algal and 3 cyanobacterial species/strains) living in streams located in agricultural areas, causing a concentration-dependent reduction in chlorophyll-a and carotenoid levels, changes in the algal community structure, reduced diversity, as well as biochemical, and physiological parameters (shikimate content, lipid peroxidation, antioxidant activity of superoxide dismutase, catalase, and ascorbate peroxidase) (Smedbol et al., 2017, 2018). Roundup ${ }^{\circledR}$ was shown to be toxic to the food-borne trematode Echinostoma paraensei developing in given life stages in aquatic hosts (Monte et al., 2016). Roundup Express ${ }^{\circledR}$ and POEA were detected to exert toxicity on juveniles of the Pacific oyster Crassostrea gigas upon sub-chronic (35-day) exposure at concentrations of 0.1, 1 and $100 \mathrm{ng} / \mathrm{ml}$ (Mottier et al., 2013, 2014; Séguin et al., 2017). Roundup Original ${ }^{\circledR}$ exerted lethal and sub-lethal effects on the widely distributed in dipteran freshwater nematoceran fly Chironomus xanthus with a $48 \mathrm{~h} \mathrm{LC}_{50}$ corresponding to glyphosate concentration of $251.5 \mathrm{mg} / \mathrm{l}$, as well as reduced larval growth of and disturbed emergence of adults at lower concentrations (Ferreira-Junior et al., 2017), and it reduced the growth rate, the escape swimming speed and the fat storage also on the endangered damselfly Coenagrion pulchellum at a level corresponding to a glyphosate concentration of $2 \mathrm{mg} / \mathrm{l}$, which is likely to lead to negatively influence fitness, mortality by predation and population dynamics (Janssens and Stoks, 2017). As in the latter test Roundup systematically resulted in $25-100 \%$ higher effects than glyphosate at equivalent concentrations, the enhanced effect was attributed to POEA. Toxicity to the water flea (Daphnia magna) is of special importance, and not only formulated glyphosate-based herbicides (Cuhra et al., 2013; Ørsted and Roslev, 2015), but also glyphosate residues in GT soybean (Cuhra et al., 2015) were shown to exert toxicity on this standard ecotoxicity indicator organism. Effects of glyphosate on somatic and ovarian growth, as well as of glyphosatebased formulations on ovarian growth and immune status of freshwater and estuarine crab species were reported (Hong et al., 2017; Avigliano et al., 2018; Canosa et al., 2018). Toxicities have extensively been reported for fish, including the zebrafish $D$. rerio, on which both glyphosate (Armiliato et al., 2014; Lopes et al., 2014; Uren Webster et al., 2014) and its formulated products (Bridi et al., 2017; Sulukan et al., 2017) were found to exert acute toxicity through inhibited carbonic anhydrase activity due to oxidative stress (production of reactive oxygen species), cellular apoptosis, effects on locomotor activity and aversive behavior, as well as reproduction disorders, deteriorating sperm quality, embryotoxicity malformations, and other endocrine disruption symptoms. Another study found carp (Cyprinus carpio) more sensitive to embryotoxicity of glyphosate at high concentrations (50 mg/l) than zebrafish (Fiorino et al., 2018). Glyphosate and AMPA were found toxic to guppies Poecilia reticulata (Antunes et al., 2017) with median lethal concentrations $\left(\mathrm{LC}_{50}\right)$ for $96-\mathrm{h}$ exposure of 0.07 and $0.16-0.18 \mathrm{mg} / \mathrm{ml}$, respectively, with tissue- and gender-specific histopathological responses at sublethal concentrations. Formulated glyphosate preparations (Roundup ${ }^{\circledR}$, Roundup Transorb ${ }^{\circledR}$ ) exerted even stronger toxicity to this and related guppy species (De Souza Filho et al., 2013; Harayashiki et al., 2013; Rocha et al., 2015; dos Santos et al., 2017) with exposure-time dependent hepatic histopathological damage (dos Santos et al., 2017) or genotoxicity (De Souza Filho et al., 2013). Roundup ${ }^{\circledR}$ was shown to affect hematological response and tissue AChE activity in carp (C. carpio) (GholamiSeyedkolaei et al., 2013; Kondera et al., 2018), increased glycogen and triacylglycerol consumption and lipid deposition in the liver, as well as changes in muscle glycogen in catfish (Rhamdia quelen) (Persch et al., 2018), DNA strand breaks in the goldfish (Carassius auratus) (Çavas and Könen, 2007; Lushchak et al., 2009; Li et al., 2017). Cytotoxicity by oxidative stress by Roundup ${ }^{\circledR}$ has been shown by transcriptomic profiling in carp and zebrafish (Uren Webster and Santos, 2015; Sulukan et al., 2017). Acute toxicity, harmful physiological effects including hepatotoxicity, neurotoxicity, deteriorated sperm counts, early life stage development and DNA-damaging effects have been reported for numerous other fish species as well for sublethal exposures to Roundup ${ }^{\circledR}$ products including Roundup Original ${ }^{\circledR}$, Roundup Transorb ${ }^{\circledR}$ and Roundup WG ${ }^{\circledR}$, Garlon ${ }^{\circledR}$, and other glyphosate-based herbicides (Soso et al., 2007; Cavalcante et al., 2008; Guilherme et al., 2010, 2014a,b; 
Modesto and Martinez, 2010; Shiogiri et al., 2012; Ghisi and Cestari, 2013; Nwani et al., 2013; Marques et al., 2014; Moreno et al., 2014; Navarro and Martinez, 2014; Richard et al., 2014; Sinhorin et al., 2014; Braz-Mota et al., 2015; Menéndez-Helman et al., 2015; Li et al., 2016; de Moura et al., 2017; Sánchez et al., 2017; Gonçalves et al., 2018; Zebral et al., 2018) or POEA (Yusof et al., 2014). Roundup ${ }^{\circledR}$ was found to disrupt $17 \beta$-estradiol and reduce glutathione concentration in the liver of the endangered fish species delta smelt (Hypomesus transpacificus) upon $6 \mathrm{~h}$ of exposure at levels corresponding to $78 \mu \mathrm{g} / \mathrm{l}$ glyphosate concentrations and above (Jin et al., 2018). As described earlier, effects of glyphosate and its formulated products on amphibians and mollusks (Conners and Black, 2004; Mann et al., 2009; Relyea and Jones, 2009; Paganelli et al., 2010; Carrasco, 2013; Meza-Joya et al., 2013; Wagner et al., 2013; Henao Muñoz et al., 2015; Baier et al., 2016a,b) received particular attention due to their known hormonal sensitivity. Differential toxicity of glyphosate and its formulated PPPs have been also considered in the official scientific opinion by EFSA on pesticide risk assessment for amphibians and reptiles (Ockleford et al., 2018). Identification of acute lethal, physiological and genotoxic effects of glyphosatebased herbicides, including Roundup Original ${ }^{\circledR}$ and Roundup Transorb $^{\circledR}$, have continued on amphibians (Lajmanovich et al., 2011, 2013, 2014; Yadav et al., 2013; Bellantuono et al., 2014; Levis and Johnson, 2015; Gandhi and Cecala, 2016; Rissoli et al., 2016; Soloneski et al., 2016) and reptiles (Latorre et al., 2013; Siroski et al., 2016). Teratogenic effects were reported in a treefrog (Scinax nasicus) (Lajmanovich et al., 2003) and in the embryo of the African clawed frog (Xenopus laevis) (Paganelli et al., 2010) in response to exposure to Glyfos ${ }^{\circledR}$ or Roundup Classic ${ }^{\circledR}$ at levels corresponding to 3-7.5 and 96-160 $\mathrm{mg} / \mathrm{l}$ glyphosate concentrations, respectively. Hepatotoxicity of glyphosate and Roundup Ultramax ${ }^{\circledR}$ was observed in tadpoles of the neotropical frog Leptodactylus latrans (Bach et al., 2018), but the formulated herbicide product was found 10-fold more toxic than glyphosate, leading to histopathologic lesions at a level corresponding to a glyphosate concentration of $0.37 \mathrm{mg} / \mathrm{l}$. Teratogenicity is not exclusively related to POEA, as a POEAfree micro-emulsion formulation containing polyethoxylated isotridecyletherpropylamine as a surfactant, Roundup ${ }^{\circledR}$ Power 2.0 has been found to exert embryotoxicty on X. laevis in the frog embryo teratogenesis assay-Xenopus (FETAX) with a $96-\mathrm{h} \mathrm{EC}_{50}$ value of $7.8 \mathrm{mg} / \mathrm{l}$, while glyphosate was not found to be embryolethal, only causing edemas at the highest concentration tested, $50 \mathrm{mg} / \mathrm{l}$ (Bonfanti et al., 2018). Toxic effects were correlated with the inhibition of degradative enzymes (esterases and glutathione S-transferase) (Lajmanovich et al., 2011, 2013, 2014), while teratogenic effects and malformations have been linked to inhibition of the retinoic acid signaling pathway (Paganelli et al., 2010; Carrasco, 2013). Other studies on amphibians indicated increased excretion of defensive chemicals in the common toads (Bufo bufo) upon exposure throughout larval development to Glyphogan Classic ${ }^{\circledR}$ (360 g/l glyphosate-the same composition as Roundup Classic ${ }^{\circledR}, 41.5$ $\mathrm{w} / \mathrm{w} \%$ glyphosate and $15.5 \mathrm{w} / \mathrm{w} \%$ POEA) at a level corresponding to $4 \mathrm{mg} / \mathrm{l}$ glyphosate concentration (Bókony et al., 2017; Miko Z. $S$ et al., 2017a) and behavioral changes of adult newts (Lissotriton vulgaris) in response to exposure to Glyphogan Classic ${ }^{\circledR}$ at levels corresponding to 2 and $6.5 \mathrm{mg} / \mathrm{l}$ glyphosate concentration (Mikó Z. et al., 2017b), even though the same research group previously reported no observable effects on L. vulgaris with Glyphogan Classic ${ }^{\circledR}$ at a final glyphosate concentration of $6.5 \mathrm{mg} / \mathrm{l}$ (Ujszegi et al., 2015, 2016). In artificial pond mesocosm experiments exposure to the generic glyphosate-based herbicide GLY-4 Plus affected mortality, body size, cellular immune response and tail morphology of the larvae of the spotted salamander Ambystoma maculatum in an UV-B radiation dependent manner (Levis and Johnson, 2015), and similar effects were observed on the blue ridge two-lined salamander Eurycea wilderae as well (Gandhi and Cecala, 2016). The exposure of wild-living amphibians present in agricultural fields was assessed to be increased in parallel to the 5.7 -fold increase of the overall consumption of glyphosate in German agriculture between 1992 and 2012 (Transparency Market Research, 2016). The formulated glyphosate-based herbicide $\mathrm{Clinic}^{\circledR}$ at a level corresponding to a glyphosate concentration of $30 \mathrm{mg} / \mathrm{l}$ at $96-\mathrm{h}$ exposure caused significant increases in the gene expression and activities of catalase, superoxide dismutase, and AChE in the freshwater turtle, the red-eared slider Trachemys scripta elegans and the Mediterranean pond turtle Mauremys leprosa, on the basis of which the herbicide is considered a threat to these turtle species (Héritier et al., 2017).

Among mammals, the highest toxicity has been reported on rats during a near life-long exposure (Séralini et al., 2014). A feeding experiment was carried out with Sprague-Dawley rats (55-day old at the beginning of the experiment) and substance (Roundup GT Plus ${ }^{\circledR}$ containing 450 g/l glyphosate IPA salt) administration ad libitum in drinking water through 2 years. The final three groups were fed with the control diet and had access to water supplemented with, respectively, $1.1 \times$ $10^{-8} \%$ of Roundup GT Plus ${ }^{\circledR}$ (100 ng/l, corresponding to $\sim 50 \mathrm{ng} / \mathrm{l}$ of glyphosate-a common contamination level of regular tap waters), $0.09 \%$ of Roundup GT Plus ${ }^{\circledR}$ [corresponding to $\sim 400 \mathrm{mg} / \mathrm{kg}$ of glyphosate-the US maximal residue limit (MRL) of glyphosate in GM feed], and $0.5 \%$ of Roundup GT Plus ${ }^{\circledR}$ (corresponding to $2.25 \mathrm{~g} / \mathrm{l}$ of glyphosate-half of the minimal agricultural working dilution). The highest tumorogenic activity was noted on day 600 in female rats treated at the lowest dose, i.e., the effect did not appear to increase with dose. As the numbers of rats used in the experiment were too few to constitute a definitive carcinogenicity study, it is only suggestive of a trend and possible outcome that needs to be repeated with a greater cohort of animals. In a study on Wistar rats treatment with glyphosate at 0.7 or 7 $\mathrm{mg} / \mathrm{l}$ ad libitum in the drinking water for 30 and 90 days, respectively, resulted in reduced glutathione and enhanced glutathione peroxidase levels in the liver, kidney and gut of the treated animals (Larsen et al., 2012), and similarly, when Wistar rats treated with $4.87,48.7$, or $487 \mathrm{mg} / \mathrm{kg}$ of Roundup (commercialized under the name GlyphosateBiocarb $^{\circledR}$ in Brazil), reduced alanine aminotransferase and aspartate aminotransferase levels were recorded in their liver (Benedetti et al., 2004). Roundup Transorb ${ }^{\circledR}$ administered to Wistar rats at $50 \mathrm{mg} / \mathrm{kg}$ body weight (b.w.) ad libitum in 
their drinking water given at $0.25 \mathrm{ml} / 100 \mathrm{~g}$ of b.w. caused a testosterone-disruptor effect (Romano et al., 2012). In addition, nephrotoxicity (Hamdaoui et al., 2016), hepatotoxicity (ElShenawy, 2009; Haskovic et al., 2016; Tang et al., 2017; Lozano et al., 2018), neurotoxicity on dopaminergic markers (Hernández-Plata et al., 2015; Martínez et al., 2018), and on the immature rat hippocampus (Cattani et al., 2014), effects on intestine peristalsis (Chłopecka et al., 2014, 2017), sperm quality (Abarikwu et al., 2015; Dai et al., 2016) and reproductive toxicity (Owagboriaye et al., 2017), estrogenic effects (Vandenberg et al., 2012; Varayoud et al., 2017) and the effect of neonatal exposure to female adult reproductive performance (Ingaramo et al., 2016, 2017) have been demonstrated. Liver dysfunction observed in rats correlated with gut microbiome disturbances identified in a recent study (Lozano et al., 2018): longterm effects of Roundup Grand Travaux Plus ${ }^{\circledR}$ at 3 doses (corresponding to glyphosate concentrations of $50 \mathrm{ng} / \mathrm{l}, 100 \mu \mathrm{g} / \mathrm{l}$, and $2.25 \mathrm{~g} / \mathrm{l}$ ) on the gut microbiota in Sprague-Dawley rats were observed by determining 141 bacteria families by highthroughput sequencing, of which alteration of the Firmicutes to Bacteroidetes ratio was recorded at different levels in females (but not in males). In contrast, another recent study using Glyfonova ${ }^{\circledR} 450$ Plus at doses corresponding to glyphosate concentrations of the established European Acceptable Daily Intake (ADI), $0.5 \mathrm{mg} / \mathrm{kg}$ body weight, found only limited shortterm effects on the gut bacterial community in Sprague Dawley rats (Nielsen et al., 2018), but warned that the effects can be more pronounced under malnutrition, when aromatic amino acids are less available. Repeated 4-week intranasal administration of Glifoglex ${ }^{\circledR}$ in male CF-1 mice ( $2 \mathrm{mg} /$ nostrils/day) affected the central nervous system (probably by altering neurotransmission pathways), caused neurobehavioral effects (by decreasing the ambulatory activity and increase in thigmotaxis, indicating higher anxiety levels), and impaired recognition memory as early as after $6 \mathrm{~h}$ (Baier et al., 2017). Results on hormonal effects of glyphosate-based herbicides on rats indicate modulation of the expression of estrogen-sensitive genes in the exposed animals with non-monotonic dose-response curves (Varayoud et al., 2017), indicating the need for hazard-based considerations in risk assessment (Vandenberg et al., 2012; Varayoud et al., 2017). A recent meta-analysis of eight previous studies on reproductive toxicity on males, carried out between 1992 and 2016, on sperm counts in rodents (Kunming and B6C3F mice and Sprague Dawley, Wistar and Fischer F344 rats) upon glyphosate administration at $40-50,000 \mathrm{mg} / \mathrm{kg}$ resulted in decreased sperm concentrations showing that glyphosatebased herbicides exerts reprotoxicity to male rodents. The effect, however, has erroneously attributed to glyphosate (Cai et al., 2017). Among mammals, significant increases in chromosome aberration (including chromatid breaks) frequencies and sister chromatid exchanges per cell were seen in large hairy armadillo Chaetophractus villosus peripheral blood lymphocytes upon treatment with Roundup Full $\mathrm{II}^{\circledR}$ at doses corresponding to glyphosate concentrations of $0.065-0.26 \mathrm{mg} / \mathrm{ml}$, confirming genotoxicity of the formulated glyphosate-based herbicide, evaluated by cellular and genetic biomarkers e.g., the mitotic index, cell proliferation kinetics, as well as frequencies of chromosome aberrations and sister chromatid exchanges (Luaces et al., 2017; Rossi et al., 2018).

Exposure to glyphosate during pregnancy has been indicated to significantly correlate with shortened pregnancy lengths in a cohort study in the US (Parvez et al., 2018). In addition, glyphosate has been potentially correlated with disruption of glycine homeostasis (Pérez-Torres et al., 2017) and pathological conditions e.g., autism (Nevison, 2014), fatal chronic kidney disease (in regions with heavy metal contamination in water) (Jayasumana et al., 2014, 2015), bronchial inflammation (Kumar et al., 2014), cardiovascular diseases (Gress et al., 2015), and cancer (Paumgartten, 2017). Dermatology problems upon skin contact with glyphosate-based herbicides have also been reported (Amerio et al., 2004; Heras-Mendaza et al., 2008; de Ávila et al., 2017; Elsner et al., 2018). A recent clinical study on the severity of cardiovascular effects due to poisoning with glyphosatebased herbicides attributed differential cardiovascular toxicity to the salt form (ammonium or IPA) of glyphosate used in the formulation (Moon et al., 2018), which in light of the toxicity data of the formulants used, may not be fully justified, as could easily be caused by differences in the formulant. Among environmental factors, glyphosate or its formulated products have been indicated to be linked with increased incidence of and mortality by multiple diseases (including cataract related to subsequent breast carcinoma) and cancer (Swanson et al., 2014; Singh et al., 2017). In the latter category, associations were found with non-Hodgkin lymphoma or multiple myeloma incidence (Hardell and Eriksson, 1999; McDuffie et al., 2001; Hardell et al., 2002; De Roos et al., 2003, 2005; Eriksson et al., 2008; Schinasi and Leon, 2014; Mesnage et al., 2015b), although other reviews claimed no causal relationship between exposure to glyphosate and lymphohematopoietic cancers (Acquavella et al., 2016; Chang and Delzell, 2016; Williams et al., 2016a). Some of these findings have been questioned by Monsanto (Acquavella et al., 1999) and a recent cohort prospective epidemiology study carried out in the US on 57310 licensed pesticide applicators and 32347 spouses in Iowa or North Carolina States found no apparent correlation between glyphosate use and solid tumor or lymphoid malignancies, including non-Hodgkin lymphoma, except for increased risk of acute myeloid leukemia in case of high exposure (Andreotti et al., 2018). Alleged attribution of certain chronic diseases (e.g., diabetes, neuropathies, obesity, asthma, infections, osteoporosis, infertility) to long-term exposure to glyphosate were judged unreasonable (Mesnage and Antoniou, 2017), but extremely low levels of a glyphosate-based herbicide (Roundup ${ }^{\circledR}$ ) have been shown in a multiomics study to possibly correlate to the development of metabolic syndrome, causing marked alterations of the liver proteome and metabolome revealing the presence of non-alcoholic fatty liver disease and its progression to non-alcoholic steatohepatosis (Mesnage et al., 2017b).

As glyphosate-based herbicides have been indicated to be associated with birth defects in the exposed population (Antoniou et al., 2011, 2012), the Pesticides Action Network (PAN) Europe and Greenpeace brought forward a lawsuit against the EC in connection to the postponement of authorization of glyphosate until 2015, based on the claim that they failed 
to properly consider the teratogenicity and cytotoxicity data in the risk assessment provided by the German Federal Office for Consumer Protection and Food Safety (BVL). Although the legal case has not been finalized to date, it has led to a decision by the Court of Justice of the EU that the EC has to make information on the release of PPPs into the environment accessible to any applicant requesting it, including the "identity" and the quantity of all of the impurities contained in the active substance, as well as the composition of the PPPs (InfoCuria, 2017). This is of particular importance, as in the previous policy the manufacturer had only to account for the technical purity of the active ingredient (i.e., unidentified technical impurities could be present in the product up to 5\%), and the exact chemical identity of the formulating agents could be handled as proprietary information.

The German Federal Risk Assessment Institute (BfR) compiled its Renewal Assessment Report on glyphosate at the end of 2013 (German Federal Institute for Risk Assessment, 2013), and expanded it in its voluminous (4,322 pages!) addendum (German Federal Institute for Risk Assessment, 2015) by 2015, on the basis of which the European Food Safety Authority published its peer review report (European Food Safety Authority, 2015b) and statement (European Food Safety Authority, 2015a). This report concluded that glyphosate is "unlikely to pose a carcinogenic hazard to humans." If accepted by the EU MSs, this verdict would allow immediate renewal of the authorization. However, in the meantime, after the BfR report, but prior to the EFSA statement, the International Agency for Research on Cancer (IARC), an expert organization of the World Health Organization (WHO), announced its evaluation on glyphosate (along with four other organophosphate active ingredients, diazinon, malathion, parathion and tetrachlorvinphos) in its periodical IARC Monographs (International Agency for Research on Cancer, 2015), and classified glyphosate in its Group 2A carcinogenicity category, "probably carcinogenic to humans." This classification has also been published in a leading medical periodical on this subject, Lancet Oncology (Guyton et al., 2015), and the full monograph was published recently (International Agency for Research on Cancer, 2017). The IARC classification is of particular importance for policy-making, because Regulation 1107/2009 on PPPs (European Commission, 2009) specifies strict conditions and restrictions for known or presumed human carcinogens and partly for suspected human carcinogens.

The diverging opinions among international risk assessment agencies EFSA and IARC has triggered a fierce debate in the scientific literature. A large team of researchers including 96 research professors from 22 countries worldwide (Portier et al., 2016) analyzed the data. Taking a contrary position were a set of six studies published in the journal Critical Reviews in Toxicology (Acquavella et al., 2016; Brusick et al., 2016; McClellan, 2016; Solomon, 2016; Williams et al., 2016a,b), sponsored by Monsanto and other members of the pesticide industry, as declared in the papers themselves. These reviews focused on the carcinogenicity, genotoxicity of glyphosate and exposures to it, but considered partly the same data and followed the same concept published in a previous risk assessment by the same lead author (Williams et al., 2000). Subsequently in 2016, the expert body Joint Meeting on Pesticide Residues (JMPR) of the Food and Agriculture Organization (FAO) and the WHO of the United Nations, including the FAO Panel of Experts on Pesticide Residues in Food and the Environment and the WHO Core Assessment Group on Pesticide Residues, discussed reevaluation of diazinon, glyphosate and malathion in the light of new studies that had become available since their last full assessments. The meeting concluded that glyphosate is "unlikely to pose a carcinogenic risk to humans from exposure through the diet" (Joint FAO/WHO Meeting on Pesticide Residues, 2016) a conclusion quite similar to the opinion of EFSA. To provide openness and transparency in the risk assessment process and to facilitate the public debate, as a part of its "Open EFSA" policy, EFSA has shared the raw data used in the EU safety evaluation of glyphosate (European Food Safety Authority, 2016). Moreover, in its additional position regarding risk assessment on the potential endocrine activity of glyphosate as a follow-up assessment to its previous conclusion in 2015, EFSA stated that glyphosate does not have endocrine disrupting properties through estrogen, androgen, thyroid, or steroidogenesis mode of action, based on a comprehensive toxicology database (European Food Safety Authority, 2017a). In connection to hazard identification, an IARC expert has stressed that causal relationships need to be empirically tested; prior assumptions may affect conclusions; and conflicts of interest have to be avoided (Saracci, 2016), another statement claimed that the IARC classification of glyphosate as a probable human carcinogen was the result of a flawed and incomplete summary of the experimental evidence (Tarone, 2018), while others voice the opinion that such accusations against IARC and its Monographs Program evaluation process are driven by economic interests, and are intimidating to IARC (Infante et al., 2018). The debate over glyphosate even caused the Netherlands to ban non-agricultural uses of glyphosate as of November, 2015, as well as a conflict between the EC and the European Parliament. The scientific background behind the risk assessment by EFSA and BfR was published in a research paper in 2017 (Tarazona et al., 2017a), and was immediately challenged and discussed in the same periodical (Portier et al., 2017; Tarazona et al., 2017b).

In June 2016, the EC extended the registration of glyphosate for 18 months. For this decision, an important factor, besides the ones discussed above, has been that the draft assessment by the European Chemicals Agency (ECHA) published in the meantime also concluded that there was no sufficient evidence to support a carcinogenicity hazard classification of glyphosate (European Chemicals Agency, 2017b). Public consultations were held over the summer of 2016, and ECHA, on the basis of the Harmonized Classification and Labeling Report (BAuA Federal Institute for Occupational Safety and Health, 2016) submitted by the German competent authority and other comments received during the public consultation, according to its statement in March 2017, endorsed that glyphosate was capable of causing serious eye damage and exerted toxicity to aquatic life with long-lasting effects, but concluded that it cannot be classified as a carcinogen, a mutagen or a reprotoxic compound on the basis of currently available scientific evidence (European Chemicals Agency, 2017a). Just as before regarding the opinions 
by EFSA or JMPR (AgroNews Scientists challenge EFSA claim of glyphosate safety, 2015; Nelsen, 2016), members of the Risk Assessment Committee of ECHA have also been accused of having competing financial interests leading them to a biased decision in favor of the re-registration of glyphosate (Johnston, 2017). In July 2017, the EC restarted negotiations with the MSs on the renewal of the approval of glyphosate with specific provisions regarding (a) protection of groundwater, as well as terrestrial animals and non-target plants; and (b) a ban of POEA as a formulating agent for glyphosate (see below). The aggregated economic impacts of a possible ban on glyphosate were assessed to be relatively small by a highly detailed, spatially explicit bio-economic model of silage maize production in Germany (Böcker et al., 2018). The debate remained unsuccessful until November 2017, when, upon the fourth revision of the EC proposal and Germany unexpectedly changing its position, the EC Appeal Committee reached a qualified majority in favor of the renewal the approval of glyphosate for 5 years (European Commission, 2011a) adopted by the EC in December 2017 (Erickson, 2017; European Commission, 2017). In retrospect, the Executive Director of EFSA warns not to entangle broader societal issues e.g., the role of modern agricultural practices and multinational biotech firms in our food supply with evidencebased risk assessment of regulated products (Url, 2018). Others express concern regarding the expertise used by the regulatory agencies to evaluate the safety of glyphosate and point out that toxicologists at Monsanto Corp. anticipated the carcinogenicity classification of glyphosate by IARC (Foucart and Horel, 2018; Infante et al., 2018).

In the meantime, focus has been gradually put on the issue of differential toxicity of glyphosate and its formulated herbicide preparations. It has been previously shown that pesticide formulations exert higher toxicity than their active ingredients alone. In a study on formulated herbicide, insecticide, and fungicide preparations (three PPPs in each group), French researchers (Mesnage et al., 2014) demonstrated an increased cytotoxicity of the formulations of herbicides Roundup GT Plus ${ }^{\circledR}$ (glyphosate), Matin EL ${ }^{\circledR}$ (isoproturon), and Starane $200^{\circledR}$ (fluroxypyr-meptyl), insecticides Pirimor $\mathrm{G}^{\circledR}$ (pirimicarb), Confidor $^{\circledR}$ (imidacloprid), and Polysect Ultra ${ }^{\circledR}$ (acetamiprid), as well as fungicides Maronee ${ }^{\circledR}$ (tebuconazole), Opus ${ }^{\circledR}$ (epoxiconazole), and Eyetak ${ }^{\circledR}$ (prochloraz). These formulations were shown to be 2-2,000 times more toxic on human cell lines (HepG2, HEK293, and JEG3), than their active ingredients (indicated in parentheses). The effects of elevated cytotoxicity were attributed to formulating surfactants POEA, alkyl-aryl sulfonates, docusate sodium, N,N-dimethyldecanamide, 1,2benzisothiazoline-3-one, and benzenesulfonic acid, as well as solvents naphtha, 1-methyl-2-pyrrolidinone, xylene, isobutanol, and ethanol. POEA derivatives refer to non-ionic surfactants as mixtures differing in their ethoxylation rate, originating from animal fats. These substances are principally used as formulation agents (Castro et al., 2014; Klátyik et al., 2017a) both as built-in and tank-mix adjuvants, for herbicides, especially for glyphosate, and previously for diquat. POEA is added to glyphosate to allow uptake of the water-soluble active ingredient across plant cells, affecting membrane transport and to reduce the wash-off effect after spray application. Less ethoxylated POEA products are used for emulsifying mineral oils, and as dispersants, stabilizers, sanitizers, and defoaming agents, industrial detergents, metal cleaners, textile dye-leveling agents, paper de-inking reagents, and drilling lubricants. Among a number of surfactants used in the formulation of PPPs (Table 1), POEA appears to be associated with highest toxicity concerns, particularly in of formulated glyphosate-based PPPs (Romano et al., 2010; Mesnage et al., 2013a; Székács et al., 2014; Farkas et al., 2018). Considering this unfavorable toxicity profile, particularly as related to aquatic toxicity (Prosser et al., 2017; Rodriguez-Gil et al., 2017a,b), cytotoxicity and also the assessment by EFSA (European Food Safety Authority, 2015c), the EC has recommended EU MSs in September, 2016 to exclude POEA as a co-formulant from the use in PPPs containing glyphosate (European Commission, 2016a,b). As a result, a number of glyphosate-based herbicides containing POEA as a formulant have been banned for use in Hungary (Table 2) (National Food Chain Safety Office, 2016) and in other EU MSs. A yet unrefined issue regarding the EC recommendation is, however, why the use of POEA is proposed to be restricted only in conjunction with glyphosate. If the toxicity parameters of a substance justify restrictions, those should apply to all uses of the given substance in formulations of any pesticide active ingredient (e.g., diquat, nicosulfuron, or others) or should be considered for other industrial applications as well.

As seen in Table 2, glyphosate-based PPPs containing POEA as a formulant can be found in all three approval categories, original, derived, or parallel trade authorization. As specified by EU Regulation 1107/2009 (European Commission, 2009) at an EU level and in a Ministerial Decree 89/2004 (Ministry of Agriculture Rural Development Hungary, 2009) in Hungary, original authorization is based on full documentation of the PPP, derived authorization applied to PPPs distributed under names other than trade names on the original authorization, and parallel trade permits to be obtained to PPPs authorized in other MSs. As seen, 11, 7, and 6 PPPs with original authorization, derived authorization, and parallel trade permits have been banned due to their POEA content. (Note that one product, Roundup Classic $^{\circledR}$, has been authorized both under original authorization and parallel trade permit).

\section{EFSA VS. IARC}

Shortly before the announcement of the conflicting views by EFSA and IARC (WHO) about glyphosate, the Cancer Assessment Review Committee of the US EPA also published a re-evaluation in 2015 (United States Environmental Protection Agency, 2015), followed by a more detailed assessment topic a year later (United States Environmental Protection Agency, 2016b). Their assessment classified glyphosate into Group E, not likely to be carcinogenic to humans. The Agrochemical Division of the American Chemical Society (ACS) dedicated an entire symposium to glyphosate during the 252nd Annual ACS Meeting in 2016, the presentations of which having been published recently (Duke, 2018). The 23 papers presented covered the history of glyphosate, plant glyphosate resistance management, its plant biology and societal issues, but not the toxicology 
TABLE 1 | Various types of surfactants used in pesticide formulations.

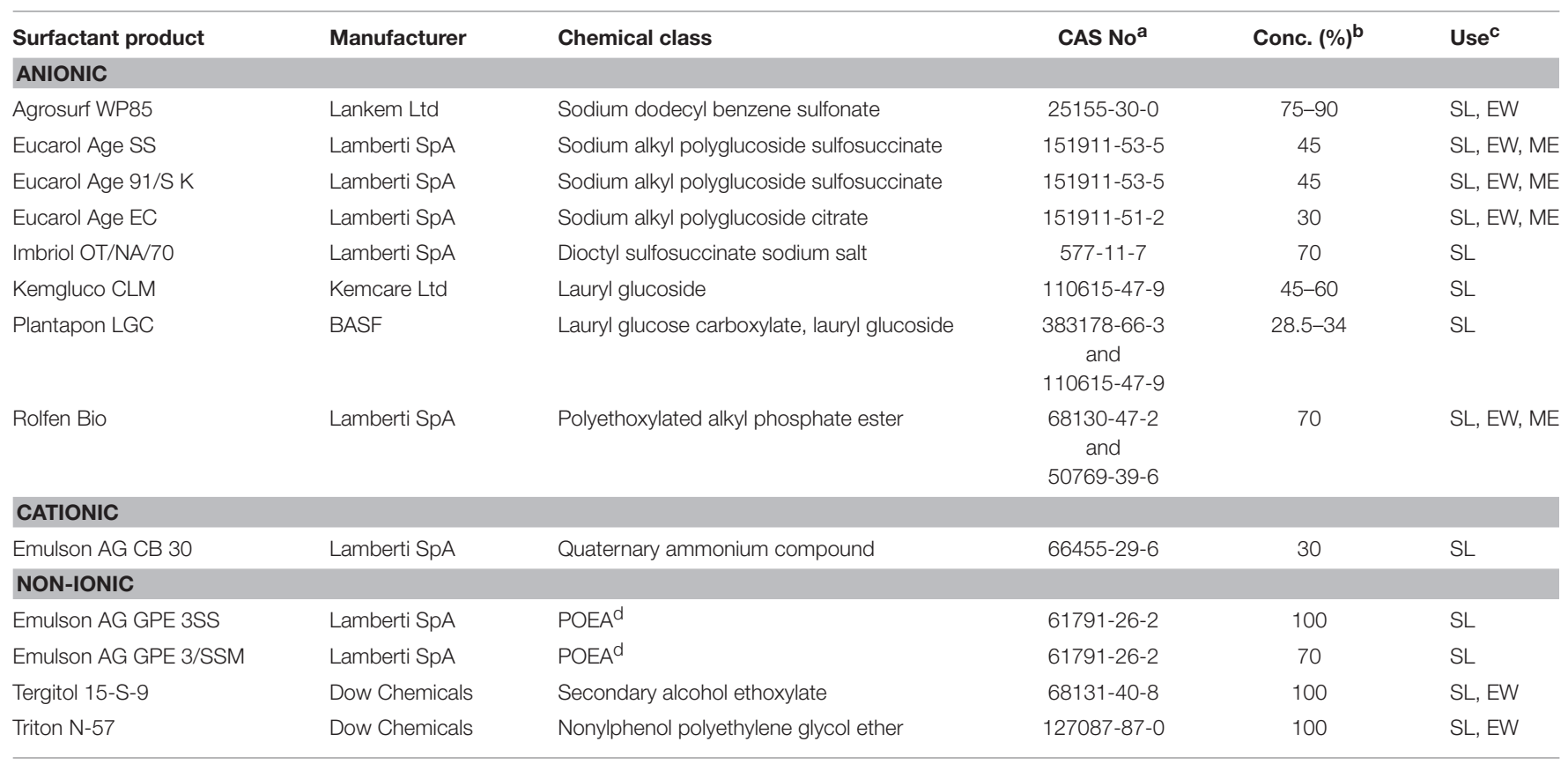

${ }^{a}$ Chemical Abstracts Registry Number.

${ }^{b}$ Percentage concentration ( $\left.w / w\right)$.

CSL: soluble liquid, EW: emulsion (oil in water), ME: microemulsion.

dPOEA: polyethoxylated tallowamine.

of the compound, reflecting the favorable evaluation by the US EPA. In contrast, agreeing with the IARC classification, California listed glyphosate as a known carcinogen on July 7 , 2017, under Proposition 65 law, which would require indicating this carcinogenicity hazard on the product label of glyphosatebased herbicide products. However, in response to a legal claim by an agricultural coalition including the National Association of Wheat Growers, Monsanto Corporation and farmer groups the U.S. District Court issued a preliminary injunction against this evaluation on the basis that the classification by IARC claims glyphosate only probably carcinogenic, while apparently all other regulatory and governmental bodies found the opposite, including the US EPA (Erickson, 2018). The positions of BfR, EFSA, JMPR, and ECHA were in accordance with the US EPA opinion, but the IARC evaluation (that followed the BfR statement, but preceded both EU Agency and FAO/WHO Agency statements, in chronology) was strongly opposed to it. It is worth noting that this has not been the only dramatic difference between classifications by IARC and the US EPA (see classification of lindane, 2,4-D and chlorothalonil).

Why is there a striking difference between statements by the US EPA, EFSA, ECHA, and JMPR on the one hand and IARC on the other hand? Why is it that while the formers concluded that glyphosate is unlikely to cause cancer, and suggested to increase its ADI value from 0.3 to 0.5 $\mathrm{mg} / \mathrm{kg}$ b.w./day within the EU, the latter have classified it as probably being carcinogenic to humans on the basis of limited evidence on humans and sufficient evidence on animals? Factors that resulted in these substantial differences between the opinions as stated by EFSA and IARC include: (a) The IARC evaluation is hazard-based, while EFSA is committed, by its legal mandate (European Parliament Council, 2002) to risk-based assessment. Risk-based assessment does not disclaim possible hazards, but assesses the likelihood of their actual occurrence under realistic scenarios. (b) The EFSA statement is restricted to the assessment of the active ingredient glyphosate, while IARC also considered reported effects of formulated herbicide preparations of practical importance. Within the latter approach, toxicity of tallowamine substances (e.g., POEA) used as formulants in PPPs has been well demonstrated and cannot be disregarded from the toxicology evaluation. (c) IARC based its assessment on peer reviewed publications in the scientific literature, while EFSA based its assessment also on non-public data from industry documentations submitted for the product approval into consideration. An analysis by PAN found that peer reviewed studies were dismissed by BfR and thus were not included in the EFSA assessment (Pesticide Action Network and Use of science in EU risk assessment, 2018). Indeed, the EFSA opinion does not cite any peer reviewed studies (European Food Safety Authority, 2015a). As a follow-up, a recent evaluation publication condemns the BfR, EFSA, and ECHA of violating current risk assessment guidelines, when dismissing 11 statistically significant cases of increased tumor incidences in two rat and five mouse studies, and claims that glyphosate should have been classified in the EU category 1B, 
TABLE 2 | Glyphosate-based herbicide formulations banned n Hungary, as of November 30, 2016, due to their content of polyethoxylated tallowamine (POEA).

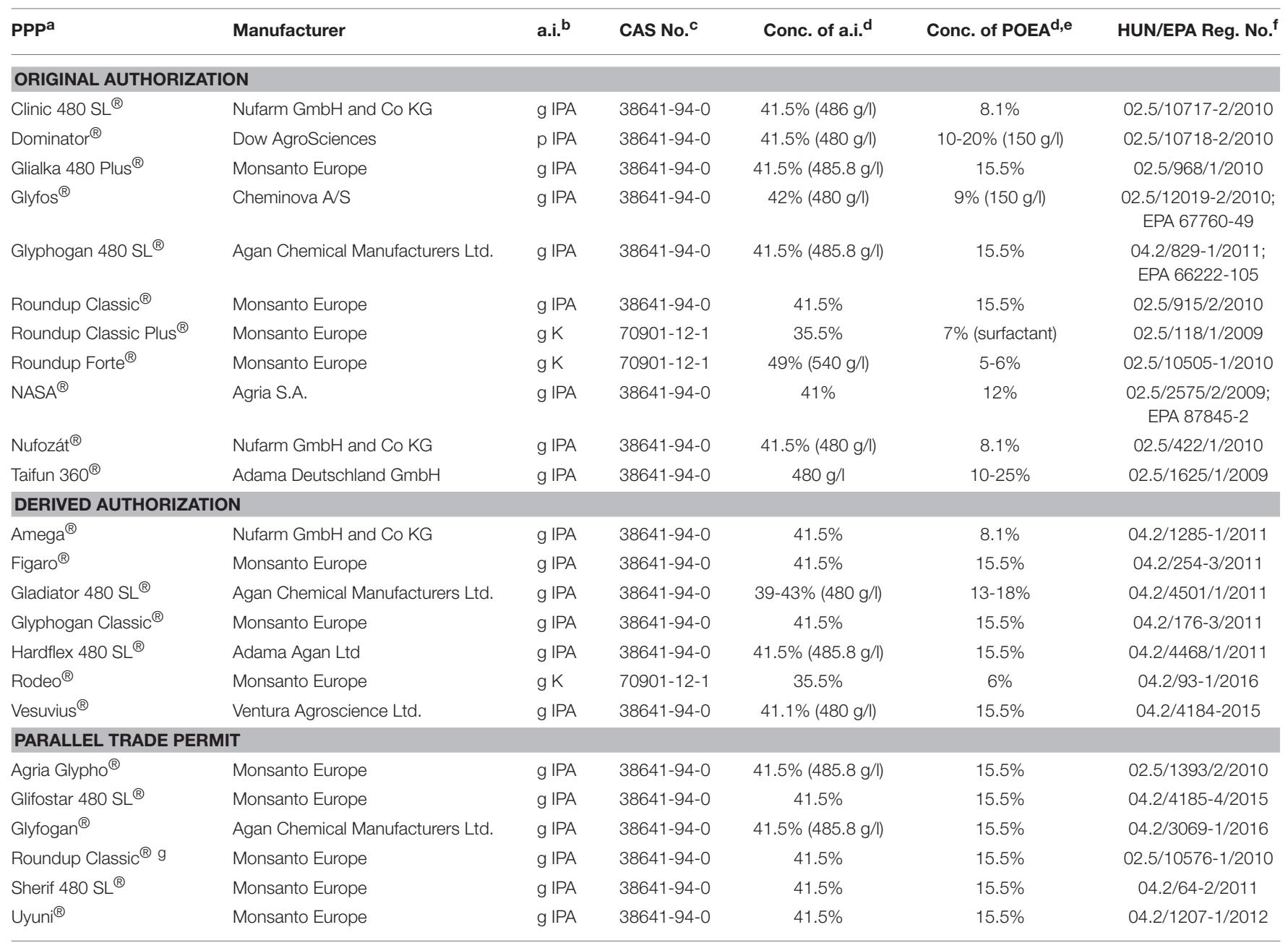

aPPP: plant protection product.

ba.i.: active ingredient; g IPA: glyphosate isopropylammonium salt; g K: glyphosate potassium salt.

${ }^{c}$ Chemical Abstracts Registry Number.

dPercentage concentration $(W / W)$, in some cases specified as $\mathrm{g} / \mathrm{l}$ as well.

ePOEA: polyethoxylated tallowamine.

${ }^{f}$ Hungarian Registration Number; US Environmental protection Agency (EPA) Registration Number.

gldentical to Roundup Classic ${ }^{\circledR}$ approved under original authorization, also permitted for parallel trade.

“presumed human carcinogen” (Clausing et al., 2018). EFSA, in the meantime, published its guidance document on uncertainty analysis (Benford et al., 2018) that considers possible omission of carcinogenicity data on the basis of genotoxicity/carcinogenicity margins of exposure, differences in the benchmark dose level due to unquantified uncertainties, the relevance and adverseness of the effects seen animals to humans, or misinterpretation of the probability of a given chemical having a carcinogenic mode of action as the probability cancer caused in an individual. It has to be noted that not only the German authority study (BAuA Federal Institute for Occupational Safety and Health, 2016), but also the evaluation by US EPA (United States Environmental Protection Agency, 2016b) covered these studies, and although admitting the occurrence of statistically significant differences, also disregarded them due to various considered reasons, including non-monotonic of flat dose response, effects deemed due to unusually low negative controls, no statistical significance in pairwise analyses or in multiple comparisons, effects concluded to be not compound-related, not always clearly apparent adenoma/carcinoma effects or no evidence of progression from adenomas to carcinomas, overly high dosages, or the presence of a viral infection within the colony tested.

Risks related to glyphosate may originate from increasing residue levels and incidence due to increased usage; and from modified residue composition due to the use of GT crops. Increasing use of glyphosate on GT crops and also as a crop desiccant on non-GT crops, and its subsequent release into the environment is seen both in increased residue levels found in environmental matrices, first of all drinking water (see below, Environmental and food analysis of glyphosate) and in more frequent occurrence reported, on the basis of which glyphosate and AMPA have been considered as ubiquitous surface water 
contaminants (Villeneuve et al., 2011; Székács and Darvas, 2012). These trends both increase risk through exposure. Thus, large increases in use in the EU, and even larger increase in exposures for citizens due to uses of GT crops have been evidenced (Myers et al., 2016). In addition, expanding applications of GT crops have modified residue composition: while a type of GT crops modified with a cp4-epsps gene achieves tolerance to glyphosate by expressing enolpyruvylshikimate-3-phosphate synthase (EPSPS) enzyme derived from Agrobacterium sp. strain CP4 not inhibited by glyphosate, other types of these GT plants modified with gox or gat genes provide tolerance to the compound by its enhanced degradation by transgenic metabolic enzymes, glyphosate oxidoreductase (GOX), or glyphosate acetyltransferase (GAT) expressed in the plant, leading to increased levels of the main metabolite AMPA (Székács and Darvas, 2012; Myers et al., 2016). Therefore, risk assessment has to consider such modified exposures to glyphosate and AMPA (Vandenberg et al., 2017) and other metabolites. Moreover, increasing occurrence of new metabolites has to be taken into account in the enforcement residue definiton (ERD) used for setting MRLs in various commodities and food products.

As risk assessments undertaken by government or government-related agencies concluded rather favorably for the re-registration of glyphosate, the ADI of glyphosate has been recommended by the BfR and endorsed by EFSA to be raised from 0.3 to $0.5 \mathrm{mg} / \mathrm{kg}$ b.w./day in the EU (European Food Safety Authority, 2015a). The new proposed ADI value was established on the basis of maternal and developmental NOAEL values of $50 \mathrm{mg} / \mathrm{kg}$ b.w./day from a developmental toxicity study in rabbits, considering the standard uncertainty factor (UF) of 100. If approved, the recommendation has several serious implications. On the one hand, it represents a significant (66\%) rise, which raises questions. Have our previous estimations on human exposure been improper to such extent, that the ADI can now be raised in spite of the increasing occurrence of glyphosate and AMPA in food, feed, drinking water, and the environment? Or is this rise simply a consequence of a technological issue: the increase of glyphosate residues due to excessive use on GM crops or as a pre-harvest desiccant? On the other hand, and probably even more importantly, the increase in ADI has consequences on future regulatory assessment. ADI is a crucial value in policy-making being a threshold level, below which no adverse effects are anticipated, and which already contains a 100-fold UF relative to the NOAEL. In consequence, doses below the ADI level are considered safe, and are not considered in regulatory assessments. However, several studies have indicated a range of toxic effects (hepatorenal and chronic toxicity below the ADI), which in this way skip the attention of the regulatory decision-maker. It is worth noting that while proposing an alleviation of the ADI as a part of the update of the toxicological profile of glyphosate, EFSA also proposed new, modified MRLs and ERD (see see below, Exposure to glyphosate - environmental and food analysis, human biomonitoring), and increased severity of the toxicity indices by setting, for the first time, an acute reference dose (ARfD) for the compound (European Food Safety Authority, 2015a). The reason for the ARfD has been severe toxicity and mortality seen in pregnant females in seven rabbit developmental toxicity studies, as well as post-implantation losses observed in two of those studies. It is noted that JMPR established an ADI of $1.0 \mathrm{mg} / \mathrm{kg}$ b.w./day for the sum of glyphosate, N-acetylglyphosate, AMPA and $\mathrm{N}$-acetyl-AMPA, and considered as unnecessary to set an ARfD (Food and Agriculture Organization of the United Nations, 2011).

It should also be noted that glyphosate and AMPA were proposed as lead compounds in the design of possible new anticancer drugs as well, due to their reported inhibitory effect on the proliferation and induction of apoptosis of cancer cells (while not affecting non-cancerous cells) (Li et al., 2013). The public debate is evidenced by a degree of outrage on both sides claiming short-sitedness, ignorance on one side (Zaruk, 2016) or conflicting interests or corruption of the evaluators on the other side (Burtscher-Schaden et al., 2017).

A recent GM technology development has been that Monsanto is extending the range of its Roundup Ready ${ }^{\circledR}$ crops toward older, potentially more toxic active ingredients e.g., dicamba (Roundup Ready 2 Xtend ${ }^{\circledR}$ crops) (Monsanto Corp, 2016). The prime driver of the technology is the wide scale presence of glyphosate-resistant weed species infesting agricultural fields in the US, and glyphosate by itself has failed as a stand-alone weed control agent. The Xtend ${ }^{\circledR}$ crops are not only glyphosate-tolerant, but also tolerant to dicamba. Thus glyphosate is not being replaced but being added to by systems such as Xtend ${ }^{\circledR}$.

\section{EXPOSURE TO \\ GLYPHOSATE-ENVIRONMENTAL AND FOOD ANALYSIS, HUMAN BIOMONITORING}

Glyphosate is a globally occurring pollutant in surface water due to its widespread use, good solubility $\left(11.6 \mathrm{~g} / \mathrm{l}\right.$ at $\left.25^{\circ} \mathrm{C}\right)$ and degradation (half-life time $\left(\mathrm{DT}_{50}\right)=28-91$ days, if photodegradation is excluded) in water (MacBean, 2012). Numerous surveys indicated residue levels between the limit of detection (LOD) of the analytical method used (e.g., 0.01 $\mu \mathrm{g} / \mathrm{l}$ ) and substantial concentrations (Table 3), with a striking difference between the Americas and Europe.

As pointed out earlier (Székács and Darvas, 2012), glyphosate and AMPA used to be detected in environmental studies previously less frequently due to the limited sensitivity of the traditional analytical methods based on gas chromatography. This has created an advantageous reputation for glyphosate of being environmentally benign. With the development of novel methods of increased sensitivity e.g., hyphenated techniques, such as liquid chromatography coupled to tandem mass spectrometry (LC-MS/MS) or immunoanalytical methods, such as enzyme-linked immunosorbent assays (ELISAs), and their subsequent wide availability for routine analysis, glyphosate residues have been detected at lower concentrations more frequently during the last two decades, than before, as also seen in the data listed in Table 3. Nonetheless, increasing research needs demand the development of advanced chemical 
TABLE 3 | Glyphosate residues found in surface and ground water in selected environmental monitoring studies.

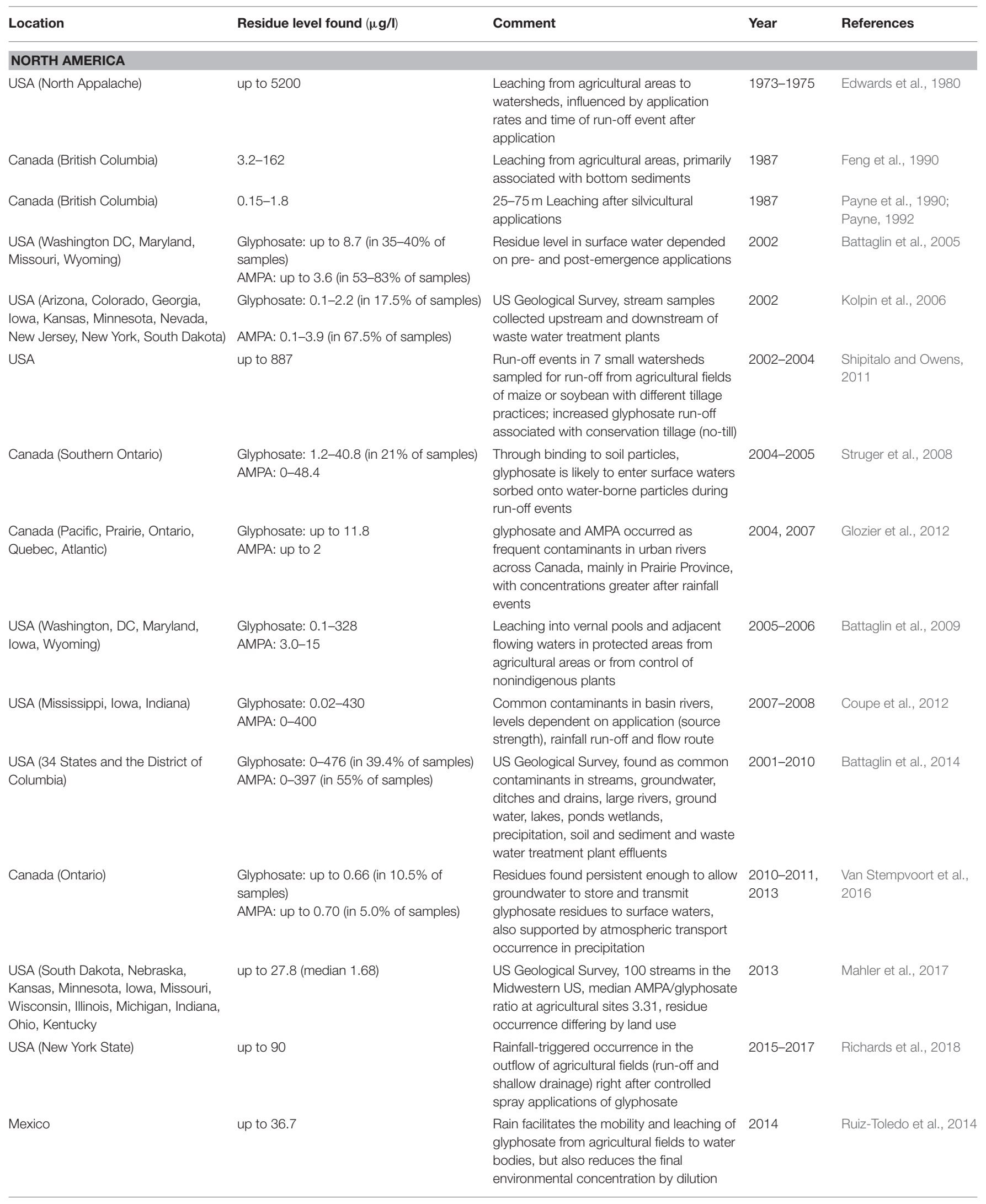


TABLE 3 | Continued

\begin{tabular}{ll}
\hline Location & Residue \\
\hline Mexico (Yucatan Peninsula) & up to 1.4 \\
Belize & $0.22-1.7$
\end{tabular}

\section{SOUTH AMERICA}

Argentina (Buenos Aires Province) 100-700

Argentina (Buenos Aires Province)

Glyphosate: up to 298

AMPA: up to 235

Argentina (Buenos Aires Province)

Argentina (Formosa, Chaco, Santa Fé, Buenos Aires, Entre Rios Provinces)

Argentina (Buenos Aires Province)

Argentina (Buenos Aires Province)

Argentina (Buenos Aires Province)

Brazil (Rio de Janeiro region)

ASIA

Malaysia

AUSTRALIA

Australia (Western Australia)
Glyphosate: 0-6.23

AMPA: 0.34-3.76
Glyphosate: up to 258 (in $69 \%$ of samples)

AMPA: up to 5865 (in $69 \%$ of samples)

Glyphosate: 0.2-1.8 (Galeguay River) up to 0.7 (in 15\% of samples) (Paraná River)

AMPA: 0.1-1.9 (Galeguay River)

$<0.3$ (Paraná River)

Glyphosate and AMPA: up to 0.5 (in 33 and $20 \%$ of samples, respectively)

(Quequén Grande River)

Glyphosate: up to 18.5 (in $78.9 \%$ of samples)

AMPA: up to 47.5 (in $96.5 \%$ of samples)

Glyphosate: up to 4.5 (in $>40 \%$ of samples)

AMPA: up to 0.9

Glyphosate: 2.6-10.1, AMPA < 0.1 (LOD) in surface water

glyphosate < 0.35 (LOD), AMPA < 0.1

(LOD) in ground water

\section{Comment}

Glyphosate found in $90 \%$ of groundwater samples evaluated

Residues found in phytotelmic water at seven sites near Maya Mountain Protected Areas

\section{Flow increased by rain caused the} transport of the herbicide from the direct area of influence to downstream sites

Glyphosate and AMPA are present in the soil of the agricultural basin (35-1502 and 299-2256 $\mu \mathrm{g} / \mathrm{kg}$, respectively), and reach surface water via surface run-off of soil particles

Surface stream, ground water sampled; the sampling site under urban-industrial land use had high concentrations in the spring (attributed to point pollution),

Higher levels in the middle- and lower-course tributaries of Paraná River in accordance with the intensive agriculture in those regions; pollutant adsorption on suspended matter

Glyphosate and AMPA were registered in almost all matrices at different sampling times (pre- and post-application events).

Glyphosate and AMPA predominated in surface water and sediment samples in the El Crespo stream

In shallow lakes in the Pampa region

Surface and ground water used for irrigation from the region of Rio de Janeiro tested

$\begin{array}{ll}\text { Year } & \text { References } \\ 2016 & \begin{array}{l}\text { Rendón-von Osten and } \\ \text { Dzul-Caamal, 2017 } \\ \text { Kaiser, 2011 }\end{array} \\ 2006-2007 & \text { Peruzzo et al., 2008 } \\ 2004 & \text { Aparicio et al., 2013 }\end{array}$

2010-2013 Caprile et al., 2017

2011-2012 Ronco et al., 2016

2012-2013 Lupi et al., 2015

2014-2015 Pérez et al., 2017

2015 Castro Berman et al., 2018

2017 Pinto et al., 2018
Higher glyphosate and AMPA

concentrations detected in surface water near oil palm plantation area

\section{1-2012 Mardiana-Jansar and} Ismail, 2014
Glyphosate is by far the most widely used 1995 pesticide in Australia; it is considered as a pesticide active ingredient with intermediate persistence; the use of Roundup Ready ${ }^{\circledR}$ crops may result in substitution of low volumes of sulfonyl urea and other herbicides with high volumes of Glyphosate

Substantial off-site herbicide movement from irrigated sugarcane farms
Australian Academy of Technological Sciences, and Engineering, 2002

Australia (Queensland)

up to 54

\section{fromirigated sugarcane farms}

Glyphosate occurred in surface water due

to weed control application in rail tracks as

one of the main sources

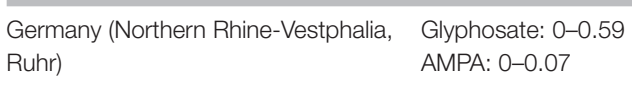

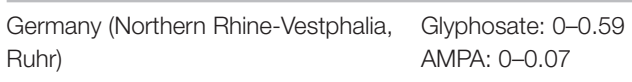


TABLE 3 | Continued

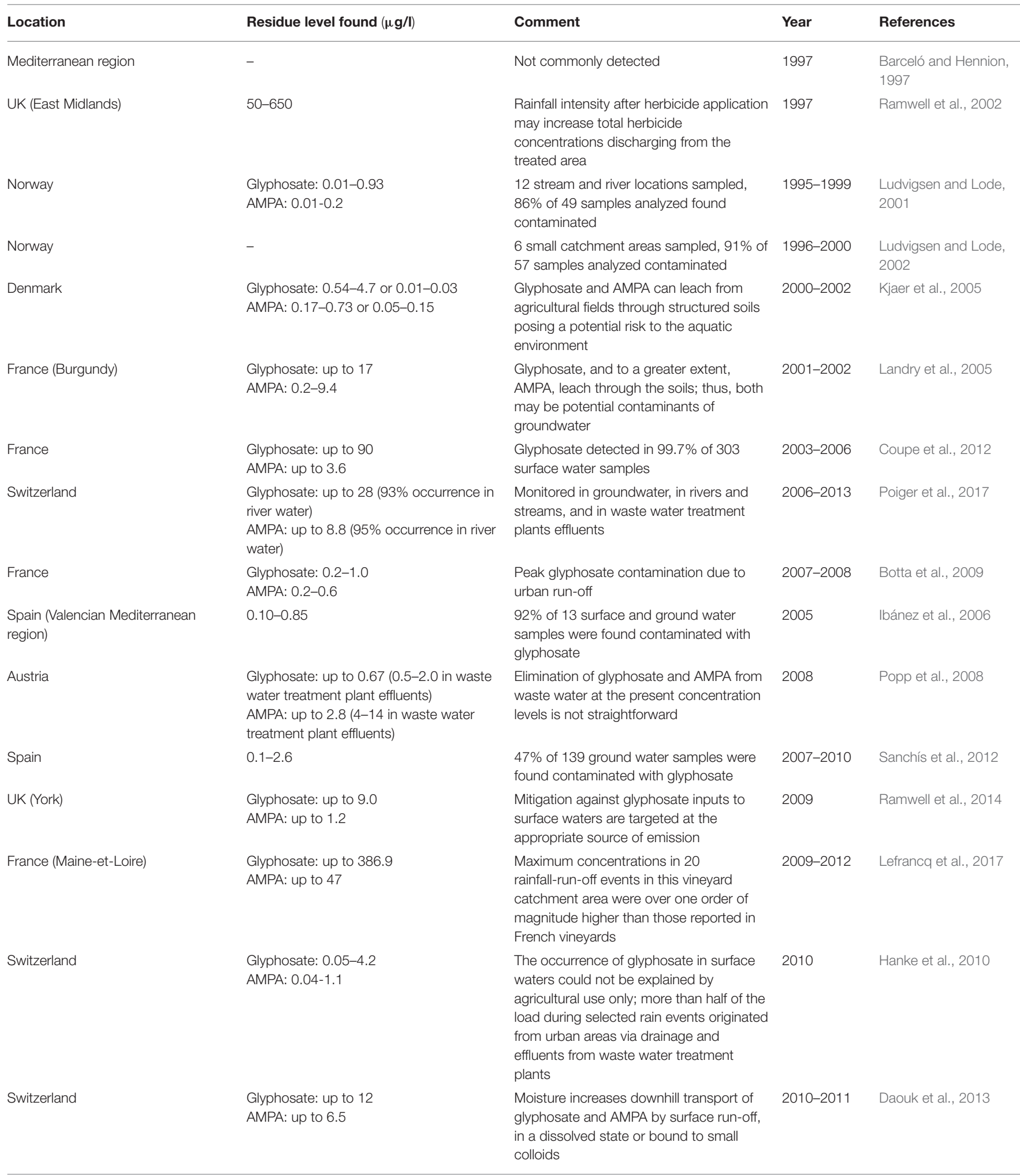


TABLE 3 | Continued

\begin{tabular}{|c|c|c|c|c|}
\hline Location & Residue level found ( $\mu \mathrm{g} / \mathrm{I})$ & Comment & Year & References \\
\hline Hungary & $0.04-0.98$ & $\begin{array}{l}50 \% \text { of } 42 \text { surface water samples were found } \\
\text { contaminated with glyphosate at significant } \\
\text { concentrations after a rainy period }\end{array}$ & 2010-2011 & Mörtl et al., 2013 \\
\hline Hungary & $0.13-0.46$ & $\begin{array}{l}\text { Varying leaching or run-off of glyphosate to } \\
\text { surface water }\end{array}$ & 2012 & Székács et al., 2015 \\
\hline $\begin{array}{l}\text { France (Auvergne- } \\
\text { Rhône-Alpes, } \\
\text { Provence-Alpes-Côte } \\
\text { d'Azur)) }\end{array}$ & Glyphosate: 0.05-0.81 AMPA: 0-05-0.09 & $\begin{array}{l}\text { Quantified in the low } \mu \mathrm{g} / \mathrm{l} \text { range in Rhône River } \\
\text { and its tributaries }\end{array}$ & 2013 & Slomberg et al., 2017 \\
\hline Switzerland & $\begin{array}{l}\text { Glyphosate: } 0.15 \text { (up to } 1.43 \text { in tributaries, } \\
0.018-0.35 \text { in waste water treatment plant } \\
\text { effluents) } \\
\text { AMPA: } 0.13 \text { ( } 0.024-0.42 \text { in tributaries, up to } \\
1.7 \text { in waste water treatment plant effluents) }\end{array}$ & $\begin{array}{l}\text { Seasonal occurrence in Lake Greifensee in July } \\
\text { (below concentrations in the two main } \\
\text { tributaries) and rapid dissipation of glyphosate, } \\
\text { but not AMPA }\end{array}$ & 2013 & Huntscha et al., 2018 \\
\hline Hungary & - & $\begin{array}{l}\text { Slowreed dissipation of glyphosate in } \\
\text { formulation and in the presence of algal biofilms }\end{array}$ & 2017 & Zhong et al., 2018 \\
\hline Italy (Lombardy Region) & up to 96 & $\begin{array}{l}\text { Sampling intensity increased due to more } \\
\text { concern about glyphosate residues during } \\
\text { 2012-2014 than previously, 2008-2011 }\end{array}$ & 2008-2014 & $\begin{array}{l}\text { Di Guardo and Finizio, } \\
2018\end{array}$ \\
\hline
\end{tabular}

analysis methods of better sensitivity and accuracy (Huhn, 2018). Glyphosate and AMPA were found to emerge in surface water by leaching from agricultural areas in the US and Canada (Edwards et al., 1980; Feng et al., 1990; Payne et al., 1990; Payne, 1992; Battaglin et al., 2005, 2009; Kolpin et al., 2006; Struger et al., 2008; Shipitalo and Owens, 2011; Coupe et al., 2012; Glozier et al., 2012) among others by the US Geological Survey (Kolpin et al., 2006), at concentrations up to 5,200 and $400 \mathrm{ng} / \mathrm{l}$, respectively in the US North Appalache and the Midwest (Battaglin et al., 2005, 2009) in regions, where the use of glyphosate-based pesticide formulations is substantial e.g., due to the cultivation of GT (RR) crops (Cuhra, 2015). Glyphosate has also been indicated as a significant water pollutant from intensive agriculture in Mexico (Ruiz-Toledo et al., 2014). The concentrations of glyphosate in surface waters in the EU appears to be lower, but consistently occurring e.g., Germany (Skark et al., 1998), the Mediterranean (Barceló and Hennion, 1997), the Northern region (Ludvigsen and Lode, 2001, 2002; Kjaer et al., 2005), in France (Botta et al., 2009; Van Stempvoort et al., 2016; Clausing et al., 2018) and elsewhere, and its dissipation has been found to be slowed down in formulation and in the presence of algal biofilms (Klátyik et al., 2017b). Thus, glyphosate residues have been deemed to be worldwide the most common pesticide contaminant in freshwater ecosystems, AMPA being the most frequent, glyphosate being the third most frequent contaminant in France (Villeneuve et al., 2011). The geographical distribution of peak glyphosate residue concentrations in surface and drinking water, reported worldwide, are depicted in Figure 4. As reference values, maximal permitted concentrations of glyphosate residues in drinking water in given regions are also indicated, revealing that maximum allowed pesticide residue levels in drinking water are 7,000-fold higher in the US than in the EU, and Australia is even more permissive (Note, that concentrations depicted worldwide, being peak values, do not reflect real life, everyday situations, rather correspond to worst cases).

It has been concluded that glyphosate and AMPA often occur as run-off from fields originating from glyphosate-based herbicide application. These residues not only became ubiquitous or "pseudo-persistent" contaminants in surface water, in periods with increasing concentrations over the years (McKnight et al., 2015; Carvalho, 2017; Primost et al., 2017), but through surface waters they were shown to be able to reach the seas as well, as documented in Germany in the estuaries of the Baltic Sea (Skeff et al., 2015). Glyphosate and AMPA were also found at up to 2.5 and $0.48 \mu \mathrm{g} / \mathrm{l}$ in rain and up to 9.1 and 0.97 $\mathrm{ng} / \mathrm{m}^{3}$ in air, respectively in the USA in Mississippi, Iowa and Indiana States in 2004 and 2007-2008 (Chang et al., 2011), where both have been identified in the same period as common surface water contaminants near agricultural fields (Majewski et al., 2014). Glyphosate and AMPA were detected both in rain and air near agricultural fields in the estuarine region of the Mississippi River in 2007, while such residues were not detected (possibly due to less sensitive analytical methods available at the time) in 1995 (Maqueda et al., 2017).

Glyphosate residue contamination has been demonstrated to correlate with sources of agricultural applications (Payne, 1992; Coupe et al., 2012) corresponding to GM crop cultivation (Barceló and Hennion, 1997; Skark et al., 1998; Australian Academy of Technological Sciences, and Engineering, 2002; Ramwell et al., 2002; Peruzzo et al., 2008; Aparicio et al., 2013; Davis et al., 2013; Mardiana-Jansar and Ismail, 2014; Lupi et al., 2015; Ronco et al., 2016; Caprile et al., 2017; Pérez et al., 2017), post-harvest chemical desiccation (Shipitalo and Owens, 2011; Soracco et al., 2018) or other technologies in intensive agriculture e.g., biomass production of industrial crops (Mardiana-Jansar and Ismail, 2014). Moreover, non-agricultural or urban uses of 


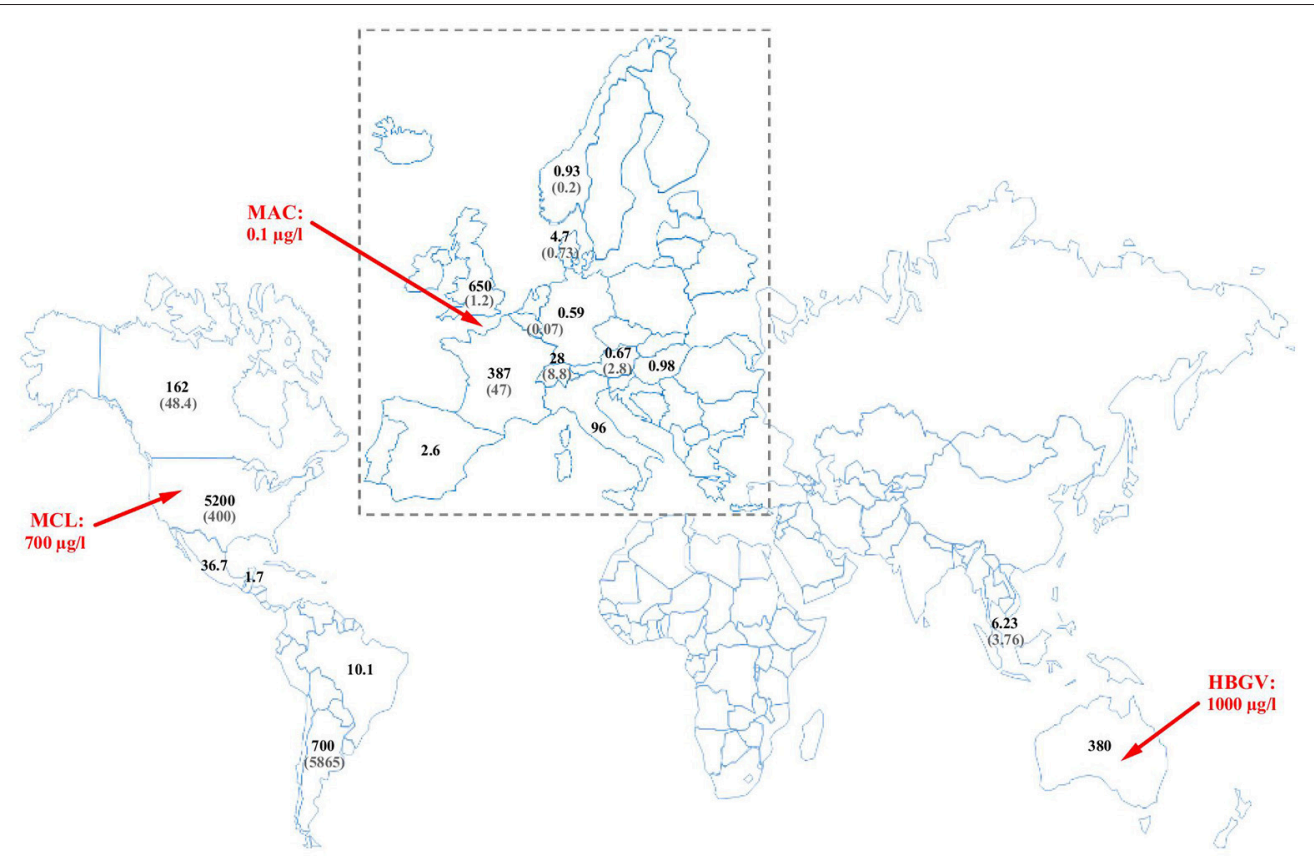

FIGURE 4 | Maximal residue levels ( $\mu \mathrm{g} /$ l) of glyphosate (black) and AMPA (gray in parentheses) in surface and ground water reported worldwide. Corresponding permitted levels in drinking water are indicated in red e.g., maximum admissible concentration (MAC) in the European Union, maximum contaminant level (MCL) in the US and health-based guideline value (HBGV) in Australia.

glyphosate have also been indicated (Kolpin et al., 2006; Botta et al., 2009; Hanke et al., 2010; Glozier et al., 2012) to contribute to environmental contamination. Soil contamination appears to show a closer correlation with agricultural usage intensity, while water contamination results from run-off events by precipitation (Landry et al., 2005; Maqueda et al., 2017; Poiger et al., 2017). Thus, glyphosate and AMPA were detected at concentrations 4-17 and 4-9 times greater than the sources of emission, respectively from agricultural soil and emitted respirable dust, 12 months after glyphosate application, in a central semiarid region of Argentina, indicating that these compounds are accumulated in the respirable dust and can potentially be a source of air contamination (Mendez et al., 2017). Moreover, glyphosate residues have often been detected in soil and sediments (Peruzzo et al., 2008; Aparicio et al., 2013; Battaglin et al., 2014; MardianaJansar and Ismail, 2014), and it has been shown by numerous studies that glyphosate reaches surface waters via dispersed small soil particles or colloids (Struger et al., 2008; Slomberg et al., 2017). A recent study provides a Europe-wide assessment of the dispersal of glyphosate and AMPA in EU agricultural topsoils, being present in $45 \%$ of the topsoils collected, originating from 11 countries and six crop systems, with a maximum concentration of $2 \mathrm{mg} / \mathrm{kg}$, as well as their potential spreading by wind and water erosion (Silva et al., 2018), further affected by small-scale sediment transport in water erosion (Bento et al., 2018), persisting under low bacterial activity in limited aerobic conditions or non-neutral $\mathrm{pH}$ (la Cecilia and Maggi, 2018), and adversely affecting soil microbial and nematodal diversity (Dennis et al., 2018). From the soil glyphosate can be translocated by plant roots; and it can affect non-target plants near agricultural ditches (Saunders and Pezeshki, 2015), and affect soil rhizosphere-associated bacterial communities (Newman et al., 2016) and soil Pseudomonas species (Aristilde et al., 2017). Toxicity of Roundup ${ }^{\circledR}$ to the soil filamentous fungus Aspergillus nidulans was reported with a median lethal dose $\left(\mathrm{LD}_{50}\right)$ corresponding to glyphosate concentrations of $90-112 \mathrm{mg} / \mathrm{l}, \sim 100$-fold below agricultural application levels (Nicolas et al., 2016). A proteomic analysis indicated protein expression modulation and possible metabolic disturbances (Poirier et al., 2017). Similar effects were not observed for Aspergillus section Flavi strains and A. niger (Carranza et al., 2017). Negative effects of glyphosate and/or N fertilization on soil enzymes and arbuscular mycorrhizal fungi were reported (Nivelle et al., 2018). A recent concern is that glyphosate (along with other herbicide active ingredients dicamba and 2,4-D), as well as common surfactants (Tween80, carboxymethyl cellulose) at or below recommended application concentrations can change the susceptibility of bacteria to a diverse range of antibiotics (ampicillin, chloramphenicol, ciprofloxacin, kanamycin, tetracycline) upon concurrent exposure, and thus, glyphosate may serve as one of the drivers for antibiotic resistance (Kurenbach et al., 2017; Van Bruggen et al., 2018). As indicated, through water pollution its formulations can disturb aquatic ecosystems (Vera et al., 2010; Perez et al., 2011) including fish (Jofré et al., 2013). Removal or degradation of glyphosate residues from raw drinking water by bank filtration may not be efficient, but oxidants used in water treatment (e.g., $\mathrm{Cl}_{2}$ or $\mathrm{O}_{3}$ ) were shown to be effective in degrading their 
concentration below the EU drinking water threshold level of $0.1 \mu \mathrm{g} / \mathrm{l}$ (Jönsson et al., 2013). Nonetheless, glyphosate residues were reported in bottled drinking water (Rendón-von Osten and Dzul-Caamal, 2017). Glyphosate residues were detected in honey and soy sauce (Rubio et al., 2014), in produce (Bøhn et al., 2014), processed food products, even in human specimens (blood, urine, mother's milk) (Knudsen et al., 2017; Rendón-von Osten and Dzul-Caamal, 2017). It should be noted, however, that measurements of glyphosate in complex biological matrices e.g., blood and breast milk, that led to positive scores used ELISA methods of questionable accuracy, and instrumental analysis by LC-MS/MS did not find glyphosate above its limit of detection in human breast milk (McGuire et al., 2016; Steinborn et al., 2016). As a result of its expanding release into the environment, increased residue levels have been detected in crops, 0.3-5.2 $\mathrm{mg} / \mathrm{kg}$ glyphosate, $0.3-5.7 \mathrm{mg} / \mathrm{kg}$ AMPA (Arregui et al., 2004).

In the US, the accepted MRL for glyphosate residues in drinking water is $700 \mu \mathrm{g} / \mathrm{l}$ (United States Environmental Protection Agency, 2003), while $0.1 \mu \mathrm{g} / \mathrm{l}$ in the EU under the Drinking Water Directive (European Parliament Council, 1998). The MRL of glyphosate (among all pesticide residues) in the aquatic environment used to be $1.0 \mu \mathrm{g} / \mathrm{l}$ in the EU (European Parliament Council, 1976). Currently, there are no MRLs defined for surface water according to the Water Framework Directive (European Commission, 2000), as glyphosate or AMPA are not listed among priority substances for which environmental quality standards have been set. However, both compounds are likely to be re-considered as priority substances (European Parliament Council, 2006; European Parliament, 2008).

Most recent results in residue analysis in food in the EU indicated a more favorable picture. Analyzed in 22 countries in EU MSs (predominantly in Germany) in raw and processed food products (mainly fruits, nuts, vegetables and cereals, yet in limited numbers in oilseeds and soybeans, and none reported in animal products) in 2014, detectable levels of glyphosate residues were found in $4 \%$ of the samples, but at levels all below the MRL with the exception of a dry bean sample, where the residue level, $2.3 \mathrm{mg} / \mathrm{kg}$ was $15 \%$ above the MRL. The highest incidence of glyphosate residue levels was detected in sunflower seeds, dry lentils and peas, mustard and linseeds, soybeans, as well as barley, wheat, oats and rye among cereals (European Food Safety Authority, 2017b). Characterizing and quantifying glyphosate residues in food and feed of plant and animal origin, considering their stability in those matrices, estimating dietary exposure of consumers and comparing it to EFSA reference toxicity values for glyphosate and AMPA published in 2015 (European Food Safety Authority, 2015a) and for N-acetyl-glyphosate and N-acetylAMPA published in 2018 (European Food Safety Authority, 2018a), without their any further assessment, EFSA proposed 207 new MRLs with proposed ERD (glyphosate plus AMPA and $\mathrm{N}$-acetyl-glyphosate) to replace the existing ERD (glyphosate) (European Food Safety Authority, 2018b), and considered them to pose no apparent risk to consumers (European Food Safety Authority, 2018a,b). These proposed MRLs are in 153 cases more restricting (lower than before) than the existing ones, being set at an improved LOD $(0.05 \mathrm{mg} / \mathrm{kg})$ made possible by advanced analytical methods, but are more permissive (higher than before) for main commodity crops e.g., potatoes, dried commodities (beans, lentils, peas, lupine beans and linseeds), olives for oil production, grains (barley, buckwheat and other pseudo-cereals, millet, oat, rye, sorghum, wheat), seeds (borage, rape/canola, cotton, maize), soybeans and sugarcanes, as well as food of animal origin (swine, bovine, sheep, bovine, equine and poultry muscle and tissues, milk and bird eggs). The stricter MRLs represent 2- to 10 -fold (in the case of wild fungi 1,000-fold) lower values, than the existing ones, while proposed alleviations correspond to 1.5- to 300-fold increase in other MRLs. However, while lowered MRLs apply mostly to non-problematic commodities, higher values are proposed for commodities, where common glyphosate contamination has been reported, or where high glyphosate metabolite levels are endogenous (GT crops with transgenic GOX or GAT enzymes). Such mitigation in the requirements is consonant with the increase proposed also in the ADI value for glyphosate, on the one hand, yet appears to reflect as if regulatory rigor yielded to technology, as limits previously considered necessary and accepted by industry are proposed to be replaced with more permissive ones, on the other hand. As for compliance of MRL, it is worth mentioning that negative health outcomes have been observed in laboratory animal studies showing toxicity at levels of exposure below regulatory set safety limits (Mesnage et al., 2015b, 2017b; Defarge et al., 2016).

Although the number of results available in the scientific literature on glyphosate residue levels in human tissues is limited, human biomonitoring is of prominent importance as its results serve as primary end-point indicators of exposure. Biomonitoring of glyphosate residues in human urine have been carried out in the USA (Acquavella et al., 2003; Curwin et al., 2007; Mills et al., 2017), Europe (Mesnage et al., 2012; Krüger et al., 2014; Connolly et al., 2017; Conrad et al., 2017) and Sri Lanka (Jayasumana et al., 2015), and indicated maximal concentrations of $0.45-233 \mathrm{ng} / \mathrm{ml}$. Within these studies, one report compared glyphosate levels in the urine of humans and livestock, and found over one order of magnitude higher levels in the latter (Krüger et al., 2014). A survey of the human biomonitoring studies argued that the results posed no health concerns as corresponding exposures were estimated to be magnitudes below the ADI or Acceptable Operator Exposure Level values, but conceded characteristic differences between exposure levels in Europe and North America with substantially higher maximum levels in the latter region (Niemann et al., 2015), levels being $0.65-5 \mathrm{ng} / \mathrm{ml}$ in Europe and $18-233$ in the US. A systematic study carried out in Southern California found that the mean glyphosate and AMPA levels in human urine increased between 1993 and 2016, and reached 0.449 and $0.401 \mathrm{ng} / \mathrm{ml}$, respectively (Mills et al., 2017). It has to be noted that levels of $3.3-73.5 \mathrm{ng} / \mathrm{ml}$ have been reported in a non-peer reviewed report in Germany (Connolly et al., 2017).

A wide range of ecotoxicological and human health problems related to glyphosate and its formulated PPPs have been indicated (Székács and Darvas, 2012; Mensah et al., 2015; Kurenbach et al., 2017), partially related to the chelating properties of glyphosate (Mertens et al., 2018). Moreover, ecotoxicological and resistance-related consequences of the extended use of glyphosate (Schütte et al., 2017) or of the use of GT GM 
crops (Pandolfo et al., 2018) have been emphasized, along with effects non-target terrestrial plants as well (Cederlund, 2017). As for emerging plant resistance against glyphosate, glyphosate itself and glyphosate-based herbicides have been shown to affect the disease resistance and health of plants by undermining their innate physiological defenses in mechanisms related to the mode of action of glyphosate, even in crops engineered for glyphosate-tolerance, and by interferences with the local microbial ecology in the rhizosphere (Martinez et al., 2018). The evolution of resistance was shown to occur due to gene amplification (Chen et al., 2017; Dolatabadian et al., 2017; Fernandez-Escalada et al., 2017; Han et al., 2017; Jugulam and Gill, 2018). Epigenetic alterations through increased levels of DNA and histone methylation were identified in response to exposure to glyphosate (Nardemir et al., 2015; Kim et al., 2017; Margaritopoulou et al., 2018; Markus et al., 2018). The results suggest that epigenetic pathways may influence the regulation of genes important for herbicide detoxification (Markus et al., 2018). As for ecotoxicity, more research on the effects of exposure, particularly at sub-lethal levels, using appropriate target biomonitor species (Kissane and Shephard, 2017) and a corresponding new concept in agriculture are urged (Nicolopoulou-Stamati et al., 2016; Torretta et al., 2018). Taking these indications into consideration, and also considering the wide occurrence of glyphosate residues in environmental matrices, foodstuff and biological matrices, including the urine of livestock and humans, our current estimations of dietary exposure (Stephenson et al., 2018) may need to be reconsidered, which could substantially modify risk assessment. It has to be noted that the ecotoxicological profile of replacement herbicide active ingredients proposed as alternatives to glyphosate appear to be similar or worse than that of glyphosate itself, both in the area of conventional treatment and desiccant technology (e.g., bromoxynil, diquat or other total herbicides) or on HT GM crops (e.g., 2,4-D, oxynil, dicamba, glufosinate). Nonetheless, this does not constitute a part of risk assessment of glyphosate, but is to be considered by risk managers in their decision-making. Moreover, practically any xenobiotic substance is prone to lead to adverse effects when used in such excessive quantities as glyphosate.

\section{CONCLUSION}

The issue of re-registration of glyphosate in the EU and corresponding evaluation reports clearly show a fundamental difference between risk- and hazard-based assessments of regulated products. Considering acute toxicity, legislatory decision-makers focus on risks as a product of hazard and exposure, and weigh the subsequently identified hazards based on their likelihood of occurrence through real exposures. In contrast to acute toxicity, however, EU pesticide regulation is hazard-based (and not risk-based) for carcinogenicity, reproductive/developmental toxicity, neurotoxicity and endocrine effects. The main problem, where the re-registration routine of pesticides may become seriously perplexed, is that at EU level, the authorities, following their legal mandate, focus on the toxicology of the active ingredient(s), while in real life situations subjects are exposed to the formulated, complex products, reflected in the IARC evaluation, as that agency is not legally bound to EU authorization policies. Moreover, government or government-related agencies have to consider all stakeholders, including patent holders and industry, in their assessment. An international expert agency in public health, however, may focus on hazards in its assessment, particularly if novel hazards have been identified in relation to the target substance, and also if concentration- or dose-dependence of the health effects are questionable or do not exist, as often seen for endocrine disruption effects (Vandenberg et al., 2012). A particular issue in the EU is that active ingredients used in PPPs are regulated at the EU level, while formulated pesticide products are governed at MS level. In other words, the responsibility of sound toxicological evaluation of the formulated products lies in the EU at MS level. Therefore, re-assessment of glyphosate can indeed focus on the parent compound itself, as possible biological and health effects of other formulants (e.g., surfactant and other additives) will be considered during the registration of the formulated products at MS level. The withdrawal of glyphosate-based herbicides containing formulating agent POEA and the ban of the use of glyphosate as a post-harvest chemical desiccant at MS level are effective means to reduce environmental contamination and to mitigate environmental and human health consequences. Nonetheless, the wide occurrence of glyphosate and its residues as a ubiquitous contaminant in environmental matrices, feed and food, and even in livestock and human samples indicates that our exposure to this substance, boosted in use by expansion of GM crops worldwide and the use of pre- or post-harvest chemical desiccation in agriculture, may be substantially higher than predicted from dietary exposure models, which may therefore cause our current position in risk assessment to be re-assessed.

Data on occupational or community exposure to glyphosate residues have been shown to be limited (International Agency for Research on Cancer, 2017), and thus, expected exposure levels need to be updated, based not only on earlier estimations on the total food basket, but also on recent environmental and biological monitoring data indicating increased levels or more wide-spread occurrence of glyphosate residues. Critical gaps in the re-registration of glyphosate, including the EU re-registration process itself, have been addressed (European Parliament Council, 2002; Myers et al., 2016), particularly those considered more pressing by recent scientific findings. These include: (a) increasing exposures of EU citizens to glyphosate residues, supported by human and environmental biomonitoring data in limited number (Curwin et al., 2007; Mesnage et al., 2012; Krüger et al., 2014; Niemann et al., 2015; Connolly et al., 2017; Conrad et al., 2017; Mills et al., 2017; Vandenberg et al., 2017), but identifying a clearly rising trend; (b) carcinogenicity classification by IARC, evidence of linkages of glyphosate or its formulated products to non-Hodgkin's lymphoma (Hardell et al., 2002; De Roos et al., 2003, 2005; Eriksson et al., 2008; Schinasi and Leon, 2014; Mesnage et al., 2015b), and effective dose levels indicated in rodent oncogenicity studies being 1-2 orders of magnitude lower when formulated glyphosate-based herbicides were used compared to those obtained with the pure 
active ingredient; (c) evidence of contributions to fatal chronic kidney disease by glyphosate in areas with heavy metals in water (Jayasumana et al., 2014, 2015) and the finding of nonalcoholic fatty liver disease upon exposure to a glyphosatebased herbicide (Roundup ${ }^{\circledR}$ ) (Mesnage et al., 2017b), coupled with the powerful animal metabolism data embedded within the re-registration document appendices (showing glyphosate and AMPA levels higher in kidney than in liver, and much higher than in muscle tissue); as well as (d) problems (e.g., risk assessment studies for regulatory purposes of re-registration of glyphosate being carried out with pure glyphosate) arising from the dual character of pesticide registration in the EU with active ingredients authorized at EU and formulated products at MS level (Klátyik et al., 2017a). In light of these findings, earlier risk assessment statements (Williams et al., 2000) are untenable for both hazard and exposure levels.

In summary, the "glyphosate debate" among agencies is mostly confined to carcinogenicity, while a variety of other effects (e.g., non-alcoholic fatty liver disease, endocrine disruption) have also been found. The in vitro sensitivity assays on a variety of cell lines indicate that glyphosate is less toxic than its common co-formulants e.g., POEA. Moreover, synergistic effects between glyphosate and its co-formulants cannot be ruled

\section{REFERENCES}

Abarikwu, S. O., Akiri, O. F., Durojaiye, M. A., and Adenike, A. (2015). Combined effects of repeated administration of Bretmont Wipeout (glyphosate) and Ultrazin (atrazine) on testosterone, oxidative stress and sperm quality of Wistar rats. Toxicol. Mech. Methods 25, 70-80. doi: 10.3109/15376516.2014.989349

Acquavella, J., Doe, J., Tomenson, J., Chester, G., Cowell, J., and Bloemen, L. (2003). Epidemiologic studies of occupational pesticide exposure and cancer: regulatory risk assessments and biologic plausibility. Ann. Epidemiol. 13, 1-7. doi: 10.1016/S1047-2797(02)00423-4

Acquavella, J., Farmer, D., and Cullen, M. R. (1999). A case-control study of non-Hodgkin lymphoma and exposure to pesticides. Cancer 86, 729-730.

Acquavella, J., Garabrant, D., Marsh, G., Sorahan, T., and Weed, D. L. (2016). Glyphosate epidemiology expert panel review: a weight of evidence systematic review of the relationship between glyphosate exposure and non-Hodgkin's lymphoma or multiple myeloma. Crit. Rev. Toxicol. 46(Suppl. 1), 28-43. doi: $10.1080 / 10408444.2016 .1214681$

AgroNews Scientists challenge EFSA claim of glyphosate safety (2015). AgroNews Scientists Challenge EFSA claim of Glyphosate Safety 18/12/2015. Available online at: http://news.agropages.com/News/print-\$-\$16646---.htm

Alvarez-Moya, C., Silva, M. R., Ramírez, C. V., Gallardo, D. G., Sánchez, R. L., Aguirre, A. C., et al. (2014). Comparison of the in vivo and in vitro genotoxicity of glyphosate isopropylamine salt in three different organisms. Genet. Mol. Biol. 37, 105-110. Available online at: http://www.scielo.br/pdf/gmb/v37n1/ a16v37n1.pdf

Amerio, P., Motta, A., Toto, P., Pour, S. M., Pajand, R., Feliciani, C., et al. (2004). Skin toxicity from glyphosate-surfactant formulation. J. Toxicol. Clin. Toxicol. 42, 317-319. doi: 10.1081/CLT-120038769

Andreotti, G., Koutros, S., Hofmann, J. N., Sandler, D. P., Lubin, J. H., Lynch, C. F., et al. (2018). Glyphosate use and cancer incidence in the Agricultural Health Study. J. Natl. Cancer Inst. 110:djx233. doi: 10.1093/jnci/djx233

Anton, A., Fekete, G., Darvas, B., and Székács, A. (2014). "Environmental risk of chemical agriculture," in Engineering Tools for Environmental Risk Management. (Vol. 1) Environmental Deterioration and Contamination Problems and Their Management, eds K. Gruiz, T. Meggyes, and E. Fenyvesi (Boca Raton, FL: CRC Press), 93-112. out. POEA has been banned in glyphosate-based preparations in various MSs in hope to solve the "glyphosate case." Nevertheless, inhibition of aromatases has been demonstrated at very low concentrations, implying hormonal disrupting effects, and the estrogenic potential of glyphosate (and its formulated products) have been indicated by their estrogen receptor activation.

\section{AUTHOR CONTRIBUTIONS}

AS conceived the concept of the review. AS and BD wrote the manuscript together, edited the manuscript, and took responsibility for the integrity of the data.

\section{FUNDING}

This research was supported by projects Mechanism-related teratogenic, hormone modulant and other toxicological effects of veterinary and agricultural surfactants (OTKA K109865) and In situ, complex water quality monitoring by using direct or immunofluorimetry and plasma spectroscopy (NVKP_161-2016-0049) by the National Scientific Research Fund of Hungary and the Hungarian National Research, Development and Innovation Office, respectively.

Antoniou, M., Habib, M. E. E.-D. M., Howard, C. V., Jennings, R. C., Leifert, C., Nodari, R. O., et al. (2011). Roundup and birth defects. Is the public being kept in the dark? Lancashire, UK: Earth Open Source. Available online at: http://earthopensource.org/earth-open-source-reports/ roundup-and-birth-defects-is-the-public-being-kept-in-the-dark

Antoniou, M., Habib, M. E. M., Howard, C. V., Jennings, R. C., Leifert, C., Nodari, R. O., et al. (2012). Teratogenic effects of glyphosate-based herbicides: Divergence of regulatory decisions from scientific evidence. Environ. J. Anal. Toxicol. S4:006. doi: 10.4172/2161-0525.S4-006

Antunes, A. M., Rocha, T. L., Pires, F. S., de Freitas, M. A., Leite, V. R. M. C., Arana, S., et al. (2017). Gender-specific histopathological response in guppies Poecilia reticulata exposed to glyphosate or its metabolite aminomethylphosphonic acid. J. Appl. Toxicol. 37, 1098-1107. doi: 10.1002/jat.3461

Aparicio, V. C., De Gerónimo, E., Marino, D., Primost, J., Carriquiriborde, P., and Costa, J. L. (2013). Environmental fate of glyphosate and aminomethylphosphonic acid in surface waters and soil of agricultural basins. Chemosphere 93, 1866-1873. doi: 10.1016/j.chemosphere.2013. 06.041

Argueta, J. A., and Torres, A. (2017). Assessment of developmental toxicity potential of glyphosate-based herbicides using Drosophila melanogaster primary embryonic stem cell cultures. Birth Defects Res. 109:680. doi: 10.5487/TR.2013.29.4.221

Aristilde, L., Reed, M. L., Wilkes, R. A., Youngster, T., Kukurugya, M. A., and Katz, V. (2017). Sasaki, C. R. S. Glyphosate-induced specific and widespread perturbations in the metabolome of soil Pseudomonas species. Front. Environ. Sci. 5:34. doi: 10.3389/fenvs.2017.00034

Armiliato, N., Ammar, D., Nezzi, L., Straliotto, M., Muller, Y. M., and Nazari, E. M. (2014). Changes in ultrastructure and expression of steroidogenic factor-1 in ovaries of zebrafish Danio rerio exposed to glyphosate. J. Toxicol. Environ. Health A 77, 405-414. doi: 10.1080/15287394.2014.8 80393

Arregui, M. C., Lenardón, A., Sanchez, D., Maitre, M. I., Scotta, R., and Enrique, S. (2004). Monitoring glyphosate residues in transgenic glyphosate-resistant soybean. Pest Manage. Sci. 60, 163-166. doi: 10.1002/ps.775

Australian Academy of Technological Sciences, and Engineering, (2002). Pesticide Use in Australia. Parkville: AATSE. 136, 161, 241. Available 
online at: https://www.atse.org.au/content/publications/reports/agriculture/ pesticide-use-in-australia.aspx

Avigliano, L., Canosa, I. S., Medesani, D. A., and Rodríguez, E. M. (2018). Effects of glyphosate on somatic and ovarian growth in the estuarine crab Neohelice granulata, during the pre-reproductive period. Water Air Soil Pollut. 229:44. doi: 10.1007/s11270-018-3698-0

Bach, N. C., Marino, D. J. G., Natale, G. S., and Somoza, G. M. (2018). Effects of glyphosate and its commercial formulation, Roundup ${ }^{\circledR}$ Ultramax, on liver histology of tadpoles of the neotropical frog, Leptodactylus latrans (amphibia: Anura). Chemosphere 202, 289-297. doi: 10.1016/j.chemosphere.2018.03.110

Baier, C. J., Gallegos, C. E., Raisman-Vozari, R., and Minetti, A. (2017). Behavioral impairments following repeated intranasal glyphosate-based herbicide administration in mice. Neurotoxicol. Teratol. 64, 63-72. doi: 10.1016/j.ntt.2017.10.004

Baier, F., Gruber, E., Hein, T., Bondar-Kunze, E., Ivanković, M., Mentler, A., et al. (2016a). Non-target effects of a glyphosate-based herbicide on Common toad larvae (Bufo bufo, Amphibia) and associated algae are altered by temperature. PeerJ 4:e2641. doi: 10.7717/peerj.2641

Baier, F., Jedinger, M., Gruber, E., and Zaller, J. G. (2016b). Temperaturedependence of glyphosate-based herbicide's effects on egg and tadpole growth of common toads. Front. Environ. Sci. 4:51. doi: 10.3389/fenvs.2016.00051

Baird, D. D., Upchurch, R. P., Homesley, W. B., and Franz, J. E. (1971). "Introduction of a new broadspectrum postemergence herbicide class with utility for herbaceous perennial weed control," in Proceedings of the 26th North Central Weed Conference, North Central Weed Science Society (Kansas City, MO; Omaha, NE) 64-68.

Barbosa, M. C., Aiassa, D., and Mañas, F. (2017). Evaluación de daño al adn en leucocitos de sangre periférica humana expuestos al herbicida glifosato. Rev. Int. Contam. Ambie 33, 403-410. doi: 10.20937/RICA.2017.33.03.04

Barceló, D., and Hennion, M.-C. (1997). Trace Determination of Pesticides and Their Degradation Products in Water. Amsterdam: Elsevier. Available online at: http://store.elsevier.com/Trace-Determination-of-Pesticides-and-theirDegradation-Products-in-Water-BOOK-REPRINT/Damia-Barcelo/isbn9780444818423

Battaglin, W. A., Kolpin, D. W., Scribner, E. A., Kuivila, K. M., and Sandtrom, M. W. (2005). Glyphosate, other herbicides, and transformation products in Midwestern streams, 2002. J. Am. Water Res. Assoc. 41, 323-332. doi: 10.1111/j.1752-1688.2005.tb03738.x

Battaglin, W. A., Meyer, M. T., Kuivila, K. M., and Dietze, J. E. (2014). Glyphosate and its degradation product AMPA occur frequently and widely in U.S. soils, surface water, groundwater, and precipitation. J. Am. Water Res. Assoc. 50, 275-290. doi: 10.1111/jawr.12159

Battaglin, W., Rice, K. C., Focazio, M. J., Salmons, S., and Barry, R. X. (2009). To occurrence of glyphosate, atrazine, and other pesticides in vernal pools and adjacent streams in Washington, D. C., Maryland, Iowa, and Wyoming, 2005-2006. Environ. Monit. Assess. 155, 281-307. doi: 10.1007/s10661-008-0435-y

BAuA Federal Institute for Occupational Safety and Health (2016). CLH Report. Proposal for Harmonized Classification and Labelling. Substance name: Nphosphonomethyl)glycine; Glyphosate (ISO). BAuA. Available online at: https:// www.echa.europa.eu/documents/10162/13626/clh_report_glyphosate_en.pdf

BCC Research (2012). Global Market for Pesticides to Reach $\$ 65.3$ Billion in 2017. Wellesley: BCC Research LLC. Available online at: https:// www.bccresearch.com/pressroom/chm/global-market-pesticides-reach|protect \T1\textdollar65.3-billion-2017

Bellantuono, V., Cassano, G., and Lippe, C. (2014). Pesticides alter ion transport across frog (Pelophylax kl. esculentus) skin. Chem. Ecol. 30, 602-610. doi: 10.1080/02757540.2014.917177

Benachour, N., and Séralini, G.-E. (2009). Glyphosate formulations induce apoptosis and necrosis in human umbilical, embryonic, and placental cells. Chem. Res. Toxicol. 22, 97-105. doi: 10.1021/tx800218n

Benachour, N., Sipahutar, H., Moslemi, S., Casnier, C., Travert, C., and Séralini, G.-E. (2007). Time- and dose-dependent effects of Roundup on human embryonic and placental cells. Arch. Environ. Contam. Toxicol. 53, 126-133. doi: 10.1007/s00244-006-0154-8

Benbrook, C. M. (2016). Trends in glyphosate herbicide use in the United States and globally. Environ. Sci. Eur. 28:3. doi: 10.1186/s12302-016-0 070-0
Benedetti, A. L., Vituri Cde, L., Trentin, A. G., Domingues, M. A., and Alvarez-Silva, M. (2004). The effects of sub-chronic exposure of Wistar rats to the herbicide Glyphosate-Biocarb. Toxicol. Lett. 153, 227-232. doi: 10.1016/j.toxlet.2004.04.008

Benford, D., Halldorsson, T., Jeger, M. J., Knutsen, H. K., More, S., Naegeli, H., et al. (2018). Guidance on uncertainty analysis in scientific assessments. EFSA J. 16, 5123. doi: 10.2903/j.efsa.2018.5123

Bento, C. P. M., Commelin, M. C., Baartman, J. E. M., Yang, X., Peters, P., Mol, H. G. J., et al. (2018). Spatial glyphosate and AMPA redistribution on the soil surface driven by sediment transport processes - A flume experiment. Environ. Pollut. 234, 1011-1020. doi: 10.1016/j.envpol.2017. 12.003

Berger, G., Graef, F., Pallut, B., Hoffmann, J., Brühl, C. A., and Wagner, N. (2018). How does changing pesticide usage over time affect migrating amphibians: a case study on the use of glyphosate-based herbicides in German agriculture over 20 years. Front. Environ. Sci. 6:6. doi: 10.3389/fenvs.2018.00006

Böcker, T., Britz, W., and Finger, R. (2018). Modelling the effects of a glyphosate ban on weed management in silage maize production. Ecol. Econ. 145, 182-193. doi: 10.1016/j.ecolecon.2017.08.027

Bøhn, T., Cuhra, M., Traavik, T., Sanden, M., Fagan, J., and Primicerio, R. (2014). Compositional differences in soybeans on the market: glyphosate accumulates in Roundup Ready GM soybeans. Food Chem. 153, 207-215. doi: 10.1016/j.foodchem.2013.12.054

Bókony, V., Mikó, Z., Móricz, Á. M., Krüzselyi, D., and Hettyey, A. (2017). Chronic exposure to a glyphosate-based herbicide makes toad larvae more toxic. Proc. $R$ Soc. B 284:20170493. doi: 10.1098/rspb.2017.0493

Bolognesi, C., Bonatti, S., Degan, P., Gallerani, E., Peluso, M., Rabboni, R., et al. (1997). Genotoxic activity of glyphosate and its technical formulation Roundup. J. Agric. Food Chem. 45, 1957-1962. doi: 10.1021/jf9606518

Bonfanti, P., Saibene, M., Bacchetta, R., Mantecca, P., and Colombo, A. (2018). A glyphosate micro-emulsion formulation displays teratogenicity in Xenopus laevis. Aquat. Toxicol. 195, 103-113. doi: 10.1016/j.aquatox.2017.12.007

Bonny, S. (2011). Herbicide-tolerant transgenic soybean over 15 years of cultivation: pesticide use, weed resistance, and some economic issues. Case of the USA. Sustainability 3, 1302-1322. doi: 10.3390/su3091302

Botta, F., Lavison, G., Couturier, G., Alliot, F., Moreau-Guigon, E., Fauchon, N., et al. (2009). Transfer of glyphosate and its degradatle AMPA to surface waters through urban sewerage systems. Chemosphere 77, 133-139. doi: 10.1016/j.chemosphere.2009.05.008

Braz-Mota, S., Sadauskas-Henrique, H., Duarte, R. M., Val, A. L., and Almeida-Val, V. M. (2015). Roundup ${ }^{\circledR}$ exposure promotes gills and liver impairments, DNA damage and inhibition of brain cholinergic activity in the Amazon teleost fish Colossoma macropomum. Chemosphere 135, 53-60. doi: 10.1016/j.chemosphere.2015.03.042

Bridi, D., Altenhofen, S., Gonzalez, J. B., Reolon, G. K., and Bonan, C. D. (2017). Glyphosate and Roundup ${ }^{\circledR}$ alter morphology and behavior in zebrafish. Toxicology 392, 32-39. doi: 10.1016/j.tox.2017.10.007

Brusick, D., Aardema, M., Kier, L., Kirkland, D., and Williams, G. (2016). Genotoxicity Expert Panel review: weight of evidence evaluation of the genotoxicity of glyphosate, glyphosate-based formulations, and aminomethylphosphonic acid. Crit. Rev. Toxicol. 46, 56-74. doi: 10.1080/10408444.2016.1214680

Burtscher-Schaden, H., Clausing, P., and Robinson, C. (2017). Glyphosate and Cancer: Buying Science. How Industry Strategized (and regulators Colluded) in an Attempt to Save the World's Most Widely Used Herbicide From a Ban. Hamburg: Pesticide Action Network Germany. Available online at: https://www.global2000.at/sites/global/files/Glyphosate_and_cancer_Buying_ science_EN_0.pdf

Cai, W., Ji, Y., Song, X., Guo, H., Han, L., Zhang, F., et al. (2017). Effects of glyphosate exposure on sperm concentration in rodents: a systematic review and meta-analysis. Environ. Toxicol. Pharmacol. 55, 148-155. doi: 10.1016/j.etap.2017.07.015

Canosa, I. S., Silveyra, G. R., Avigliano, L., Medesani, D. A., and Rodríguez, E. M. (2018). Ovarian growth impairment after chronic exposure to Roundup Ultramax ${ }^{\circledR}$ in the estuarine crab Neohelice granulata. Environ. Sci. Pollut. Res. 25, 1568-1575. doi: 10.1007/s11356-017-0581-2

Caprile, A. C., Aparicio, V., Sasal, C., and Andriulo, E. (2017). Variation in glyphosate and AMPA concentrations of surface water and groundwater. 
Geophys. Res. Abs. 19:EGU2017-2068. Available online at: http:// meetingorganizer.copernicus.org/EGU2017/EGU2017-2068.pdf

Carranza, C. S., Barberis, C. L., Chiacchiera, S. M., and Magnoli, C. E. (2017). Assessment of growth of Aspergillus spp. from agricultural soils in the presence of glyphosate. Rev. Argent Microbiol. 49, 384-393. doi: 10.1016/j.ram.2016.11.007

Carrasco, A. (2013). "Teratogenesis by glyphosate based herbicides and other pesticides. Relationship with the retinoic acid pathway," in GM-Crop Cultivation - Ecological Effects on a Landscape Theorie in der Ökologie. (Vol. 17), eds B. Scale Breckling, R. Verhoeven (Germany: Peter Lang), 113-117.

Carvalho, F. P. (2017). Pesticides, environment, and food safety. Food Energ. Sec. 60, 48-60. doi: 10.1002/fes3.108

Cassault-Meyer, E., Gress, S., Séralini, G. É., and Galeraud-Denis, I. (2014). An acute exposure to glyphosate-based herbicide alters aromatase levels in testis and sperm nuclear quality. Environ. Toxicol. Pharmacol. 38, 131-140. doi: 10.1016/j.etap.2014.05.007

Castro Berman, M., Marino, D. J. G., Quiroga, M. V., and Zagarese, H. (2018). Occurrence and levels of glyphosate and AMPA in shallow lakes from the Pampean and Patagonian regions of Argentina. Chemosphere 200, 513-522. doi: 10.1016/j.chemosphere.2018.02.103

Castro, M. J. L., Ojeda, C., and Cirelli, A. F. (2014). Advances in surfactants for agrochemicals. Environ. Chem. Lett. 12, 85-95. doi: 10.1007/s10311-013-0432-4

Cattani, D., de Liz Oliveira Cavalli, V. L., Heinz Rieg, C. E., Domingues, J. T., Dal-Cim, T., Tasca, C. I., et al. (2014). Mechanisms underlying the neurotoxicity induced by glyphosate-based herbicide in immature rat hippocampus: involvement of glutamate excitotoxicity. Toxicology 320, 34-45. doi: 10.1016/j.tox.2014.03.001

Cavalcante, D. G. S. M., Martinez, C. B. R., and Sofia, S. H. (2008). Genotoxic effects of Roundup on the fish Prochilodus lineatus. Mutat. Res. 655, 41-46. doi: 10.1016/j.mrgentox.2008.06.010

Çavas, T., and Könen, S. (2007). Detection of cytogenetic and DNA damage in peripheral erythrocytes of goldfish (Carassius auratus) exposed to a glyphosate formulation using the micronucleus test and the comet assay. Mutagenesis 22, 263-268. doi: 10.1093/mutage/gem012

Cederlund, H. (2017). Effects of spray drift of glyphosate on nontarget terrestrial plants. A critical review. Environ. Toxicol. Chem. 36, 2879-2886. doi: 10.1002/etc.3925

Chang, E. T., and Delzell, E. (2016). Systematic review and meta-analysis of glyphosate exposure and risk of lymphohematopoietic cancers. J. Environ. Sci. Health B 51, 402-434. doi: 10.1080/03601234.2016.1142748

Chang, F. C., Simcik, M. F., and Capel, P. D. (2011). Occurrence and fate of the herbicide glyphosate and its degradate aminomethylphosphonic acid in the atmosphere. Environ. Toxicol. Chem. 30, 548-555. doi: 10.1002/etc.431

Chaufan, G., Coalova, I., and Ríos de Molina, M. C. (2014). Glyphosate commercial formulation causes cytotoxicity, oxidative effects, and apoptosis on human cells: differences with its active ingredient. Int. J. Toxicol. 33, 29-38. doi: $10.1177 / 1091581813517906$

Chen, J., Jiang, C., Huang, H., Wei, S., Huang, Z., Wang, H., et al. (2017). Characterization of Eleusine indica with gene mutation or amplification in EPSPS to glyphosate. Pestic Biochem. Physiol. 143, 201-206. doi: $10.1016 /$ j.pestbp.2017.09.012

Chłopecka, M., Mendel, M., Dziekan, N., and Karlik, W. (2014). Glyphosate affects the spontaneous motoric activity of intestine at very low doses - in vitro study. Pestic Biochem. Physiol. 113, 25-30. doi: 10.1016/j.pestbp.2014.06.005

Chłopecka, M., Mendel, M., Dziekan, N., and Karlik, W. (2017). The effect of glyphosate-based herbicide Roundup and its co-formulant, POEA, on the motoric activity of rat intestine - In vitro study. Environ. Toxicol. Pharmacol. 49, 156-162. doi: 10.1016/j.etap.2016.12.010

Clair, É., Mesnage, R., Travert, C., and Séralini, G.-É. (2012). A glyphosatebased herbicide induces necrosis and apoptosis in mature rat testicular cells in vitro, and testosterone decrease at lower levels. Toxicol. In Vitro 26, 269-279. doi: 10.1016/j.tiv.2011.12.009

Clausing, P., Robinson, C., and Burtscher-Schaden, H. (2018). Pesticides and public health: an analysis of the regulatory approach to assessing the carcinogenicity of glyphosate in the European Union. J. Epidemiol. Commun. 72, 1-5. doi: 10.1136/jech-2017-209776

Coalova, I., Ríos de Molina, M. C., and Chaufan, G. (2014). Influence of the spray adjuvant on the toxicity effects of a glyphosate formulation. Toxicol. In Vitro 28, 1306-1311. doi: 10.1016/j.tiv.2014. 06.014

Conners, D. E., and Black, M. C. (2004). Evaluation of lethality and genotoxicity in the freshwater mussel Utterbackia imbecillis (Bivalvia: Unionidae) exposed singly and in combination to chemicals used in lawn care. Arch. Environ. Contam. Toxicol. 46, 362-371. doi: 10.1007/s00244-003-3003-z

Connolly, A., Jones, K., Galea, K. S., Basinas, I., Kenny, L., McGowan, P., et al. (2017). Exposure assessment using human biomonitoring for glyphosate and fluroxypyr users in amenity horticulture. Int. J. Hyg. Environ. Health 220, 1064-1073. doi: 10.1016/j.ijheh.2017.06.008

Conrad, A., Schröter-Kermani, C., Hoppe, H. W., Rüther, M., Pieper, S., and Kolossa-Gehring, M. (2017). Glyphosate in German adults - Time trend (2001 to 2015) of human exposure to a widely used herbicide. Int. J. Hyg. Environ. Health 220, 8-16. doi: 10.1016/j.ijheh.2016.09.016

Coullery, R. P., Ferrari, M. E., and Rosso, S. B. (2016). Neuronal development and axon growth are altered by glyphosate through a WNT non-canonical signaling pathway. Neuro Toxicol. 52, 150-561. doi: 10.1016/j.neuro.2015.12.004

Coupe, R. H., Kalkhoff, S. J., and Capel, P. D. (2012). Fate and transport of glyphosate and aminomethylphosphonic acid in surface waters of agricultural basins. Pest Manage. Sci. 68, 16-30. doi: 10.1002/ps.2212

Cuhra, M. (2015). Review of GMO safety assessment studies: glyphosate residues in Roundup Ready crops is an ignored issue. Environ. Sci. Eur. 27:20. doi: 10.1186/s12302-015-0052-7

Cuhra, M., Bøhn, T., and Cuhra, P. (2016). Glyphosate: too much of a good thing? Front. Environ. Sci. 4:28. doi: 10.3389/fenvs.2016.00028

Cuhra, M., Traavik, T., and Bøhn, T. (2013). Clone- and age-dependent toxicity of a glyphosate commercial formulation and its active ingredient in Daphnia magna. Ecotoxicol. 22, 251-262. doi: 10.1007/s10646-012-1021-1

Cuhra, M., Traavik, T., Dando, M., Primicerio, R., Holderbaum, D. F., and Bøhn, T. (2015). Glyphosate-residues in Roundup-Ready soybean impair Daphnia magna life-cycle. J. Agric. Chem. Environ. 4, 24-36. doi: $10.4236 /$ jacen.2015.41003

Curwin, B. D., Hein, M. J., Sanderson, W. T., Striley, C., Heederik, D., Kromhout, H., et al. (2007). Urinary pesticide concentrations among children, mothers and fathers living in farm and non-farm households in Iowa. Ann. Occup. Hyg. 51, 53-65. doi: 10.1093/annhyg/mel062

Dai, P., Hu, P., Tang, J., Li, Y., and Li, C. (2016). Effect of glyphosate on reproductive organs in male rat. Acta Histochem. 118, 519-526. doi: 10.1016/j.acthis.2016.05.009

Daouk, S., De Alencastro, L. F., and Pfeifer, H.-R. (2013). The herbicide glyphosate and its metabolite AMPA in the Lavaux vineyard area, western Switzerland: proof of widespread export to surface waters. Part II: The role of infiltration and surface runoff. J. Environ. Sci. Health B 48, 725-736. doi: 10.1080/03601234.2013.780548

Davis, A. M., Thorburn, P. J., Lewis, S. E., Bainbridge, Z. T., Attard, S. J., Milla, R., et al. (2013). Environmental impacts of irrigated sugarcane production: Herbicide run-off dynamics from farms and associated drainage systems. Agric. Ecosyst. Environ. 180, 123-135. doi: 10.1016/j.agee.2011.0 6.019

de Ávila, R. I., Teixeira, G. C., Veloso, D. F. M. C., Moreira, L. C., Lima, E. M., and Valadares, M. C. (2017). In vitro assessment of skin sensitization, photosensitization and phototoxicity potential of commercial glyphosate-containing formulations. Toxicol. In Vitro 45, 386-392. doi: 10.1016/j.tiv.2017.04.001

de Liz Oliveira Cavalli, V. L., Cattani, D., Heinz Rieg, C. E., Pierozan, P., Zanatta, L., Benedetti Parisotto, E., et al. (2013). Roundup disrupts male reproductive functions by triggering calcium-mediated cell death in rat testis and Sertoli cells. Free Radic. Biol. Med. 65, 335-346. doi: 10.1016/j.freeradbiomed.2013.06.043

de Melo, M. I. A., Cunha, P. D. S., da Mata Martins, T. M., Miranda, M. C., Gomes, D. A., Goes, A. M., et al. (2018). Glyphosate-based herbicide induces toxic effects on human adipose-derived mesenchymal stem cells grown in human plasma. Comp. Clin. Pathol. 27, 989-1000. doi: 10.1007/s00580-018-2692-7

de Moura, F. R., da Silva Lima, R. R., da Cunha, A. P. S., da Costa Marisco, P., Aguiar, D. H., Sugui, M. M., et al. (2017). Effects of glyphosate-based herbicide on pintado da Amazônia: hematology, histological aspects, metabolic parameters and genotoxic potential. Environ. Toxicol. Pharmacol. 56, 241-248. doi: 10.1016/j.etap.2017.09.019 
De Roos, A. J., Blair, A., Rusiecki, J. A., Hoppin, J. A., Svec, M., Dosemeci, M., et al. (2005). Cancer incidence among glyphosate-exposed pesticide applicators in the agricultural health study. Environ. Health Perspect. 113, 49-54. doi: 10.1289/ehp.7340

De Roos, A. J., Zahm, S. H., Cantor, K. P., Weisenburger, D. D., Holmes, F. F., Burmeister, L. F., et al. (2003). Integrative assessment of multiple pesticides as risk factors for non-Hodgkin's lymphoma among men. Occup. Environ. Med. 60:e11. doi: 10.1136/oem.60.9.e11

De Souza Filho, J., Sousa, C. C., Da Silva, C. C., De Sabóia-Morais, S. M., and Grisolia, C. K. (2013). Mutagenicity and genotoxicity in gill erythrocyte cells of Poecilia reticulata exposed to a glyphosate formulation. Bull. Environ. Contam. Toxicol. 91, 583-587. doi: 10.1007/s00128-013-1103-7

Defarge, N., Spiroux de Vendômois, J., and Séralini, G. E. (2018). Toxicity of formulants and heavy metals in glyphosate-based herbicides and other pesticides. Toxicol. Res. 5, 156-163. doi: 10.1016/j.toxrep.2017.12.025

Defarge, N., Takács, E., Lozano, V., Mesnage, R., Spiroux de Vendômois, J., Séralini, G.-E., et al. (2016). Co-formulants in glyphosate-based herbicides disrupt aromatase activity in human cells below toxic levels. Int. J. Environ. Res. Public Health 13:264. doi: 10.3390/ijerph13030264

Dennis, P. G., Kukulies, T., Forstner, C., Orton, T. G., and Pattison, A. B. (2018). The effects of glyphosate, glufosinate, paraquat and paraquat-diquat on soil microbial activity and bacterial, archaeal and nematode diversity. Sci. Rep. 8:2119. doi: 10.1038/s41598-018-20589-6

Di Guardo, A., and Finizio, A. (2018). A new methodology to identify surface water bodies at risk by using pesticide monitoring data: The glyphosate case study in Lombardy Region (Italy). Sci. Total Environ. 610-611, 421-429. doi: 10.1016/j.scitotenv.2017.08.049

Dill, G. M., Sammons, R. D., Feng, P. C. C., Kohn, F., Kretzmer, K., Mehrsheikh, A., et al. (2010). "Glyphosate: discovery, development, applications, and properties," in Glyphosate Resistance in Crops and Weeds: History, Development, and Management. ed V. K. Nandula (Hoboken, NJ: Wiley), 1-33.

Dolatabadian, A., Patel, D. A., Edwards, D., and Batley, J. (2017). Copy number variation and disease resistance in plants. Theor. Appl. Genet. 130, 2479-2490. doi: 10.1007/s00122-017-2993-2

dos Santos, A. P., Rocha, T. L., Borges, C. L., Bailão, A. M., de Almeida Soares, C. M., and de Sabóia-Morais, S. M. (2017). A glyphosate-based herbicide induces histomorphological and protein expression changes in the liver of the female guppy Poecilia reticulate. Chemosphere 168, 933-943. doi: 10.1016/j.chemosphere.2016.10.116

Drzyzga, D., and Lipok, J. (2017). Analytical insight into degradation processes of aminopolyphosphonates as potential factors that induce cyanobacterial blooms. Environ. Sci. Pollut. Res. 24, 24364-24375. doi: 10.1007/s11356-017-0068-1

Duke, S. O. (2018). Glyphosate: The world's most successful herbicide under intense scientific scrutiny. Pest Manage. Sci. 74, 1025-1026. doi: $10.1002 /$ ps.4902

Edwards, W. M., Triplett, G. B., and Kramer, R. M. (1980). A watershed study of glyphosate transport in runoff. J. Environ. Qual. 9, 661-665. doi: 10.2134/jeq1980.00472425000900040024x

Elie-Caille, C., Heu, C., Guyon, C., and Nicod, L. (2010). Morphological damages of a glyphosate-treated human keratinocyte cell line revealed by a micro- to nanoscale microscopic investigation. Cell Biol. Toxicol. 26, 331-339. doi: 10.1007/s10565-009-9146-6

El-Shenawy, N. S. (2009). Oxidative stress responses of rats exposed to Roundup and its active ingredient glyphosate. Environ. Toxicol. Pharmacol. 28, 379-385. doi: 10.1016/j.etap.2009.06.001

Elsner, P., Darr-Foit, D., and Schliemann, S. (2018). Occupational koebnerization of psoriasis caused by glyphosate. J. Deutsch Dermat Ges. 16, 70-71. doi: $10.1111 / \mathrm{ddg} .13393$

Erickson, B. (2017). Glyphosate Renewed for Five Years in the EU. Chem Eng News 95, 16. Available online at: http://pubs.acs.org/doi/abs/10.1021/cen-09548notw11

Erickson, B. (2018). California glyphosate warning requirement on hold. Chem. Eng. News. 96:14. doi: 10.1021/cen-09610-polcon8

Eriksson, M., Hardell, L., and Carlberg, M., Åkerm, M. (2008). Pesticide exposure as risk factor for non-Hodgkin lymphoma including histopathological subgroup analysis. Int. J. Cancer 123, 1657-1663. doi: 10.1002/ijc.23589
European Chemicals Agency (2017a). Glyphosate Not Classified as a Carcinogen by ECHA. ECHA/PR/17/06. Mar 15, 2017. Available online at: https://echa.europa. eu/-/glyphosate-not-classified-as-a-carcinogen-by-echa

European Chemicals Agency (2017b). Opinion Proposing Harmonised Classification and Labeling at EU Level of Glyphosate (ISO); N(phosphonomethyl)Glycine. CLH-O-0000001412-86-149/F. Available online at: https://echa.europa.eu/documents/10162/2d3a87cc-5ca1-31d6-89679f124f1ab7ae

European Commission (1991). Council Directive 91/414/EEC of 15 July 1991 Concerning the Placing of Plant Protection Products on the Market. OJ L230:1-32. Available online at: http://eur-lex.europa.eu/legal-content/EN/ TXT/?uri=CELEX:31991L0414

European Commission (2000). Directive 2000/60/EC of 23 October 2000 Establishing a Framework for Community Action in the Field of Water Policy. OJ L327:1-73. Available online at: http://eur-lex.europa.eu/legal-content/EN/ $\mathrm{TXT} /$ ?uri=celex\%3A32000L0060

European Commission (2001). Commission Directive 2001/99/EC 20 November 2001 Amending Annex I to Council Directive 91/414/EEC Concerning the Placing of Plant Protection Products on the Market to Include Glyphosate and Thifensulfuron-methyl as Active Substances. OJ L304:14-16. Available online at: http://eur-lex.europa.eu/legal-content/EN/TXT/?uri=CELEX:32001L0099

European Commission (2009). Regulation 1107/2009 of the European Parliament and of the Council of 21 October 2009 Concerning the Placing of Plant Protection Products on the Market and Repealing Council Directives 79/117/EEC and 91/414/EEC. OJ L309:1-50. Available onlilne at: http://eurlex.europa.eu/legal-content/EN/TXT/?uri=CELEX:32009R1107

European Commission (2010). Commission Directive 2010/77/EU of 10 November 2010 amending Council Directive 91/414/EEC as Regards the Expiry Dates for Inclusion in Annex I of Certain Active Substances. OJ L293:48-57. Available online at: http://eur-lex.europa.eu/legal-content/EN/ TXT/?uri=CELEX:32010L0077

European Commission (2011a). Commission Implementing Regulation Renewing Renewing the Approval of the Active Substance Glyphosate In Accordance With Regulation (Ec) No 1107/2009 of the European Parliament and of the Council Concerning The Placing of Plant Protection Products on the Market, and Amending The Annex to Implementing Regulation (Eu) No 540/. Available online at: https://ec.europa.eu/food/sites/food/files/plant/docs/ pesticides_glyphosate_commission_prpposal_revision4.pdf

European Commission (2011b). Commission Implementing Regulation (EU) No 540/2011 of 25 May 2011 implementing Regulation (EC) No 1107/2009 of the European Parliament and of the Council as regards the list of approved active substances. OJ L153:1-186. Available online at: http://eur-lex.europa.eu/legalcontent/EN/TXT/?uri=CELEX:32011R0540

European Commission (2016a). Fact Sheet. FAQs: Glyphosate. European Commission, Brussels. Available online at: http://europa.eu/rapid/pressrelease_MEMO-16-2012_en.htm

European Commission (2016b). Implementing Regulation (EU) 2016/1313 of 1 August 2016 Amending Implementation Regulation (EU) No 540/2011 as Regards the Conditions of Approval of the Active Substance Glyphosate. OJ L208:1. Available online at: http://eur-lex.europa.eu/legal-content/EN/TXT/? uri=uriserv\%3AOJ.L_.2016.208.01.0001.01.ENG

European Commission (2017). Implementing Regulation (EU) 2017/2324 of 12 December 2017 Renewing the Approval of the Active Substance Glyphosate in Accordance With Regulation (EC) No 1107/2009 of the European Parliament and of the Council Concerning the Placing of Plant Protection Products on the Market, and Amending the Annex to Commission Implementing Regulation (EU) No 540/2011. OJ L333:10-16. Available online at: http://eur-lex.europa. eu/legal-content/EN/TXT/PDF/?uri=CELEX:32017R2324

European Food Safety Authority (2015a). Conclusion on the peer review of the pesticide risk assessment of the active substance glyphosate. EFSA J. 13:4302. doi: $10.2903 /$ j.efsa.2015.4302

European Food Safety Authority (2015b). Peer Review Report on Glyphosate. EFSA, Parma. Available online at: https://corporateeurope.org/sites/default/ files/attachments/4302prr_public.pdf

European Food Safety Authority (2015c). Request for the evaluation of the toxicological assessment of the co-formulant POE-tallowamine. EFSA J. 13:4303. doi: $10.2903 /$ j.efsa.2015.4303 
European Food Safety Authority (2016). Glyphosate: EFSA Shares Raw Data From Risk Assessment. EFSA, Parma. Available online at: https://www.efsa.europa.eu/ en/press/news/161209

European Food Safety Authority (2017a). Peer review of the pesticide risk assessment of the potential endocrine disrupting properties of glyphosate. EFSA J. 15:497913. doi: 10.2903/j.efsa.2017.4979

European Food Safety Authority (2017b). The 2015 European Union report on pesticide residues in food. EFSA J. 15:4791. doi: 10.2903/j.efsa.2017.4791

European Food Safety Authority (2018a). Evaluation of the impact of glyphosate and its residues in feed on animal health. EFSA J. 16:5283. doi: $10.2903 /$ j.efsa.2018.5283

European Food Safety Authority (2018b). Review of the existing maximum residue levels for glyphosate according to Article 12 of Regulation (EC) No 396/2005. EFSA J. 16:5263. doi: 10.2903/j.efsa.2018.5263

European Parliament and Council, K. (2006). P. Directive 2006/118/EC of 12 December 2006 on the Protection of Groundwater Against Pollution and Deterioration. OJ L372:19-31. Available online at: http://eur-lex.europa.eu/ legal-content/EN/TXT/?uri=LEGISSUM:128139

European Parliament and Council (1976). Council Directive 76/464/EEC of 4 May 1976 on Pollution Caused by Certain Dangerous Substances Discharged Into the Aquatic Environment of the Community. OJ L129:23-29. Available online at: http://eur-lex.europa.eu/legal-content/EN/ALL/?uri=CELEX \%3A31976L0464

European Parliament and Council (1998). Council Directive of 98/83/EC of 3 November 1998 on the Quality of water Intended for Human Consumption. OJ L330:32-54. Available online at: http://eur-lex.europa.eu/legal-content/EN/ TXT/?uri=CELEX\%3A31998L0083

European Parliament and Council (2002). Laying down the General Principles and Requirements of Food Law, establishing the European Food Safety Authority and Laying Down Procedures in Matters of Food Safety. 178/2002/EC Regulation. OJ L031. Available online at: http://eurlex.europa.eu/LexUriServ/ LexUriServ.do?uri=OJ:L:2002:031:0001:0024:en:PDF

European Parliament, and Council (2008). Directive 2008/105/EC of 16 December 2008 on Environmental Quality Standards in the Field of Water Policy, Amending and Subsequently Repealing Council Directives 82/176/EEC, 83/513/EEC, 84/156/EEC, 84/491/EEC, 86/280/EEC and Amending Directive 2000/60/EC of the European Parliament and of the Council. OJ L348:84-97. Available online at: http://eur-lex.europa.eu/legal-content/EN/TXT/?uri= uriserv:OJ.L_.2008.348.01.0084.01.ENG

Farkas, E., Szekacs, A., Kovacs, B., Olah, M., Horvath, R., and Szekacs, I. (2018). Label-free optical biosensor for real-time monitoring the cytotoxicity of xenobiotics: a proof of principle study on glyphosate. J. Hazard Mater. 351, 80-89. doi: 10.1016/j.jhazmat.2018.02.045

Feng, J. C., Thompson, D. G., and Reynolds, P. E. (1990). Fate of glyphosate in a Canadian forest watershed. 1. Aquatic residues and off-target deposit assessment. J. Agric. Food Chem. 38, 1110-1118. doi: 10.1021/jf00094a045

Fernandez-Escalada, M., Zulet-Gonzalez, A., Gil-Monreal, M., Zabalza, A., Ravet, K., Gaines, T., et al. (2017). Effects of EPSPS copy number variation (CNV) and glyphosate application on the aromatic and branched chain amino acid synthesis pathways in Amaranthus palmeri. Front. Plant Sci. 8:1970. doi: $10.3389 /$ fpls.2017.01970

Ferreira-Junior D. F., Sarmento, R. A., Saraiva de Souza, A., Pereira, R. R., Picanço, M. C., Pestana, J. L. T., and Soares, A. M. V. M. (2017). Low concentrations of glyphosate-based herbicide affects the development of Chironomus xanthus. Water Air Soil Pollut. 228:390. doi: 10.1007/s11270-017-3536-9

Fiorino, E., Sehonova, P., Plhalova, L., Blahova, J., Svobodova, Z., and Faggio, C. (2018). Effects of glyphosate on early life stages: comparison between Cyprinus carpio and Danio rerio. Environ. Sci. Pollut. Res. 25, 8542-8549. doi: 10.1007/s11356-017-1141-5

Food and Agriculture Organization of the United Nations (2011). Glyphosate. In: Pesticide residues in food - 2011. Report of the Joint Meeting of the FAO Panel of Experts on Pesticide Residues in Food and the Environment and the WHO Expert Group on Pesticide Residues. FAO Plant Production and Protection Paper 211:155-171. Available online at: http://apps.who.int/iris/ bitstream/handle/10665/75147/9789241665278_eng.pdf

Ford, B., Bateman, L. A., Gutierrez-Palominos, L., Park, R., and Nomura, D. K. (2017). Mapping proteome-wide targets of glyphosate in mice. Cell Chem. Biol. 24, 133-140. doi: 10.1016/j.chembiol.2016.12.013
Foucart, S. (2016). La discrète Influence de Monsanto. Le Monde Sci Techno 11.07.2016. Available online at: http://www.lemonde.fr/sciences/article/2016/ 07/11/la-discrete-influence-de-monsanto_4967784_1650684.html

Foucart, S., and Horel, S. (2018). Food safety: risk of glyphosate flagged. Nature 555:443. doi: 10.1038/d41586-018-03394-z

Franz, J. (1974). N-phosphonomethyl-glycine phytotoxicant compositions. US Patent 3799758. Int. Cl. A01n 9/36. United States Patent Office. Mar 26, (Application: Aug 9, 1971). Available online at: https://patentimages.storage. googleapis.com/pdfs/US3799758.pdf

Gandhi, J. S., and Cecala, K. K. (2016). Interactive effects of temperature and glyphosate on the behavior of blue ridge two-lined salamanders (Eurycea wilderae). Environ. Toxicol. Chem. 35, 2297-2303. doi: 10.1002/ etc. 3398

García-Espiñeira, M., Tejeda-Benitez, L., and Olivero-Verbel, J. (2018). Toxicity of atrazine- and glyphosate-based formulations on Caenorhabditis elegans. Ecotoxicol. Environ. Saf. 156, 216-222. doi: 10.1016/j.ecoenv.2018.02.075

Gasnier, C., Benachour, N., Clair, E., Travert, C., Langlois, F., Laurant, C., et al. (2010). Dig1 protects against cell death provoked by glyphosatebased herbicides in human liver cell lines. J. Occup. Med. Toxicol. 5:29. doi: 10.1186/1745-6673-5-29

Gasnier, C., Dumont, C., Benachour, N., Clair, E., Chagnon, M., and Séralini, G. E. (2009). Glyphosate-based herbicides are toxic and endocrine disruptors in human cell lines. Toxicol 262, 184-191. doi: 10.1016/j.tox.2009.06.006

Gaupp-Berghausen, M., Hofer, M., Rewald, B., and Zaller, J. G. (2015). Glyphosatebased herbicides reduce the activity and reproduction of earthworms and lead to increased soil nutrient concentrations. Sci. Rep. 5:12886. doi: $10.1038 /$ srep 12886

German Federal Institute for Risk Assessment (2013). Renewal Assessment Report (RAR) on the Active Substance Glyphosate Prepared by the Rapporteur Member State Germany in the Framework of Regulation (EU) No 1141/2010.

German Federal Institute for Risk Assessment (2015). Final Addendum to the Renewal Assessment Report. Risk Assessment Provided by the Rapporteur Member State Germany and Co-Rapporteur Member State Slovakia for the Active Substance Glyphosate According to the Procedure for the Renewal of the Inclusion of a Second Group of Active Substances in Annex I to Council Directive 91/414/EEC laid down in Commission Regulation (EU) No. 1141/2010. Available online at: https://echa.europa.eu/documents/10162/ 13626/renewal_assessment_report_addenda_en.pdf

Ghisi, N. C., and Cestari, M. M. (2013). Genotoxic effects of the herbicide Roundup ${ }^{\circledR}$ in the fish Corydoras paleatus (Jenyns 1842) after short-term, environmentally low concentration exposure. Environ. Monit. Assess 185, 3201-3207. doi: 10.1007/s10661-012-2783-x

Ghisi, N. C., Oliveira, E. C., and Prioli, A. J. (2016). Does exposure to glyphosate lead to an increase in the micronuclei frequency? A systematic and meta-analytic review. Chemosphere 145, 42-54. doi: 10.1016/j.chemosphere.2015.11.044

Gholami-Seyedkolaei, S. J., Mirvaghefi, A., Farahmand, H., and Kosari, A. A. (2013). Effect of a glyphosate-based herbicide in Cyprinus carpio: assessment of acetylcholinesterase activity, hematological responses and serum biochemical parameters. Ecotoxicol. Environ. Saf. 98, 135-141. doi: 10.1016/j.ecoenv.2013.09.011

Gill, J. P. K., Sethi, N., Mohan, A., Datta, S., and Girdhar, M. (2018). Glyphosate toxicity for animals. Environ. Chem. Lett. 16, 401-426. doi: 10.1007/s10311-017-0689-0

Glozier, N. E., Struger, J., Cessna, A. J., Gledhill, M., Rondeau, M., Ernst, W. R., et al. (2012). Occurrence of glyphosate and acidic herbicides in select urban rivers and streams in Canada, 2007. Environ. Sci. Pollut. Res. 19, 821-834. doi: 10.1007/s11356-011-0600-7

Gonçalves, B. B., Nascimento, N. F., Santos, M. P., Bertolini, R. M., Yasui, G. S., and Giaquinto, P. C. (2018). Low concentrations of glyphosate-based herbicide cause complete loss of sperm motility of yellowtail tetra fish Astyanax lacustris. J. Fish Biol. 92, 1218-1224. doi: 10.1111/jfb.13571

Goulart, T. L. S., Boyle, R. T., and Souza, M. M. (2015). Cytotoxicity of the association of pesticides Roundup Transorb ${ }^{\circledR}$ and Furadan 350 $\mathrm{SC}^{\circledR}$ on the zebrafish cell line, ZF-L. Toxicol. In Vitro 29, 1377-1384. doi: 10.1016/j.tiv.2015.06.007

Gress, S., Lemoine, S., Séralini, G. E., and Puddu, P. E. (2015). Glyphosatebased herbicides potently affect cardiovascular system in mammals: review 
of the literature. Cardiovasc. Toxicol. 15, 117-126. doi: 10.1007/s12012-014-9 282-y

Guerrero Schimpf, M., Milesi, M. M., Ingaramo, P. I., Luque, E. H., and Varayoud, J. (2017). Neonatal exposure to a glyphosate based herbicide alters the development of the rat uterus. Toxicology 376, 2-14. doi: 10.1016/j.tox.2016.06.004

Guilherme, S., Gaivão, I., Santos, M. A., and Pacheco, M. (2010). European eel (Anguilla anguilla) genotoxic and pro-oxidant responses following shortterm exposure to Roundup ${ }^{\circledR}$ - a glyphosate-based herbicide. Mutagenesis 25, 523-530. doi: 10.1093/mutage/geq038

Guilherme, S., Santos, M. A., Gaivão, I., and Pacheco, M. (2014a). Are DNA-damaging effects induced by herbicide formulations (Roundup ${ }^{\circledR}$ and Garlon ${ }^{\circledR}$ ) in fish transient and reversible upon cessation of exposure? Aquat. Toxicol. 155, 213-221. doi: 10.1016/j.aquatox.2014.06.007

Guilherme, S., Santos, M. A., Gaivão, I., and Pacheco, M. (2014b). DNA and chromosomal damage induced in fish (Anguilla anguilla L.) by aminomethylphosphonic acid (AMPA)-the major environmental breakdown product of glyphosate. Environ. Sci. Pollut. Res. Int. 21, 8730-8739. doi: 10.1007/s11356-014-2803-1

Guyton, K. Z., Loomis, D., Grosse, Y., El Ghissassi, F., BenbrahimTallaa, L., Guha, N., et al. (2015). Carcinogenicity of tetrachlorvinphos, parathion, malathion, diazinon, and glyphosate. Lancet Oncol. 16, 490-491. doi: 10.1016/S1470-2045(15)70134-8

Hamdaoui, L., Naifar, M., Mzid, M., Ben Salem, M., Chtourou, A., MakniAyadi, F., et al. (2016). Nephrotoxicity of Kalach 360 SL: biochemical and histopathological findings. Toxicol. Mech. Methods 26, 685-691. doi: 10.1080/15376516.2016.1230918

Han, H., Vila-Aiub, M. M., Jalaludin, A., Yu, Q., and Powles, S. B. (2017). A double EPSPS gene mutation endowing glyphosate resistance shows a remarkably high resistance cost. Plant Cell Environ. 40, 3031-3042. doi: 10.1111/pce.13067

Hanke, I., Wittmer, I., Bischofberger, S., Stamm, C., and Singer, H. (2010). Relevance of urban glyphosate use for surface water quality. Chemosphere 81, 422-429. doi: 10.1016/j.chemosphere.2010.06.067

Harayashiki, C. A., Varela, A. S. Jr, Machado, A. A., Cabrera Lda, C., Primel, E. G., Bianchini, A., et al. (2013). Toxic effects of the herbicide Roundup in the guppy Poecilia vivipara acclimated to fresh water. Aquat. Toxicol 142-143, 176-184. doi: 10.1016/j.aquatox.2013.08.006

Hardell, L., and Eriksson, M. (1999). A case-control study of non-Hodgkin lymphoma and exposure to pesticides. Cancer 85, 1353-1360. doi: 10.1002/ (SICI)1097-0142(19990315)85:6<1353::AID-CNCR19>3.0.CO;2-1

Hardell, L., Eriksson, M., and Nordstrom, M. (2002). Exposure to pesticides as risk factor for non-Hodgkin's lymphoma and hairy cell leukemia: pooled analysis of two Swedish case-control studies. Leuk Lymphoma 43, 1043-1049. doi: 10.1080/10428190290021560

Haskovic, E., Pekic, M., Focak, M., Suljevi,ć, D., and Mešali,ć, L. (2016). Effects of glyphosate on enzyme activity and serum glucose in rats Rattus norvegicus. Acta Vet Beograd. 66, 214-221. doi: 10.1515/acve-2016-0018

Heinemann, J. A., Massaro, M., Coray, D. S., Agapito-Tenfen, S. Z., and Wen, J. D. (2014). Sustainability and innovation in staple crop production in the US Midwest. Int. J. Agric. Sust. 12, 71-88. doi: 10.1080/14735903.2013. 806408

Henao Muñoz, L. M., Montes Rojas, C. M., and Bernal Bautista, M. H. (2015). Acute toxicity and sublethal effects of the mixture glyphosate (Roundup Active) and Cosmo-Flux $411 \mathrm{~F}$ to anuran embryos and tadpoles of four Colombian species. Rev. Biol. Trop. 63, 223-233. doi: 10.15517/rbt.v63i1. 12893

Heras-Mendaza, F., Casado-Fariñas, I., Paredes-Gascón, M., and Conde-Salazar, L. (2008). Erythema multiforme-like eruption due to an irritant contact dermatitis from a glyphosate pesticide. Contact Dermatitis 59, 54-56. doi: 10.1111/j.1600-0536.2007.01307.x

Héritier, L., Duval, D., Galinier, R., Meistertzheim, A. L., and Verneau, O. (2017). Oxidative stress induced by glyphosate-based herbicide on freshwater turtles. Environ. Toxicol. Chem. 36, 3343-3350. doi: 10.1002/etc.3916

Hernández-Plata, I., Giordano, M., Díaz-Muñoz, M., and Rodríguez, V. M. (2015). The herbicide glyphosate causes behavioral changes and alterations in dopaminergic markers in male Sprague-Dawley rat. Neurotoxicology 46, 79-91. doi: 10.1016/j.neuro.2014.12.001
Heu, C., Berquand, A., Elie-Caille, C., and Nicod, L. (2012a). Glyphosate-induced stiffening of HaCaT keratinocytes, a Peak Force Tapping study on living cells. J. Struct. Biol. 178, 1-7. doi: 10.1016/j.jsb.2012.02.007

Heu, C., Elie-Caille, C., Mougey, V., Launay, S., and Nicod, L. (2012b). A step further toward glyphosate-induced epidermal cell death: involvement of mitochondrial and oxidative mechanisms. Environ. Toxicol. Pharmacol. 34, 144-153. doi: 10.1016/j.etap.2012.02.010

Hong, Y., Yang, X., Yan, G., Huang, Y., Zuo, F., Shen, Y., et al. (2017). Effects of glyphosate on immune responses and haemocyte DNA damage of Chinese mitten crab, Eriocheir sinensis. Fish Shellfish Immunol. 71, 19-27. doi: 10.1016/j.fsi.2017.09.062

Huhn, C. (2018). More and enhanced glyphosate analysis is needed. Anal. Bioanal. Chem. 410, 3041-3045. doi: 10.1007/s00216-018-1000-3

Huntscha, S., Stravs, M. A., Bühlmann, A., Ahrens, C. H.,Frey, J. E., Pomati, F. et al. (2018). Seasonal dynamics of glyphosate and AMPA in Lake Greifensee: rapid microbial degradation in the epilimnion during summer. Environ. Sci. Technol. 52, 4641-4649. doi: 10.1021/acs.est.8b00314

Ibánez, M., Pozo, Ó. J., Sancho, J. V., López, F. J., and Hernández, F. (2006). Re-evaluation of glyphosate determination in water by liquid chromatography coupled to electrospray tandem mass spectrometry. J. Chromatogr. A 1134, 51-55. doi: 10.1016/j.chroma.2006.07.093

Infante, P. F., Melnick, R., Huff, J., and Vainio, H. (2018). Commentary: IARC Monographs Program and public health under siege by corporate interests. Am. J. Ind. Med. 61, 277-281. doi: 10.1002/ajim.22811

InfoCuria (2017). Court of Justice of the European Union. Stichting Greenpeace Nederland and PAN Europe v Commission. Case T-545/11 RENV. Available online at: http://curia.europa.eu/juris/liste.jsf?num=T-545/11

Ingaramo, P. I., Varayoud, J., Milesi, M. M., Guerrero Schimpf, M., Alarcón, R., Muñoz-de-Toro, M., et al. (2017). Neonatal exposure to a glyphosate-based herbicide alters uterine decidualization in rats. Reprod. Toxicol. 73, 87-95. doi: 10.1016/j.reprotox.2017.07.022

Ingaramo, P. I., Varayoud, J., Milesi, M. M., Schimpf, M. G., Muñoz-de-Toro, M., and Luque, E. H. (2016). Effects of neonatal exposure to a glyphosatebased herbicide on female rat reproduction. Reproduction 152, 403-415. doi: 10.1530/REP-16-0171

International Agency for Research on Cancer (2015). Some Organophosphate Insecticides and Herbicides: Diazinon, Glyphosate, Malathion, Parathion, and Tetrachlorvinphos. Glyphosate Lyon: IARC. 1-92. Available online at: http:// monographs.iarc.fr/ENG/Monographs/vol112/mono112-10.pdf

International Agency for Research on Cancer (2017). Some Organophosphate Insecticides and Herbicides. IARC Monographs on the Evaluation of Carcinogenic Risks to Humans 112, 1-452. Available online at: http://monographs.iarc.fr/ ENG/Monographs/vol112/mono112.pdf

James, C. (2015). Global Status of Commercialized Biotech/GM Crops: 2015. ISAAA Brief No. 51. Ithaca, NY: International Service for the Acquisition of Agri-biotech Applications Available online at: http://www.isaaa.org/resources/ publications/briefs/51

Janssens, L., and Stoks, R. (2017). Stronger effects of Roundup than its active ingredient glyphosate in damselfly larvae. Aquat. Toxicol. 193, 210-216. doi: 10.1016/j.aquatox.2017.10.028

Jayasumana, C., Gunatilake, S., and Senanayake, P. (2014). Glyphosate, hard water and nephrotoxic metals: are they the culprits behind the epidemic of chronic kidney disease of unknown etiology in Sri Lanka? Int. J. Environ. Res. Public Health 11, 2125-2147. doi: 10.3390/ijerph110202125

Jayasumana, C., Gunatilake, S., and Siribaddana, S. (2015). Simultaneous exposure to multiple heavy metals and glyphosate may contribute to Sri Lankan agricultural nephropathy. BMC Nephrol. 16:103. doi: 10.1186/s12882-015-0109-2

Jin, J., Kurobe, T., Ramírez-Duarte, W. F., Bolotaolo, M. B., Lam, C. H., Pandey, P. K., et al. (2018). Sub-lethal effects of herbicides penoxsulam, imazamox, fluridone and glyphosate on Delta Smelt (Hypomesus transpacificus). Aquat. Toxicol. 197, 79-88. doi: 10.1016/j.aquatox.2018.01.019

Jofré, D. M., Germanó García, M. J., Salcedo, R., Morales, M., Alvarez, M., Enriz, D., et al. (2013). Fish toxicity of commercial herbicides formulated with glyphosate. J. Environ. Anal. Toxicol. 4:199. doi: 10.4172/2161-0525.1000199

Johnston, I. (2017). EU experts accused of conflict of interest over herbicide linked to cancer. The Independent, Mar 7, 2017. London. Available online at: http://www. 
independent.co.uk/environment/glyphosate-roundup-weedkiller-cancerbees-farming-greenpeace-echa-european-chemicals-agency-a 7614736 .html Joint FAO/WHO Meeting on Pesticide Residues (2016). Summary Report. Available online at: http://www.who.int/foodsafety/jmprsummary2016.pdf

Jönsson, J., Camm, R., and Hall, T. (2013). Removal and degradation of glyphosate in water treatment: a review. Aqua 62, 395-408. doi: 10.2166/aqua.2013.080

Jugulam, M., and Gill, B. S. (2018). Molecular cytogenetics to characterize mechanisms of gene duplication in pesticide resistance. Pest Manage Sci. 74, 22-29. doi: $10.1002 /$ ps.4665

Kaiser, K. (2011). Preliminary study of pesticide drift into the Maya Mountain protected areas of Belize. Bull. Environ. Contam. Toxicol. 86, 56-59. doi: 10.1007/s00128-010-0167-x

Kašuba, V., Milić, M., Rozgaj, R., Kopjar, N., Mladinić, M., Žunec, S., et al. (2017). Effects of low doses of glyphosate on DNA damage, cell proliferation and oxidative stress in the HepG2 cell line. Environ. Sci. Pollut. Res. 24, 19267-19281. doi: 10.1007/s11356-017-9438-y

Kier, L. D. (2015). Review of genotoxicity biomonitoring studies of glyphosate-based formulations. Crit. Rev. Toxicol. 45, 209-218. doi: 10.3109/10408444.2015.1010194

Kier, L. D., and Kirkland, D. J. (2013). Review of genotoxicity studies of glyphosate and glyphosate-based formulations. Crit. Rev. Toxicol. 43, 283-315. doi: 10.3109/10408444.2013.770820

Kim, G., Clarke, C. R., Larose, H., Tran, H. T., Haak, D. C., Zhang, L., et al. (2017). Herbicide injury induces DNA methylome alterations in Arabidopsis. PeerJ 5:e3560. doi: 10.7717/peerj.3560

Kim, Y.-H., Hong, J.-R., Gil, H.-W., Song, H.-Y., and Hong, S.-Y. (2013). Mixtures of glyphosate and surfactant TN20 accelerate cell death via mitochondrial damage-induced apoptosis and necrosis. Toxicol. In Vitro 27, 191-197. doi: 10.1016/j.tiv.2012.09.021

Kissane, Z., and Shephard, J. M. (2017). The rise of glyphosate and new opportunities for biosentinel early-warning studies. Conserv. Biol. 31, 1293-1300. doi: 10.1111/cobi.12955

Kjaer, J., Olsen, P., Ullum, M., and Grant, R. (2005). Leaching of glyphosate and amino-methylphosphonic acid from Danish agricultural field sites. J. Environ. Qual. 34, 608-620. doi: 10.2134/jeq2005.0608

Klátyik S. Z., Bohus, P., Darvas, B., and Székács, A. (2017a). Authorization and toxicity of veterinary drugs and plant protection products: residues of the active ingredients in food and feed and toxicity problems related to adjuvants. Front. Vet Sci. 4:146. doi: 10.3389/fvets.2017.00146

Klátyik, S. Z., Takács, E., Mörtl, M., Földi, A., Trábert. Z. S, Ács, É., and Darvas, B., Székács, A. (2017b). Dissipation of the herbicide active ingredient glyphosate in natural water samples in the presence of biofilms. Int. J. Environ. Anal. Chem. 97, 901-921. doi: 10.1080/03067319.2017.1373770

Kniss, A. R. (2017). Long-term trends in the intensity and relative toxicity of herbicide use. Nat. Commun. 8:14865. doi: 10.1038/ncomms14865

Knudsen, L. E., Hansen, P. W., Mizrak, S., Hansen, H. K., Mørck, T. A., Nielsen, F., et al. (2017). Biomonitoring of Danish school children and mothers including biomarkers of PBDE and glyphosate. Rev. Environ. Health 32, 279-290. doi: 10.1515/reveh-2016-0067

Koller, V. J., Fürhacker, M., Nersesyan, A., Mišík, M., Eisenbauer, M., and Knasmueller, S. (2012). Cytotoxic and DNA-damaging properties of glyphosate and Roundup in human-derived buccal epithelial cells. Arch. Toxicol. 86, 805-813. doi: 10.1007/s00204-012-0804-8

Kolpin, D. W., Thurman, E. M., Lee, E. A., Meyer, M. T., Furlong, E. T., and Glassmeyer, S. T. (2006). Urban contributions of glyphosate and its degradate AMPA to streams in the United States. Sci. Total Environ. 354, 191-197. doi: 10.1016/j.scitotenv.2005.01.028

Kondera, E., Teodorczuk, B., and Ługowska, K., Witeska, M. (2018). Effect of glyphosate-based herbicide on hematological and hemopoietic parameters in common carp (Cyprinus carpio L). Fish Physiol. Biochem. 44, 1011-1018. doi: 10.1007/s10695-018-0489-x

Krüger, M., Schledorn, P., Schrödl, W., Hoppe, H. W., Lutz, W., and Shehata, A. A. (2014). Detection of Glyphosate Residues in Animals and Humans. J. Environ. Anal. Toxicol. 4:210. doi: 10.4172/2161-0525.1000210

Kumar, S., Khodoun, M., Kettleson, E. M., McKnight, C., Reponen, T., Grinshpun, S. A., et al. (2014). Glyphosate-rich air samples induce IL-33, TSLP and generate IL-13 dependent airway inflammation. Toxicol 325, 42-51. doi: 10.1016/j.tox.2014.08.008
Kurenbach, B., Gibson, P. S., Hill, A. M., Bitzer, A. S., Silby, M. W., Godsoe, W., et al. (2017). Herbicide ingredients change Salmonella enterica sv. Typhimurium and Escherichia coli antibiotic responses. Microbiology 163, 1791-1801. doi: 10.1099/mic.0.000573

Kwiatkowska, M., Huras, B., and Bukowska, B. (2014). The effect of metabolites and impurities of glyphosate on human erythrocytes (in vitro). Pestic. Biochem. Physiol. 109, 34-43. doi: 10.1016/j.pestbp.2014.01.003

Kwiatkowska, M., Jarosiewicz, P., Michałowicz, J., Koter-Michalak, M., Huras, B., and Bukowska, B. (2016). The impact of glyphosate, its metabolites and impurities on viability, ATP level and morphological changes in human peripheral blood mononuclear cells. PLOS ONE 11:e0156946. doi: 10.1371/journal.pone.0156946

Kwiatkowska, M., Reszka, E., Wozniak, K., Jabłonska, E., Michałowicz, J., and Bukowska, B. (2017). DNA damage and methylation induced by glyphosate in human peripheral blood mononuclear cells (in vitro study). Food Chem. Toxicol. 105, 93-98. doi: 10.1016/j.fct.2017.03.051

la Cecilia, D., and Maggi, F. (2018). Analysis of glyphosate degradation in a soil microcosm. Environ. Pollut. 233, 201-207. doi: 10.1016/j.envpol.2017.10.017

Lajmanovich, R. C., Attademo, A. M., Peltzer, P. M., Junges, C. M., and Cabagna, M. C. (2011). Toxicity of four herbicide formulations with glyphosate on Rhinella arenarum (Anura: Bufonidae) tadpoles: B-esterases and glutathione S-transferase inhibitors. Arch. Environ. Contam. Toxicol. 60, 681-689. doi: 10.1007/s00244-010-9578-2

Lajmanovich, R. C., Cabagna-Zenklusen, M. C., Attademo, A. M., Junges, C. M., Peltzer, P. M., Bassó, A., et al. (2014). Induction of micronuclei and nuclear abnormalities in tadpoles of the common toad (Rhinella arenarum) treated with the herbicides Liberty ${ }^{\circledR}$ and glufosinate-ammonium. Mutat. Res. Genet. Toxicol. Environ. Mutagen 769, 7-12. doi: 10.1016/j.mrgentox.2014.04.009

Lajmanovich, R. C., Junges, C. M., Attademo, A. M., Peltzer, P. M., CabagnaZenklusen, M. C., and Basso, A. (2013). Individual and mixture toxicity of commercial formulations containing glyphosate, metsulfuron-methyl, bispyribac-sodium, and picloram on Rhinella arenarum tadpoles. Water Air Soil Pollut. 224:1404. doi: 10.1007/s11270-012-1404-1

Lajmanovich, R. C., Sandoval, M. T., and Peltzer, P. M. (2003). Induction of mortality and malformation in Scinax nasicus tadpoles exposed to glyphosate formulations. Bull. Environ. Contam. Toxicol. 70, 612-618. doi: 10.1007/s00128-003-0029-x

Landry, D., Dousset, S., Fournier, J.-C., and Andreux, F. (2005). Leaching of glyphosate and AMPA under two soil management practices in Burgundy vineyards (Vosne-Romanée, 21-France). Environ. Pollut. 138, 191-200. doi: 10.1016/j.envpol.2005.04.007

Larsen, K., Najle, R., Lifschitz, A., and Virkel, G. (2012). Effects of sublethal exposure of rats to the herbicide glyphosate in drinking water: glutathione transferase enzyme activities, levels of reduced glutathione and lipid peroxidation in liver, kidneys and small intestine. Environ. Toxicol. Pharmacol. 34, 811-818. doi: 10.1016/j.etap.2012.09.005

Latorre, M. A., López González, E. C., Larriera, A., Poletta, G. L., and Siroski, P. A. (2013). Effects of in vivo exposure to Roundup ${ }^{\circledR}$ on immune system of Caiman latirostris. J. Immunotoxicol. 10, 349-354. doi: 10.3109/1547691X.2012.747233

Lefrancq, M., Jadas-Hécart, A., La Jeunesse, I., Landry, D., and Payraudeau, S. (2017). High frequency monitoring of pesticides in runoff water to improve understanding of their transport and environmental impacts. Sci. Total Environ. 587-588, 75-86. doi: 10.1016/j.scitotenv.2017.02.022

Leveroni, F. A., Caffetti, J. D., and Pastori, M. C. (2017). Genotoxic response of blood, gill and liver cells of Piaractus mesopotamicus after an acute exposure to a glyphosate-based herbicide. Caryologia 70, 21-28. doi: 10.1080/00087114.2016.1254454

Levis, N. A., and Johnson, J. R. (2015). Level of UV-B radiation influences the effects of glyphosate-based herbicide on the spotted salamander. Ecotoxicology 24, 1073-1086. doi: 10.1007/s10646-015-1448-2

Li, M., Ruan, L. Y., Zhou, J. W., Fu, Y. H., Jiang, L., Zhao, H., et al. (2017). Metabolic profiling of goldfish (Carassius auratus) after longterm glyphosate-based herbicide exposure. Aquat. Toxicol. 188, 159-169. doi: 10.1016/j.aquatox.2017.05.004

Li, M.-H., Xu, H.-D., Liu, Y., Chen, T., Jiang, L., Fu, Y.-H., et al. (2016). Multi-tissue metabolic responses of goldfish (Carassius auratus) exposed to glyphosate-based herbicide. Toxicol. Res. 5, 1039-1052. doi: 10.1039/C6TX0 $0011 \mathrm{H}$ 
Li, Q., Lambrechts, M. J., Zhang, Q., Liu, S., Ge, D., Yin, R., et al. (2013). Glyphosate and AMPA inhibit cancer cell growth through inhibiting intracellular glycine synthesis. Drug Des. Dev. Ther. 24, 635-643. doi: 10.2147/DDDT. S49197

Lopes, F. M., Varela Junior, A. S., Corcini, C. D., da Silva, A. C., Guazzelli, V. G., Tavares, G., et al. (2014). Effect of glyphosate on the sperm quality of zebrafish Danio rerio. Aquat. Toxicol. 155, 322-326. doi: 10.1016/j.aquatox.2014.07.006

Lozano, V. L., Defarge, N., Rocque, L.-M., Mesnage, R., Hennequin, D., Cassier, R., et al. (2018). Sex-dependent impact of Roundup on the rat gut microbiome. Toxicol. Rep. 5, 96-107. doi: 10.1016/j.toxrep.2017.12.005

Luaces, J. P., Rossi, L. F., Chirino, M. G., Browne, M., Merani, M. S., and Mudry, M. D. (2017). Genotoxic effects of Roundup Full $\mathrm{II}^{\circledR}$ on lymphocytes of Chaetophractus villosus (Xenarthra, Mammalia): in vitro studies. PLoS ONE 12:e0182911. doi: 10.1371/journal.pone.0182911

Ludvigsen, G. H., and Lode, O. (2001). Results from "JOVA" the agricultural and environmental monitoring program of pesticides in Norway $1995-1999$. Fresenius Environ. Bull. 10, 470-474. Available online at: https://www.prtparlar.de/download_feb_2001/

Ludvigsen, G. H., and Lode, O. (2002). Trends in pesticides in Norwegian streams and rivers (1996-2000). Int. J. Environ. Anal. Chem. 82, 631-643. doi: $10.1080 / 0306731021000062982$

Luo, L., Wang, F., Zhang, Y., Zeng, M., Zhong, C., and Xiao, F. (2017). In vitro cytotoxicity assessment of roundup (glyphosate) in L-02 hepatocytes. J. Environ. Sci. Health B 52, 410-417. doi: 10.1080/03601234.2017.1293449

Lupi, L., Miglioranza, K. S., Aparicio, V. C., Marino, D., Bedmar, F., and Wunderlin, D. A. (2015). Occurrence of glyphosate and AMPA in an agricultural watershed from the southeastern region of Argentina. Sci. Total Environ. 536, 687-694. doi: 10.1016/j.scitotenv.2015.07.090

Lushchak, O. V., Kubrak, O. I., Storey, J. M., Storey, K. B., and Lushchak, V. I. (2009). Low toxic herbicide Roundup induces mild oxidative stress in goldfish tissues. Chemosphere 76, 932-937. doi: 10.1016/j.chemosphere.2009.04.045

MacBean, C. (2012). The Pesticide Manual, 16th Edn. Brighton: The British Crop Protection Council, 586-590.

Mahler, B. J., Van Metre, P. C., Burley, T. E., Loftin, K. A., Meyer, M. T., and Nowell, L. H. (2017). Similarities and differences in occurrence and temporal fluctuations in glyphosate and atrazine in small Midwestern streams (USA) during the 2013 growing season. Sci. Total Environ. 579, 149-158. doi: 10.1016/j.scitotenv.2016.10.236

Majewski, M. S., Coupe, R. H., Foreman, W. T., and Capel, P. D. (2014). Pesticides in Mississippi air and rain: a comparison between 1995 and 2007. Environ. Toxicol. Chem. 33, 1283-1293. doi: 10.1002/etc.2550

Mañas, F., Peralta, L., Raviolo, J., Ovando, H. G., Weyers, A., Ugnia, L., et al. (2009). Genotoxicity of AMPA, the environmental metabolite of glyphosate, assessed by the Comet assay and cytogenetic tests. Ecotox Environ. Saf. 72, 834-837. doi: 10.1016/j.ecoenv.2008.09.019

Mann, R. M., Hyne, R. V., Choung, C. B., and Wilson, S. P. (2009). Amphibians and agricultural chemicals: review of the risks in a complex environment. Environ. Pollut. 157, 2903-2927. doi: 10.1016/j.envpol.2009.05.015

Maqueda, C., Undabeytia, T., Villaverde, J., and Morillo, E. (2017). Behaviour of glyphosate in a reservoir and the surrounding agricultural soils. Sci. Total Environ. 593-594, 787-795. doi: 10.1016/j.scitotenv.2017.03.202

Marc, J., Mulner-Lorillon, O., and Bell,é, R. (2004). Glyphosatebased pesticides affect cell cycle regulation. Biol. Cell 96, 245-249. doi: 10.1016/j.biolcel.2003.11.010

Marc, J., Mulner-Lorillon, O., Boulben, S., Hureau, D., Durand, G., and Bellé, R. (2002). Pesticide Roundup provokes cell division dysfunction at the level of CDK1/cyclin B activation. Chem. Res. Toxicol. 15, 326-331. doi: $10.1021 / \mathrm{tx} 015543 \mathrm{~g}$

Mardiana-Jansar, K., and Ismail, B. S. (2014). Residue determination and levels of glyphosate in surface waters, sediments and soils associated with oil palm plantation in Tasik Chini, Pahang, Malaysia. AIP Conf. Proc. 1614, 795-802. doi: $10.1063 / 1.4895304$

Margaritopoulou, T., Tani, E., Chachalis, D., and Travlos, I. (2018). Involvement of epigenetic mechanisms in herbicide resistance: The Case of Conyza canadensis. Agriculture 8:17. doi: 10.3390/agriculture8010017

Markus, C., Pecinka, A., Karan, R., Barney, J. N., Merotto, A., and Jr. (2018). Epigenetic regulation - contribution to herbicide resistance in weeds? Pest Manag. Sci. 74, 275-281. doi: 10.1002/ps.4727
Marques, A., Guilherme, S., Gaivão, I., Santos, M. A., and Pacheco, M. (2014). Progression of DNA damage induced by a glyphosate-based herbicide in fish (Anguilla anguilla) upon exposure and post-exposure periods-insights into the mechanisms of genotoxicity and DNA repair. Comp. Biochem. Physiol. C 166, 126-133. doi: 10.1016/j.cbpc.2014.07.009

Martinez, D. A., Loening, U. E., and Graham, M. C. (2018). Impacts of glyphosatebased herbicides on disease resistance and health of crops: a review. Environ. Sci. Eur. 30:2. doi: 10.1186/s12302-018-0131-7

Martínez, M.-A., Ares, I., Rodríguez, J.-L., Martínez, M., Martínez-Larrañaga, M.-R., and Anadón, A. (2018). Neurotransmitter changes in rat brain regions following glyphosate exposure. Environ. Res. 161, 212-219. doi: 10.1016/j.envres.2017.10.051

Martini, C. N., Gabrielli, M., and VilaMdel, C. (2012). A commercial formulation of glyphosate inhibits proliferation and differentiation to adipocytes and induces apoptosis in 3T3-L1 fibroblasts. Toxicol. In Vitro 26, 1007-1013. doi: $10.1016 /$ j.tiv.2012.04.017

Martini, C. N., Gabrielli, M., Brandani, J. N., and Vila Mdel, C. (2016a). Glyphosate inhibits PPAR gamma induction and differentiation of Preadipocytes and is able to induce oxidative stress. J. Biochem. Mol. Biol. 30, 404-413. doi: $10.1002 /$ jbt.21804

Martini, C. N., Gabrielli, M., Codesido, M. M., and Vila, M. C. (2016b). Glyphosatebased herbicides with different adjuvants are more potent inhibitors of 3T3-L1 fibroblast proliferation and differentiation to adipocytes than glyphosate alone. Comp. Clin. Path 25, 607-613. doi: 10.1007/s00580-016-2238-9

Matozzo, V., Fabrello, J., Masiero, L., Ferraccio, F., Finosc, L., Pastore, P., et al. (2018). Ecotoxicological risk assessment for the herbicide glyphosate to nontarget aquatic species: a case study with the mussel Mytilus galloprovincialis. Environ. Pollut. 233, 623-632. doi: 10.1016/j.envpol.2017.10.100

McClellan, R. O. (2016). Evaluating the potential carcinogenic hazard of glyphosate. Crit. Rev. Toxicol. 46, 1-2. doi: 10.1080/10408444.2016.1234117

McDuffie, H. H., Pahwa, P., McLaughlin, J. R., Spinelli, J. J., Fincham, S., Dosman, J. A., et al. (2001). Non-Hodgkin's lymphoma and specific pesticide exposures in men: cross-Canada study of pesticides and health. Cancer Epidemiol. Biomarkers Prev. 10, 1155-1163. Available online at: http://cebp.aacrjournals. org/content/10/11/1155.full-text.pdf

McGuire, M. K., McGuire, M. A., Price, W. J., Shafii, B., Carrothers, J. M., Lackey, K. A., et al. (2016). Glyphosate and aminomethylphosphonic acid are not detectable in human milk. Am. J. Clin. Nutr. 103, 1285-1290. doi: $10.3945 /$ ajcn.115.126854

McKnight, U. S., Rasmussen, J. J., Kronvang, B., Binning, P. J., and Bjerg, P. L. (2015). Sources, occurrence and predicted aquatic impact of legacy and contemporary pesticides in streams. Environ. Pollut. 200, 64-76. doi: 10.1016/j.envpol.2015.02.015

McVey, K. A., Snapp, I. B., Johnson, M. B., Negga, R., Pressley, A. S., and Fitsanakis, V. A. (2016). Exposure of C. elegans eggs to a glyphosate-containing herbicide leads to abnormal neuronal morphology. Neurotoxicol. Teratol. 55, 23-31. doi: 10.1016/j.ntt.2016.03.002

Mendez, M. J., Aimar, S. B., Aparicio, V. C., Ramirez Haberkon, N. B., Buschiazzo, D. E., De Gerónimo, E., et al. (2017). Glyphosate and Aminomethylphosphonic acid (AMPA) contents in the respirable dust emitted by an agricultural soil of the central semiarid region of Argentina. Aeolian Res. 29, 23-29. doi: 10.1016/j.aeolia.2017.09.004

Menéndez-Helman, R. J., Miranda, L. A., Dos Santos Afonso, M., and Salibián, A. (2015). Subcellular energy balance of Odontesthes bonariensis exposed to a glyphosate-based herbicide. Ecotoxicol. Environ. Saf. 114, 157-163. doi: 10.1016/j.ecoenv.2015.01.014

Mensah, P. K., Palmer, C. G., and Odume, O. N. (2015). "Ecotoxicology of glyphosate and glyphosate-based herbicides - toxicity to wildlife and humans," in Toxicity and Hazard of Agrochemicals, eds M. L. Larramendy and S. Soloneski (Rijeka: InTech), 93-112

Mertens, M., Höss, S., Neumann, G., Afzal, J., and Reichenbecher, W. (2018). Glyphosate, a chelating agent-relevant for ecological risk assessment? Environ Sci Pollut Res. Int. 25, 5298-5317. doi: 10.1007/s11356-017-1080-1

Mesnage, R., and Antoniou, M. N. (2017). Facts and fallacies in the debate on glyphosate toxicity. Front. Public Health 5:316. doi: 10.3389/fpubh.2017.00316

Mesnage, R., and Antoniou, M. N. (2018). Ignoring adjuvant toxicity falsifies the safety profile of commercial pesticides. Front. Public Health 5:361. doi: 10.3389/fpubh.2017.00361 
Mesnage, R., Arno, M., Costanzo, M., Malatesta, M., Séralini, G. E., and Antoniou, M. N. (2015a). Transcriptome profile analysis reflects rat liver and kidney damage following chronic ultra-low dose Roundup exposure. Environ. Health 14:70. doi: 10.1186/s12940-015-0056-1

Mesnage, R., Bernav, B., and Séralini, G. E. (2013a). Ethoxylated adjuvants of glyphosate-based herbicides are active principles of human cell toxicity. Toxicol 313, 122-128. doi: 10.1016/j.tox.2012.09.006

Mesnage, R., Clair, E., Gress, S., Then, C., Székács, A., and Séralini, G.-E. (2013b). Cytotoxicity on human cells of CrylAb and CrylAc Bt insecticidal toxins alone or with a glyphosate-based herbicide. J. Appl. Toxicol. 33, 695-699. doi: $10.1002 /$ jat. 2712

Mesnage, R., Defarge, N., Spiroux de Vendômois, J., and Séralini, G. E. (2015b). Potential toxic effects of glyphosate and its commercial formulations below regulatory limits. Food Chem. Toxicol. 84, 133-153. doi: 10.1016/j.fct.2015.08.012

Mesnage, R., Defarge, N., Spiroux de Vendômois, J., and Séralini, G.-E. (2014). Major pesticides are more toxic to human cells than their declared active principles. Biomed. Res. Int. 2014:17969. doi: 10.1155/2014/179691

Mesnage, R., Moesch, C., Grand, R., Lauthier, G., Vendômois, J., Gress, S., et al. (2012). Glyphosate exposure in a farmer's family. J. Environ. Protect. 3, 1001-1003. doi: 10.4236/jep.2012.39115

Mesnage, R., Phedonos, A., Biserni, M., Arno, M., Balu, S., Corton, J. C., et al. (2017a). Evaluation of estrogen receptor alpha activation by glyphosate-based herbicide constituents. Food Chem. Toxicol. 108(Pt A):30-42. doi: 10.1016/j.fct.2017.07.025

Mesnage, R., Renney, G., Séralini, G. E., Ward, M., and Antoniou, M. N. (2017b). Multiomics reveal non-alcoholic fatty liver disease in rats following chronic exposure to an ultra-low dose of Roundup herbicide. Sci. Rep. 7:39328. doi: $10.1038 /$ srep39328

Meza-Joya, F. L., Ramírez-Pinilla, M. P., and Fuentes-Lorenzo, J. L. (2013). Toxic, cytotoxic, and genotoxic effects of a glyphosate formulation (Roundup ${ }^{\circledR} \mathrm{SL}-$ Cosmoflux $\left.{ }^{\circledR} 411 \mathrm{~F}\right)$ in the direct-developing frog Eleutherodactylus johnstonei. Environ. Mol. Mutagen. 54, 362-373. doi: 10.1002/em.21775

Miko, Z., Ujszegi, J., Gal, Z., and Hettyey, A. (2017a). Standardize or diversify experimental conditions in ecotoxicology? A case study on herbicide toxicity to larvae of two anuran amphibians. Arch. Environ. Contam. Toxicol. 73, 562-569. doi: 10.1007/s00244-017-0427-4

Mikó, Z., Ujszegi, J., Gál, Z., and Hettyey, A. (2017b). Effects of a glyphosatebased herbicide and predation threat on the behaviour of agile frog tadpoles. Ecotoxicol. Environ. Saf. 140, 96-102. doi: 10.1016/j.ecoenv.2017.02.032

Milan, M., Dalla Rovere, G., Smits, M., Ferraresso, S., Pastore, P., Marin, M. G., et al. (2018). Ecotoxicological effects of the herbicide glyphosate in non-target aquatic species: transcriptional responses in the mussel Mytilus galloprovincialis. Environ. Pollut. 237, 442-451. doi: 10.1016/j.envpol.2018.02.049

Mills, P. J., Kania-Korwel, I., and Fagan, J. (2017). Excretion of the herbicide glyphosate in older adults between 1993 and 2016. J. Am. Med. Assoc. 318, 1610-1611. doi: 10.1001/jama.2017.11726

Ministry of Agriculture and Rural Development Hungary (2009). Ministerial Decree 89/2004. (V. 15.) Ministry of Agriculture and Rural Development on the authorization and trade of pesticides, and their packaging, labeling, storage and transport (in Hungarian).

Modesto, K. A., and Martinez, C. B. R. (2010). Effects of Roundup transorb on fish: hematology, antioxidant defenses and acetylcholinesterase activity. Chemosphere 81, 781-787. doi: 10.1016/j.chemosphere.2010.07.005

Monroy, C. M., Cortés, A. C., Sicard, D. M., and de Restrepo, H. G. (2005). Cytotoxicity and genotoxicity in human cells exposed in vitro to glyphosate. Biomedica 25, 335-345. doi: 10.7705/biomedica.v25i3.1358

Monsanto Corp (2016). Monsanto's XtendiMax ${ }^{T M}$ herbicide with VaporGrip ${ }^{T M}$ Technology Approved by EPA for in-Crop Use. St. Louis, MO: Monsanto Company. Available online at: https://monsanto.com/news-releases/ monsantos-xtendimaxtm-herbicide-with-vaporgriptm-technologyapproved-by-epa-for-in-crop-use

Monte, T. C. de C, Garcia, J., Rosana, G., de Vasconcellos, M. C., Souza, J., Braga, B. V., et al. (2016). In vivo and in vitro effects of the herbicide Roundup $(\mathbb{R}$ on developmental stages of the trematode Echinostoma paraensei. Exp. Parasitol. 169, 43-50. doi: 10.1016/j.exppara.2016. 06.012
Moon, J. M., Chun, B. J., Cho, Y. S., Lee, S. D., Hong, Y. J., Shin, M. H., et al. (2018). Cardiovascular effects and fatality may differ according to the formulation of glyphosate salt herbicide. Cardiovasc Toxicol. 18, 99-107. doi: 10.1007/s12012-017-9418-y

Moreno, N. C., Sofia, S. H., and Martinez, C. B. (2014). Genotoxic effects of the herbicide Roundup Transorb and its active ingredient glyphosate on the fish Prochilodus lineatus. Environ. Toxicol. Pharmacol. 37, 448-454. doi: 10.1016/j.etap.2013.12.012

Mörtl, M., Németh, G. Y., Juracsek, J., Darvas, B., Kamp, L., and Rubio, F., Székács, A. (2013). Determination of glyphosate residues in Hungarian water samples by immunoassay. Microchem. J. 107, 143-151. doi: 10.1016/j.microc.2012.05.021

Mottier, A., Kientz-Bouchart, V., Serpentini, A., Lebel, J.-M., Jha, A. N., and Costil, K. (2013). Effects of glyphosate-based herbicides on embryo-larval development and metamorphosis in the Pacific oyster, Crassostrea gigas. Aquat. Toxicol. 128-129, 67-78. doi: 10.1016/j.aquatox.2012.12.002

Mottier, A., Pini, J., and Costil, K. (2014). Effects of a POEA surfactant system (Genamin T-200 ${ }^{\circledR}$ ) on two life stages of the Pacific oyster, Crassostrea gigas. J. Toxicol. Sci. 39, 211-215. doi: 10.2131/jts.39.211

Myers, J. P., Antoniou, M. N., Blumberg, B., Carroll, L., Colborn, T., Everett, L. G., et al. (2016). Concerns over use of glyphosate-based herbicides and risks associated with exposures: a consensus statement. Environ. Health 15:19. doi: 10.1186/s12940-016-0117-0

Nardemir, G., Agar, G., Arslan, E., and Erturk, F. A. (2015). Determination of genetic and epigenetic effects of glyphosate on Triticum aestivum with RAPD and CRED-RA techniques. Theor. Exp. Plant Physiol. 27, 131-139. doi: $10.1007 /$ s40626-015-0039-1

National Food Chain Safety Office (2016). The Authorization of Several Glyphosatebased Herbicides is Withdrawn. (in Hungarian). Budapest: National Food Chain Safety Office. Available online at: http://portal.nebih.gov.hu/-/szamos-glifozatkeszitmeny-engedelye-visszavonasra-kerul

Navarro, C. D., and Martinez, C. B. (2014). Effects of the surfactant polyoxyethylene amine (POEA) on genotoxic, biochemical and physiological parameters of the freshwater teleost Prochilodus lineatus. Comp. Biochem. Physiol. C 165, 83-90. doi: 10.1016/j.cbpc.2014.06.003

Nelsen, A. (2016). UN/WHO Panel in Conflict of Interest row Over Glyphosate Cancer risk. The Guardian 17.05.2016. Available online at: https://www. theguardian.com/environment/2016/may/17/unwho-panel-in-conflict-ofinterest-row-over-glyphosates-cancer-risk

Nevison, C. D. (2014). A comparison of temporal trends in United States autism prevalence to trends in suspected environmental factors. Environ. Health 13:73. doi: 10.1186/1476-069X-13-73

Newman, M. M., Hoilett, N., Lorenz, N., Dick, R. P., Liles, M. R., Ramsier, C., et al. (2016). Glyphosate effects on soil rhizosphereassociated bacterial communities. Sci. Total Environ. 543, 155-160. doi: 10.1016/j.scitotenv.2015.11.008

Nicolas, V., Oestreicher, N., and Vélot, C. (2016). Multiple effects of a commercial Roundup ${ }^{\circledR}$ formulation on the soil filamentous fungus Aspergillus nidulans at low doses: evidence of an unexpected impact on energetic metabolism. Environ. Sci. Pollut. Res. 23, 14393-14404. doi: 10.1007/s11356-016-6596-2

Nicolopoulou-Stamati, P., Maipas, S., Kotampasi, C., Stamatis, P., and Hens, L. (2016). Chemical pesticides and human health: the urgent need for a new concept in agriculture. Front. Public Health 4:148. doi: 10.3389/fpubh.2016.00148

Nielsen, L. N., Roager, H. M., Casas, M. E., Frandsen, H. L., Gosewinkel, U., Bester, K., et al. (2018). Glyphosate has limited short-term effects on commensal bacterial community composition in the gut environment due to sufficient aromatic amino acid levels. Environ. Pollut. 233, 364-376. doi: 10.1016/j.envpol.2017.10.016

Niemann, L., Sieke, C., Pfeil, R., and Solecki, R. (2015). A critical review of glyphosate findings in human urine samples and comparison with the exposure of operators and consumers. J. Verbr. Lebensm. 10, 3-12. doi: 10.1007/s00003-014-0927-3

Nivelle, E., Verzeaux, J., Chabot, A., Roger, D., Chesnais, Q., Ameline, A., et al. (2018). Effects of glyphosate application and nitrogen fertilization on the soil and the consequences on aboveground and belowground interactions. Geoderma 311, 45-57. doi: 10.1016/j.geoderma.2017.10.002

Nwani, C. D., Nagpure, N. S., Kumar, R., Kushwaha, B., and Lakra, W. S. (2013). DNA damage and oxidative stress modulatory effects of glyphosate-based 
herbicide in freshwater fish, Channa punctatus. Environ. Toxicol. Pharmacol. 36, 539-547. doi: 10.1016/j.etap.2013.06.001

Ockleford, C., Adriaanse, P., Berny, P., Brock, T., Duquesne, S., Grilli, S., et al. (2018). Scientific Opinion on the state of the science on pesticide risk assessment for amphibians and reptiles. EFSA J. 16:5125. doi: $10.2903 /$ j.efsa.2018.5125

Ørsted, M., and Roslev, P. (2015). A fluorescence-based hydrolytic enzyme activity assay for quantifying toxic effects of Roundup ${ }^{\circledR}$ to Daphnia magna. Environ. Toxicol. Chem. 34, 1841-1850. doi: 10.1002/etc.2997

Owagboriaye, F. O., Dedeke, G. A., Ademolu, K. O., Olujimi, O. O., Ashidi, J. S., and Adeyinka, A. A. (2017). Reproductive toxicity of Roundup herbicide exposure in male albino rat. Exp. Toxicol. Pathol. 69, 461-468. doi: 10.1016/j.etp.2017.04.007

Paganelli, A., Gnazzo, V., Acosta, H., López, S. L., and Carrasco, A. E. (2010). Glyphosate-based herbicides produce teratogenic effects on vertebrates by impairing retionic acid signaling. Chem. Res. Toxicol. 23, 1586-1595. doi: $10.1021 /$ tx 1001749

Pandolfo, C. E., Presotto, A., Carbonell, F. T., Ureta, S., Poverene, M., and Cantamutto, M. (2018). Transgene escape and persistence in an agroecosystem: the case of glyphosate-resistant Brassica rapa L. in central Argentina. Environ. Sci. Pollut. Res. Int. 25, 6251-6264. doi: 10.1007/s11356-0170726-3

Parvez, S., Gerona, R. R., Proctor, C., Friesen, M., Ashby, J. L., Reiter, J. L., et al. (2018). Glyphosate exposure in pregnancy and shortened gestational length: a prospective Indiana birth cohort study. Environ. Health 17:23. doi: 10.1186/s12940-018-0367-0

Paumgartten, F. J. P. (2017). Glyphosate exposure, cardiovascular diseases and cancer risks. J. Public Health Emerg. 1:15. doi: 10.21037/jphe.2016.12.17

Payne, N. J. (1992). Off-target glyphosate from aerial silvicultural applications and buffer zones required around sensitive areas. Pestic. Sci. 34, 1-8. doi: $10.1002 /$ ps.2780340102

Payne, N. J., Feng, J. C., and Reynolds, P. E. (1990). Off-target deposits and buffer zones required around water for aerial glyphosate applications. Pestic. Sci. 30, 183-198. doi: 10.1002/ps.2780300206

Perego, M. C., Caloni, F., Cortinovis, C., Schutz, L. F., Albonico, M., Tsuzukibashi, D., et al. (2017). Influence of a Roundup formulation on glyphosate effects on steroidogenesis and proliferation of bovine granulosa cells in vitro. Chemosphere 188, 274-279. doi: 10.1016/j.chemosphere.2017.09.007

Pérez, D. J., Okada, E., De Gerónimo, E., Menone, M. L., Aparicio, V. C., and Costa, J. L. (2017). Spatial and temporal trends and flow dynamics of glyphosate and other pesticides within an agricultural watershed in Argentina. Environ. Toxicol. Chem. 36, 3206-3216. doi: 10.1002/etc.3897

Perez, G. L., Vera, M. S., and Miranda, L. A. (2011). "Effects of herbicide glyphosate and glyphosate-based formulations on aquatic ecosystems," in Herbicides and Environment, ed A. Kortekamp (Rijeka: InTech), 343-368.

Pérez-Torres, I., Zuniga-Munoz, A. M., and Guarner-Lans, V. (2017). Beneficial effects of the amino acid glycine. Mini-Rev. Med. Chem. 17, 15-32. doi: 10.2174/1389557516666160609081602

Perry, E. D., Ciliberto, F., Hennessy, D. A., and Moschini, G. C. (2016). Genetically engineered crops and pesticide use in U.S. maize and soybeans. Sci. Adv. 2:e1600850. doi: 10.1126/sciadv.1600850

Persch, T. S. P., da Silva, P. R., dos Santos, S. H. D., de Freitas, B. S., and Oliveira, G. T. (2018). Changes in intermediate metabolism and oxidative balance parameters in sexually matured three-barbeled catfishes exposed to herbicides from rice crops (Roundup ${ }^{\circledR}$, Primoleo ${ }^{\circledR}$ and Facet ${ }^{\circledR}$ ). Environ. Toxicol. Pharmacol. 58, 170-179. doi: 10.1016/j.etap.2018.01.004

Peruzzo, P. J., Porta, A. A., and Ronco, A. E. (2008). Levels of glyphosate in surface waters, sediments and soils associated with direct sowing soybean cultivation in north pampasic region of Argentina. Environ. Pollut. 156, 61-66. doi: $10.1016 /$ j.envpol.2008.01.015

Pesticide Action Network and Use of science in EU risk assessment (2018). Pesticide Action Network and Use of Science in EU Risk Assessment. Available online at: http://www.pan-europe.info/eu-legislation/legislationplant-protection-products/use-science-eu-risk-assessment

Pinto, E., Soares, A. G., and Ferreira, I. P. M. L.V. (2018). Quantitative analysis of glyphosate, glufosinate and AMPA in irrigation water by in situ derivatization - dispersive liquid-liquid microextraction combined with UPLC-MS/MS. Anal. Methods 10, 554-561. doi: 10.1039/C7AY02722B
Poiger, T., Buerge, I. J., Bächli, A., Müller, M. D., and Balmer, M. E. (2017). Occurrence of the herbicide glyphosate and its metabolite AMPA in surface waters in Switzerland determined with on-line solid phase extraction LC-MS/MS. Environ. Sci. Pollut. Res. 24, 1588-1596. doi: 10.1007/s11356-016-7835-2

Poirier, F., Boursier, C., Mesnage, R., Oestreicher, N., Nicolas, V., and Vélot, C. (2017). Proteomic analysis of the soil filamentous fungus Aspergillus nidulans exposed to a Roundup formulation at a dose causing no macroscopic effect: a functional study. Environ. Sci. Pollut. Res. 24, 25933-25946. doi: 10.1007/s11356-017-0217-6

Popp, M., Hann, S., Mentler, A., Fuerhacker, M., Stingeder, G., and Koellensperger, G. (2008). Determination of glyphosate and AMPA in surface and waste water using high-performance ion chromatography coupled to inductively coupled plasma dynamic reaction cell mass spectrometry (HPIC-ICP-DRC-MS). Anal. Bioanal. Chem. 391, 695-699. doi: 10.1007/s00216-008-2037-5

Portier, C. J., and Clausing, P., Re: Tarazona et al. (2017). Glyphosate Toxicity and Carcinogenicity: a Review of the Scientific Basis of the European Union Assessment and its Differences With IARC.

Portier, C. J., Armstrong, B. K., Baguley, B. C., Baur, X., Belyaev, I., Bellé, R., et al. (2016). Differences in the carcinogenic evaluation of glyphosate between the International Agency for Research on Cancer and the European Food Safety Authority. J Epidemiol. Commun. Health 70, 741-745. doi: 10.1136/jech-2015-207005

Primost, J. E., Marino, D. J. G., Aparicio, V. C., Costa, J. L., and Carriquiriborde, P. (2017). Glyphosate and AMPA, "pseudo-persistent" pollutants under real-world agricultural management practices in the Mesopotamic Pampas agroecosystem, Argentina. Environ. Pollut. 229, 771-779. doi: 10.1016/j.envpol.2017.06.006

Prosser, R., Rodriguez-Gil, J. L., Solomon, K. R., Sibley, P. K., and Poirier, D. G. (2017). Effects of the herbicide surfactant MON 0818 on oviposition and viability of eggs of the ramshorn snail (Planorbella pilsbryi). Environ. Toxicol. Chem. 36, 522-531. doi: 10.1002/etc.3571

Qin, Y., Li, X., Xiang, Y., Wu, D., Bai, L., Li, Z., et al. (2017). Toxic effects of glyphosate on diploid and triploid fin cell lines from Misgurnus anguillicaudatus. Chemosphere 180, 356-364. doi: 10.1016/j.chemosphere.2017.03.098

Ramwell, C. T., Heather, A. I. J., and Shepherd, A. J. (2002). Herbicide loss following application to a roadside. Pest Manage Sci. 58, 695-701. doi: 10.1002/ps.506

Ramwell, C. T., Kah, M., and Johnson, P. D. (2014). Contribution of household herbicide usage to glyphosate and its degradate aminomethylphosphonic acid in surface water drains. Pest Manage. Sci. 70, 1823-1830. doi: 10.1002/ps.3724

Relyea, R. A., and Jones, D. K. (2009). The toxicity of Roundup Original MAX ${ }^{\circledR}$ to 13 species of larval amphibians. Environ. Toxicol. Chem. 28, 2004-2008. doi: 10.1897/09-021.1

Rendón-von Osten, J., and Dzul-Caamal, R. (2017). Glyphosate residues in groundwater, drinking water and urine of subsistence farmers from intensive agriculture localities: a survey in Hopelchén, Campeche, Mexico. Int. J. Environ. Res. Public Health 14:595. doi: 10.3390/ijerph14060595

Richard, S., Moslemi, S., Sipahutar, H., Benachour, N., and Séralini, G.-E. (2005). Differential effects of glyphosate and Roundup on human placental cells and aromatase. Environ. Health Perspect. 113, 716-720. doi: 10.1289/ehp.7728

Richard, S., Prévot-D'Alvise, N., Bunet, R., Simide, R., Couvray, S., Coupé, S., et al. (2014). Effect of a glyphosate-based herbicide on gene expressions of the cytokines interleukin- $1 \beta$ and interleukin-10 and of heme oxygenase- 1 in European sea bass, Dicentrarchus labrax L. Bull. Environ. Contam. Toxicol. 92, 294-299. doi: 10.1007/s00128-013-1180-7

Richards, B. K., Pacenka, S., Meyer, M. T., Dietze, J. E., Schatz, A. L., Teuffer, K., et al. (2018). Antecedent and post-application rain events trigger glyphosate transport from runoff-prone soils. Environ. Sci. Technol. Lett. 5, 249-254. doi: 10.1021/acs.estlett.8b00085

Rissoli, R. Z., Abdalla, F. C., Costa, M. J., Rantin, F. T., McKenzie, D. J., and Kalinin, A. L. (2016). Effects of glyphosate and the glyphosate based herbicides Roundup Original ${ }^{\circledR}$ and Roundup Transorb ${ }^{\circledR}$ on respiratory morphophysiology of bullfrog tadpoles. Chemosphere 156, 37-44. doi: 10.1016/j.chemosphere.2016.04.083

Rocha, T. L., dos Santos, A. P., Yamada, Á. T., Soares, C. M., Borges, C. L., Bailão, A. M., et al. (2015). Proteomic and histopathological 
response in the gills of Poecilia reticulata exposed to glyphosate-based herbicide. Environ. Toxicol. Pharmacol. 40, 175-186. doi: 10.1016/j.etap.2015. 04.016

Rodriguez-Gil, J. L., Prosser, R., Hanta, G., Poirier, D., Lissemore, L., Hanson, M., et al. (2017b). Aquatic hazard assessment of MON 0818, a commercial mixture of alkylamine ethoxylates commonly used in glyphosate-containing herbicide formulations. Part 2: Roles of sediment, temperature, and capacity for recovery following a pulsed exposure. Environ. Toxicol. Chem. 36, 512-521. doi: 10.1002/etc.3558

Rodriguez-Gil, J. L., Prosser, R., Poirier, D., Lissemore, L., Thompson, D., Hanson, M., et al. (2017a). Aquatic hazard assessment of MON 0818, a commercial mixture of alkylamine ethoxylates commonly used in glyphosatecontaining herbicide formulations. Part 1: Species sensitivity distribution from laboratory acute exposures. Environ. Toxicol. Chem. 36, 501-511. doi: 10.1002/ etc.3559

Romano, M. A., Romano, R. M., Santos, L. D., Wisniewski, P., Campos, D. A., de Souza, P. B., et al. (2012). Glyphosate impairs male offspring reproductive development by disrupting gonadotropin expression. Arch. Toxicol. 86, 663-673. doi: 10.1007/s00204-011-0788-9

Romano, R. M., Romano, M. A., Bernardi, M. M., Furtado, P. V., and Oliveira, C. A. (2010). Prepubertal exposure to commercial formulation of the herbicide glyphosate alters testosterone levels and testicular morphology. Arch. Toxicol. 84, 309-317. doi: 10.1007/s00204-009-0494-z

Ronco, A. E., Marino, D. J. G., Abelando, M., Almada, P., and Apartin, C. D. (2016). Water quality of the main tributaries of the Paraná Basin: glyphosate and AMPA in surface water and bottom sediments. Environ. Monitor Assess 188:458. doi: 10.1007/s10661-016-5467-0

Rossi, L. F., Luaces, J. P., Palermo, A. M., Merani, M. S., and Mudry, M. D. (2018). Cytogenetic damage in peripheral blood cultures of Chaetophractus villosus exposed in vivo to a glyphosate formulation (Roundup). Ecotoxicol. Environ. Saf. 157, 121-127. doi: 10.1016/j.ecoenv.2018.03.046

Roustan, A., Aye, M., De Meo, M., and Di Giorgio, C. (2014). Genotoxicity of mixtures of glyphosate and atrazine and their environmental transformation products before and after photoactivation. Chemosphere 108, 93-100. doi: $10.1016 /$ j.chemosphere.2014.02.079

Rubio, F., Guo, E., and Kamp, L. (2014). Survey of glyphosate residues in honey, corn and soy products. J. Environ. Anal. Toxicol. 5:249. doi: 10.4172/2161-0525.1000249

Ruiz-Toledo, J., Castro, R., Rivero-Pérez, N., Bello-Mendoza, R., and Sánchez, D. (2014). Occurrence of glyphosate in water bodies derived from intensive agriculture in a tropical region of Southern Mexico. Bull. Environ. Contam. Toxicol. 93, 289-293. doi: 10.1007/s00128-014-1328-0

Sánchez, J. A., Varela, A. S. Jr., Corcini, C. D., da Silva, J. C., Primel, E. G., Caldas, S., et al. (2017). Effects of Roundup formulations on biochemical biomarkers and male sperm quality of the livebearing Jenynsia multidentata. Chemosphere 177, 200-210. doi: 10.1016/j.chemosphere.2017.02.147

Sanchís, J., Kantiani, L., Llorca, M., Rubio, F., Ginebreda, A., Fraile, J., et al. (2012). Determination of glyphosate in groundwater samples using an ultrasensitive immunoassay and confirmation by on-line solid-phase extraction followed by liquid chromatography coupled to tandem mass spectrometry. Anal. Bioanal. Chem. 402, 2335-2345. doi: 10.1007/s00216-011-5541-y

Saracci, R. (2016). The hazads of Hazard Identification. In Old and New Risks: Challenges for Environmental Epidemiology. Available online at: https://ehp. niehs.nih.gov/isee/isee-2016

Saunders, L. E., and Pezeshki, R. (2015). Glyphosate in runoff waters and in the root-zone: a review. Toxics 3, 462-480. doi: 10.3390/toxics3040462

Schinasi, L., and Leon, M. E. (2014). Non-Hodgkin lymphoma and occupational exposure to agricultural pesticide chemical groups and active ingredients: a systematic review and meta-analysis. Int. J. Environ. Res. Public Health 11, 4449-4527. doi: 10.3390/ijerph110404449

Schütte, G. M., Eckerstorfer, M., Rastelli, V., Reichenbecher, W., Restrepo-Vassalli, S., et al. Mertens, M. (2017). Herbicide resistance and biodiversity: agronomic and environmental aspects of genetically modified herbicide-resistant plants. Environ. Sci. Eur. 29:5. doi: 10.1186/s12302-016-0100-y

Séguin, A., Mottier, A., Perron, C., Lebel, J. M., Serpentini, A., and Costil, K. (2017). Sub-lethal effects of a glyphosate-based commercial formulation and adjuvants on juvenile oysters (Crassostrea gigas) exposed for 35 days. Mar. Pollut. Bull. 117(1-2):348-358. doi: 10.1016/j.marpolbul.2017.02.028
Seok, S.-J., Park, J.-S., Hong, J.-R., Gil, H.-W., Yang, J.-O., Lee, E.-Y., et al. (2011). Surfactant volume is an essential element in human toxicity in acute glyphosate herbicide intoxication. Clin. Toxicol. 49, 892-899. doi: 10.3109/15563650.2011.626422

Séralini, G.-E., Clair, E., Mesnage, R., Gress, S., Defarge, N., Malatesta, M., et al. (2014). Republished study: long-term toxicity of a Roundup herbicide and a Roundup-tolerant genetically modified maize. Environ. Sci. Eur. 26:14. doi: 10.1186/s12302-014-0014-5

Shiogiri, N. S., Paulino, M. G., Carraschi, S. P., Baraldi, F. G., da Cruz, C., and Fernandes, M. N. (2012). Acute exposure of a glyphosate-based herbicide affects the gills and liver of the Neotropical fish, Piaractus mesopotamicus. Environ. Toxicol. Pharmacol. 34, 388-396. doi: 10.1016/j.etap.2012.05.007

Shipitalo, M. J., and Owens, L. B. (2011). Comparative losses of glyphosate and selected residual herbicides in surface runoff from conservation-tilled watersheds planted with corn or soybean. J. Environ. Qual. 40, 1281-1289. doi: $10.2134 /$ jeq 2010.0454

Silva, V., Montanarella, L., Jones, A., Fernández-Ugalde, O., Mol, H. G. J., Ritsema, C. J., et al. (2018). Distribution of glyphosate and aminomethylphosphonic acid (AMPA) in agricultural topsoils of the European Union. Sci. Total Environ. 621, 1352-1359. doi: 10.1016/j.scitotenv.2017.10.093

Singh, K. D., Faridi, S. H., and Lodhi, M. (2017). Possible mechanisms of development of carcinoma of breast in patients with early-onset cataract. Int. Surg. J. 4, 1394-1397. doi: 10.18203/2349-2902.isj20171149

Sinhorin, V. D. G., Sinhorin, A. P., Teixeira, J. M., dos Santos Miléski, K. M. L., Hansen, P. C., Moreira, P. S. A., et al. (2014). Effects of the acute exposition to glyphosate-based herbicide on oxidative stress parameters and antioxidant responses in a hybrid Amazon fish surubim (Pseudoplatystoma sp). Ecotox Environ. Safe 106, 181-187. doi: 10.1016/j.ecoenv.2014.04.040

Siroski, P. A., Poletta, G. L., Latorre, M. A., Merchant, M. E., Ortega, H. H., and Mudry, M. D. (2016). Immunotoxicity of commercial-mixed glyphosate in broad snouted caiman (Caiman latirostris). Chem. Biol. Interact. 244, 64-70. doi: $10.1016 /$ j.cbi.2015.11.031

Skark, C., Zullei-Seibert, N., Schottler, U., and Schlett, C. (1998). The occurrence of glyphosate in surface water. Int. J. Environ. Anal. Chem. 70:93104. doi: $10.1080 / 03067319808032607$

Skeff, W., Neumann, C., and Schulz-Bull, D. (2015). Glyphosate and AMPA in the estuaries of the Baltic Sea method optimization and field study. Mar. Pollut. Bull. 100, 577-585. doi: 10.1016/j.marpolbul.2015.08.015

Slomberg, D. L., Ollivier, P., Radakovitch, O., Baran, N., Sani-Kast, N., Bruchet, A., et al. (2017). Insights into natural organic matter and pesticide characterisation and distribution in the Rhone River. Environ. Chem. 14, 64-73. doi: 10.1071/EN16038

Smedbol, É., Gomes, M. P., Paquet, S., Labrecque, M., Lepage, L., Lucotte, M., et al. (2018). Effects of low concentrations of glyphosate-based herbicide factor $540^{\circledR}$ on an agricultural stream freshwater phytoplankton community. Chemosphere 192, 133-141. doi: 10.1016/j.chemosphere.2017.10.128

Smedbol, É., Lucotte, M., Labrecque, M., Lepage, L., and Juneau, P. (2017). Phytoplankton growth and PSII efficiency sensitivity to a glyphosate-based herbicide (Factor $540^{\circledR}$ ). Aquat. Toxicol. 192, 265-273. doi: 10.1016/j.aquatox.2017.09.021

Solomon, K. R. (2016). Glyphosate in the general population and in applicators: a critical review of studies on exposures. Crit. Rev. Toxicol. 46, 21-27. doi: 10.1080/10408444.2016.1214678

Soloneski, S., de Arcaute, C. R., and Larramendy, M. L. (2016). Genotoxic effect of a binary mixture of dicamba- and glyphosate-based commercial herbicide formulations on Rhinella arenarum (Hensel, 1867) (Anura, Bufonidae) late-stage larvae. Environ. Sci. Pollut. Res. 23, 17811-17821. doi: 10.1007/s11356-016-6992-7

Song, H.-Y., Kim, Y.-H., Seok, S.-J., Gil, H.-W., and Hong, S.-Y. (2012). In vitro cytotoxic effect of glyphosate mixture containing surfactants. J. Korean Med. Sci. 27, 711-715. doi: 10.3346/jkms.2012.27.7.711

Soracco, C. G., Villarreal, R., Lozano, L. A., Vittori, S., Melani, E. M., and Marino, D. J. G. (2018). Glyphosate dynamics in a soil under conventional and no-till systems during a soybean growing season. Geoderma 323, 13-21. doi: 10.1016/j.geoderma.2018.02.041

Soso, A. B., Barcellos, L. J. G., Ranzani-Paiva, M. J., Kreutz, L. C., Quevedo, R. M., Anziliero, D., et al. (2007). Chronic exposure to sublethal concentration of a glyphosate-based herbicide alters hormone 
profiles and affects reproduction of female Jundiá (Rhamdia quelen). Environ. Toxicol. Pharmacol. 23, 308-313. doi: 10.1016/j.etap.2006. 11.008

Steinborn, A., Alder, L., Michalski, B., Zomer, P., Bendig, P., Martinez, S. A., et al. (2016). Determination of glyphosate levels in breast milk samples from Germany by LC-MS/MS and GC-MS/MS. J. Agric. Food Chem. 64, 1414-1421. doi: 10.1021 /acs.jafc.5b05852

Stephenson, C. L., Harris, C. A., and Clarke, R. (2018). An assessment of the acute dietary exposure to glyphosate using deterministic and probabilistic methods. Food Addit. Contam A- 35, 258-272.

Struger, J., Thompson, D., Staznik, B., Martin, P., McDaniel, T., and Marvin, C. (2008). Occurrence of glyphosate in surface waters of Southern Ontario. Bull. Environ. Contam. Toxicol. 80, 378-384. doi: 10.1007/s00128-008-9373-1

Sulukan, E., Köktürk, M., Ceylan, H., Beydemir, S., Ișik, M., Atamanalp, M., et al. (2017). An approach to clarify the effect mechanism of glyphosate on body malformations during embryonic development of zebrafish (Danio rerio). Chemosphere 180, 77-85. doi: 10.1016/j.chemosphere.2017.04.018

Swanson, N. L., Leu, A., Abrahamson, J., and Wallet, B. (2014). Genetically engineered crops, glyphosate and the deterioration of health in the United States of America. J. Org. Syst. 9, 6-37. Available online at: http:// www.organic-systems.org/journal/92/JOS_Volume-9_Number-2_Nov_2014Swanson-et-al.pdf

Székács, A. (2017). Mechanism-related teratogenic, hormone modulant and other toxicological effects of veterinary and agricultural surfactants. Insigths Vet Sci. 1, 24-31. doi: 10.29328/journal.hvsr.1001003

Székács, A., and Darvas, B. (2012). "Forty years with glyphosate," in Herbicides Properties, Synthesis and Control of Weeds, ed M. N. Hasaneen, (Rijeka: InTech), $247-284$.

Székács, A., Mörtl, M., and Darvas, B. (2015). Monitoring pesticide residues in surface and ground water in Hungary: Surveys in 1990-2015. J. Chem. 2015:717948.

Székács, I., Fejes, Á., Klátyik Sz, Takács, E., Patk,ó, D., Pomóthy, J., Mörtl, M., et al. (2014). Environmental and toxicological impacts of glyphosate with its formulating adjuvant. Int. J. Biol. Biomol. Agric. Food Biotech. Eng. 8, 219-224. Available online at: https://waset.org/publications/9997659/environmentaland-toxicological-impacts-of-glyphosate-with-its-formulating-adjuvant

Tang, J., Hu, P., Li, Y., Win-Shwe, T. T., and Li, C. (2017). Ion imbalance is involved in the mechanisms of liver oxidative damage in rats exposed to glyphosate. Front Physiol 8:01083. doi: 10.3389/fphys.2017.01083

Tarazona, J. V., Court-Marques, D., Tiramani, M., Reich, H., Pfeil, R., Istace, F., et al. (2017a). Glyphosate toxicity and carcinogenicity: a review of the scientific basis of the European Union assessment and its differences with IARC. Arch. Toxicol. 91, 2723-2743. doi: 10.1007/s00204-017-1962-5

Tarazona, J. V., Court-Marques, D., Tiramani, M., Reich, H., Pfeil, R., Istace, F., et al. (2017b). Response to the reply by C. J. Portier and P. Clausing, concerning our review "Glyphosate toxicity and carcinogenicity: a review of the scientific basis of the European Union assessment and its differences with IARC". Arch. Toxicol. 91, 3199-3203. doi: 10.1007/s00204-017-2 032-8

Tarone, R. E. (2018). On the International Agency for Research on Cancer classification of glyphosate as a probable human carcinogen. Eur. J. Cancer Prev. 27, 82-87. doi: 10.1097/CEJ.00000000000 00289

Thongprakaisang, S., Thiantanawat, A., Rangkadilok, N., Suriyo, T., and Satayavivad, J. (2013). Glyphosate induces human breast cancer cells growth via estrogen receptors. Food Chem. Toxicol. 59, 129-136. doi: 10.1016/j.fct.2013.05.057

Torretta, V., Katsoyiannis, I. A., Viotti, P., and Rada, E. C. (2018). Critical review of the effects of glyphosate exposure to the environment and humans through the food supply chain. Sustainability 10:950. doi: 10.3390/su10040950

Townsend, M., Peck, C., Meng, W., Heaton, M., Robison, R., and O'Neill, K. (2017). Evaluation of various glyphosate concentrations on DNA damage in human Raji cells and its impact on cytotoxicity. Regul. Toxicol. Pharmacol. 85, 79-85. doi: 10.1016/j.yrtph.2017.02.002

Transparency Market Research (2014). Glyphosate Market for Genetically Modified and Conventional Crops - Global Industry Analysis, Size, Share, Growth, Trends and Forecast 2013-2019. Albany: Transparency
Market Research Available from: http://www.transparencymarketresearch. com/glyphosate-market.html

Transparency Market Research (2016). Global Glyphosate Market to Reach US\$8.79 bn by 2019 Propelled by Increasing Adoption of Genetically Modified Crops. Albany: Transparency Market Research Available from: http://www. transparencymarketresearch.com/pressrelease/glyphosate-market.htm

Ugarte, R. (2014). Interaction between glyphosate and mitochondrial succinate dehydrogenase. Comput. Theor. Chem. 1043, 54-63. doi: $10.1016 /$ j.comptc.2014.05.018

Ujszegi, J., Gál, Z., Mikó, Z., and Hettyey, A. (2015). No observable effect of a glyphosate-based herbicide on two top predators of temporal water bodies. Environ. Toxicol. Chem. 34, 307-313. doi: 10.1002/etc.2798

Ujszegi, J., Gál, Z., Mikó, Z., and Hettyey, A. (2016). No effect of a glyphosate-based herbicide on larval dragonflies (Aeshna cyanea) and adult newts (Lissotriton vulgaris) in a laboratory-based experiment. Acta Zool Acad. Sci. Hung 62, 355-367. doi: 10.17109/AZH.62.4.355.2016

United States Environmental Protection Agency (2003). Occurrence Estimation Methodology and Occurrence Findings Report for the Six-Year Review of Existing National Primary Drinking Water Regulations, US EPA Report No. EPA-815-R-03-006. Washington, DC: US EPA Available online at: https://www. epa.gov/sites/production/files/2014-12/documents/815r03006.pdf

United States Environmental Protection Agency (2015). Evaluation of the Carcinogenic Potential of Glyphosate. Washington DC p. 1-87. Available online at: https://www.acsh.org/wp-content/uploads/2016/05/EPA-glyphosatedocument-final.pdf

United States Environmental Protection Agency (2016a). Reregistration Eligibility Decision (RED) Glyphosate. Washington DC: US EPA p. 1-290. Available online at: https://nepis.epa.gov/Exe/ZyPDF.cgi/901A0500.PDF?Dockey= 901A0500.PDF

United States Environmental Protection Agency (2016b). Glyphosate Issue Paper: Evaluation of Carcinogenic Potential. Washington DC p. 1-227. Available online at: https://www.epa.gov/sites/production/files/2016-09/documents/ glyphosate_issue_paper_evaluation_of_carcincogenic_potential.pdf

Uren Webster, T. M., and Santos, E. M. (2015). Global transcriptomic profiling demonstrates induction of oxidative stress and of compensatory cellular stress responses in brown trout exposed to glyphosate and Roundup. BMC Genomics 16:32. doi: 10.1186/s12864-015-1254-5

Uren Webster, T. M., Laing, L. V., Florance, H., and Santos, E. M. (2014). Effects of glyphosate and its formulation, Roundup, on reproduction in zebrafish (Danio rerio). Environ. Sci. Technol. 48, 1271-1279. doi: 10.1021/es40 $4258 \mathrm{~h}$

Url, B. (2018). Don't attack science agencies for political gain. Nature 553:381. doi: 10.1038/d41586-018-01071-9

Van Bruggen, A. H. C., He, M. M., Shin, K., Mai, V., Jeong, K. C., Finckh, M. R., et al. (2018). Environmental and health effects of the herbicide glyphosate. Sci. Total Environ. 616-617, 255-268. doi: 10.1016/j.scitotenv.2017.1 0.309

Van Stempvoort, D. R., Spoelstra, J., Senger, N. D., Brown, S. J., Post, R., and Struger, J. (2016). Glyphosate residues in rural groundwater, Nottawasaga RiverWatershed, Ontario, Canada. Pest Manage Sci. 72, 1862-1072. doi: $10.1002 /$ ps. 4218

Vandenberg, L. N., Blumberg, B., Antoniou, M. N., Benbrook, C. M., Carroll, L., Colborn, T., et al. (2017). Is it time to reassess current safety standards for glyphosate-based herbicides? J. Epidemiol. Commun. Health 71, 613-618. doi: 10.1136/jech-2016-208463

Vandenberg, L. N., Colborn, T., Hayes, T. B., Heindel, J. J., Jacobs, D. R. Jr. Lee, D. H., et al. (2012). Hormones and endocrine disrupting chemicals: lowdose effects and nonmonotonic dose responses. Endocr. Rev. 33, 378-455. doi: 10.1210/er.2011-1050

Varayoud, J., Durando, M., Ramos, J. G., Milesi, M. M., Ingaramo, P. I., Muñoz-de-Toro, M., et al. (2017). Effects of a glyphosate-based herbicide on the uterus of adult ovariectomized rats. Environ. Toxicol. 32, 1191-1201. doi: $10.1002 /$ tox.22316

Vera, M. S., Lagomarsino, L., Sylvester, M., Pérez, G. L., Rodriguez, P., Mugni, H., et al. (2010). New evidence of Roundup (glyphosate formulation) impact on periphyton community and the water quality of freshwater ecosystems. Ecotoxicology 19, 710-721. doi: 10.1007/s10646-009-0446-7 
Villeneuve, A., Larroudé, S., and Humbert, J. F. (2011). "Herbicide contamination of freshwater ecosystems: impact on microbial communities," in Pesticides - Formulations, Effects, Fate, eds M. Stoytcheva (Rijeka:InTech), 285-312.

Wagner, N., Reichenberger, W., Teichmann, H., Tappeser, B., and Lötters, S. (2013). Questions concerning the potential impact of glyphosatebased herbicides on amphibians. Environ. Toxicol. Chem. 32, 1688-1700. doi: $10.1002 /$ etc. 2268

Wang, C., Lin, X., Li, L., Lin, L. X., and Lin, S. (2017). Glyphosate shapes a dinoflagellate-associated bacterial community while supporting algal growth as sole phosphorus source. Front. Microbiol. 8:2530. doi: $10.3389 /$ fmicb.2017.02530

Williams, G. M., Aardema, M., Acquavella, J., Berry, C., Brusick, D., Burns, M. M., et al. (2016a). A review of the carcinogenic potential of glyphosate by four independent expert panels and comparison to the IARC assessment. Crit. Rev. Toxicol. 46(Supp.1), 3-20. doi: 10.1080/10408444.2016.1214677

Williams, G. M., Berry, C., Burns, M., de Camargo, J. L. V., and Greim, H. (2016b). Glyphosate rodent carcinogenicity bioassay expert panel review. Crit. Rev. Toxicol. 46, 44-55. doi: 10.1080/10408444.2016.1214679

Williams, G. M., Kroes, R., and Munro, I. C. (2000). Safety evaluation and risk assessment of the herbicide roundup and its active ingredient, glyphosate, for humans. Regul Toxicol Pharmacol 31, 117-165. doi: 10.1006/rtph.1999.1371

Xu, J., Li, G., Wang, Z., Si, L., He, S., Cai, J., et al. (2016). The role of Ltype amino acid transporters in the uptake of glyphosate across mammalian epithelial tissues. Chemosphere 145, 487-494. doi: 10.1016/j.chemosphere.2015. 11.062

Xu, Y., Li, A. J., Li, K., Qin, J., and Li, H. (2017). Effects of glyphosate-based herbicides on survival, development and growth of invasive snail (Pomacea canaliculata). Aquat. Toxicol. 193, 136-143. doi: 10.1016/j.aquatox.2017.10.011

Yadav, S. S., Giri, S., Singha, U., Boro, F., and Giri, A. (2013). Toxic and genotoxic effects of Roundup on tadpoles of the Indian skittering frog (Euflictis cyanophlyctis) in the presence and absence of predator stress. Aquat. Toxicol. 132-133, 1-8. doi: 10.1016/j.aquatox.2013.01.016

Young, F., Ho, D., Glynn, D., and Edwards, V. (2015). Endocrine disruption and cytotoxicity of glyphosate androundup in human JAr cells in vitro. Integr. Pharm. Toxicol. Gentocicol. 1, 12-19. doi: 10.15761/IPTG.1000114

Yusof, S., Ismail, A., and Alias, M. S. (2014). Effect of glyphosate-based herbicide on early life stages of Java medaka (Oryzias javanicus): a potential tropical test fish. Mar. Pollut. Bull. 85, 494-498. doi: 10.1016/j.marpolbul.2014.03.022
Zaller, J. G., Heigl, F., Ruess, L., and Grabmaier, A. (2014). Glyphosate herbicide affects belowground interactions between earthworms and symbiotic mycorrhizal fungi in a model ecosystem. Sci. Rep. 4:5634. doi: $10.1038 /$ srep05634

Zaruk, D. (2016). Goodbye Glyphosate: Why Science Doesn't Matter in the Age of Stupid. Available from: https://risk-monger.com/about-2

Zebral, Y. D., Lansini, L. R., Costa, P. G., Roza, M., Bianchini, A., and Robaldo, R. B. (2018). A glyphosate-based herbicide reduces fertility, embryonic upper thermal tolerance and alters embryonic diapause of the threatened annual fish Austrolebias nigrofasciatus. Chemosphere 196, 260-269. doi: 10.1016/j.chemosphere.2017.12.196

Zhong, G., Wu, Z., Yin, J., and Chai, L. (2018). Responses of Hydrilla verticillata (L.f.) Royle and Vallisneria natans (Lour.) Hara to glyphosate exposure. Chemosphere 193, 385-393. doi: 10.1016/j.chemosphere.2017.10.173

Zyoud, S. H., Waring, W. S., Al-Jabi, S. W., and Sweileh, W. M. (2017). Global research production in glyphosate intoxication from 1978 to 2015: a bibliometric analysis. Hum. Exp. Toxicol. 36, 997-1006. doi: $10.1177 / 0960327116678299$

Disclamier: AS is member of the Management Board of the European Food Safety Authority (EFSA) and of the Scientific Advisory Body of the Co-operative Research Programmes (CRP) of the Organisation for Economic Co-operation and Development (OECD). This publication reflects the views of the Authors, it does not necessarily reflect the view of these organizations, and EFSA and OECD cannot be held responsible for any use which may be made of the information contained therein.

Conflict of Interest Statement: The authors declare that the research was conducted in the absence of any commercial or financial relationships that could be construed as a potential conflict of interest.

The reviewer MA and handling editor declared their shared affiliation.

Copyright $(\odot 2018$ Székács and Darvas. This is an open-access article distributed under the terms of the Creative Commons Attribution License (CC BY). The use, distribution or reproduction in other forums is permitted, provided the original author(s) and the copyright owner(s) are credited and that the original publication in this journal is cited, in accordance with accepted academic practice. No use, distribution or reproduction is permitted which does not comply with these terms. 